\title{
The postmenopausal ovary : functional and morphological aspects
}

Citation for published version (APA):

Sluijmer, A. V. (1999). The postmenopausal ovary : functional and morphological aspects. [Doctoral Thesis, Maastricht University]. Universiteit Maastricht. https://doi.org/10.26481/dis.19990702as

Document status and date:

Published: 01/01/1999

DOI:

10.26481/dis.19990702as

Document Version:

Publisher's PDF, also known as Version of record

\section{Please check the document version of this publication:}

- A submitted manuscript is the version of the article upon submission and before peer-review. There can be important differences between the submitted version and the official published version of record.

People interested in the research are advised to contact the author for the final version of the publication, or visit the DOI to the publisher's website.

- The final author version and the galley proof are versions of the publication after peer review.

- The final published version features the final layout of the paper including the volume, issue and page numbers.

Link to publication

\footnotetext{
General rights rights.

- You may freely distribute the URL identifying the publication in the public portal. please follow below link for the End User Agreement:

www.umlib.nl/taverne-license

Take down policy

If you believe that this document breaches copyright please contact us at:

repository@maastrichtuniversity.nl

providing details and we will investigate your claim.
}

Copyright and moral rights for the publications made accessible in the public portal are retained by the authors and/or other copyright owners and it is a condition of accessing publications that users recognise and abide by the legal requirements associated with these

- Users may download and print one copy of any publication from the public portal for the purpose of private study or research.

- You may not further distribute the material or use it for any profit-making activity or commercial gain

If the publication is distributed under the terms of Article $25 \mathrm{fa}$ of the Dutch Copyright Act, indicated by the "Taverne" license above, 


\section{THE POSTMENOPAUSAL OVARY}

\section{FUNCTIONAL AND MORPHOLOGICAL ASPECTS}


Prof. dr. J.L.H. Evers

Prof. dr. M.J. Heineman

(Rijksuniversiteit Groningen)

Prof. dr. F.H. de Jong

(Erasmus Universiteit Rotterdam)

Beoordelingscommissie:

Prof. dr. T.W.A. de Bruin (voorzitter)

Prof. dr. J.G. Aalders

(Rijksuniversiteit Groningen)

Prof. dr. J.W. Arends

Prof. dr. J. Schoemaker (Vrije Universiteit Amsterdam)

Prof. dr. G.J. van der Vusse 


\title{
THE POSTMENOPAUSAL OVARY
}

\section{FUNCTIONAL AND MORPHOLOGICAL ASPECTS}

\author{
Proefschrift
}

\author{
ter verkrijging van de graad van doctor \\ aan de Universiteit Maastricht, \\ op gezag van de Rector Magnificus, \\ Prof. Dr. A.C. Nieuwenhuijzen Kruseman \\ in het openbaar te verdedigen op \\ vrijdag 2 juli 1999 om 12.00 uur
}

door

ALEXANDER VICTOR SLUIJMER

geboren op 23 juni 1959

te Apeldoorn 


\section{CIP-GEGEVENS KONINKLIJKE BIBLIOTHEEK, DEN HAAG}

Sluijmer, Alexander Victor

The postmenopausal ovary. Functional and morphological aspects/ Alexander Victor Sluijmer.-[S.1.:s.n.]. -I11.

Proefschrift Maastricht.-Met lit.opg.-Met samenvatting in het Nederlands ISBN 90-9012802-6

Drukkerij: Stichting Drukkerij C. Regenboog, Groningen.

The generous supply of the GnRHa triptorelin (Decapeptyl) and the financial support by Ferring B.V. Haarlem as well as the technical and scientifical support by Organon International B.V. Oss is gratefully acknowledged. 
Ook bij de behandeling van vrouwen met climacterische klachten kunnen oestrogenen desgewenscht door testosteron vervangen worden. In gevallen waar hooge doses testosteron moeten worden gegeven, is gebleken dat testosteron een krachtig aphrodisiacum is voor de vrouw. Het wordt dan ook in gevallen van frigiditeit met succes toegepast.

Dr. E. Laqueur, et al (Amsterdam, 1948).

Uit: Hormonologie. Physiologie en pharmacologie van de hormonen. 


\section{CONTENTS}

ABBREVIATIONS

VOORWOORD

\section{CHAPTER 1}

General introduction

\section{CHAPTER 2}

\section{Section I}

Utero-ovarian vein blood sampling in postmenopausal women

Fertil Steril 1993;60:184-6

\section{Section II}

Peripheral vein, ovarian vein and ovarian tissue levels of inhibin in a postmenopausal patient with a granulosa cell tumour Acta Endocrinol 1993;129:311-4

\section{CHAPTER 3}

Pituitary down-regulation with a single depot-dose of a GnRH agonist (Triptorelin) in postmenopausal women

Maturitas 1994;20:45-51

\section{CHAPTER 4}

\section{Section I}

Endocrine activity of the postmenopausal ovary: the effects of pituitary downregulation and oophorectomy $J$ Clin Endocrinol Metab 1995;80:2163-7

\section{Section II}

Effect of chronological age and time after menopause on ovarian vein levels of testosterone and androstenedione in postmenopausal women

\section{CHAPTER 5}

Relationship between ovarian production of estrone, estradiol, testosterone, and androstenedione and the ovarian degree of stromal hyperplasia in postmenopausal women.

Menopause 1998;5:207-10

\section{CHAPTER 6}

A study of the presence and expression of $\mathrm{LH}, \mathrm{FSH}$ and GnRH receptors in human postmenopausal ovaries 


\section{CHAPTER 7}

General discussion

SUMMARY

SAMENVATTING 101

CURRICULUM VITAE 105 ADDENDUM 1 . 107 ADDENDUM 2. 


\section{ABBREVIATIONS}
A
androstenedione
CIN
cervical intra-epithelial neoplasia
DHEAS
dehydroepiandrosterone sulfate
D-TRP ${ }^{6} \mathrm{GnRH}$
D-triptorelin ${ }^{6}$ gonadotrophin-releasing hormone
E1
oestrone
E2
17ß-oestradiol

FSH

follicle-stimulating hormone

$\mathrm{GnRH}$

gonadotrophin-releasing hormone

GnRHa

gonadotrophin-releasing hormone agonist

hCG

human chorionic gonadotrophin

HE

hematoxylin and eosin

hFSH

human follicle-stimulating hormone

hLH

human luteinizing hormone

IgM

immunoglobulin $\mathrm{M}$

(I) $\mathrm{U}$

(international) unit

LH

luteinizing hormone

mRNA

messenger ribonucleic acid

$\mathrm{n}$

$\operatorname{nano}\left(10^{-9}\right)$

$\operatorname{pico}\left(10^{-12}\right)$

$\mathrm{p}$

probability value (significance level) obtained

from a hypothesis test

RIA

radio-immuno assay

SD

standard deviation

SEM

standard error of the mean

SHBG

sex hormone-binding globulin

$\mathrm{T}$

testosterone

$\mu$

$\operatorname{micro}\left(10^{-6}\right)$ 
Het is af! Bijna 10 jaar ben ik met dit proefschrift bezig geweest in een proces van (weinig) hollen en (veel) stilstaan. Toch ben ik trots en blij dat ik het afgemaakt heb. Hierbij heeft zeker een gevoel van verplichting jegens de enorme inzet van anderen een rol gespeeld.

Dit proefschrift is tot stand gekomen door nauwe samenwerking tussen de afdelingen Gynaecologie van het (voormalig) De Wever-Ziekenhuis te Heerlen en het Academisch Ziekenhuis te Maastricht en de afdeling Endocrinologie en Voortplanting van de Erasmus Universiteit te Rotterdam. Het moge iedereen duidelijk zijn dat het schrijven van een proefschrift alleen mogelijk is met de hulp van velen. Zonder anderen te kort te willen doen, bedank ik toch enkele personen met name:

* Hooggeleerde Evers, Hans, bedankt dat je het nooit opgegeven hebt. Bij het inleveren van een nieuw hoofdstuk liet jij elke keer weer weten blij verrast te zijn en kreeg ik het meestal per omgaande perfect gecorrigeerd weer terug. Je kennis van de Engelse taal is overigens fenomenaal.

* Hooggeleerde Heineman, Maas Jan, het idee van dit proefschrift is van jou afkomstig. Jij bent daarom ook de drijvende kracht achter dit onderzoek geweest. Jouw eeuwig enthousiasme en optimisme heeft mij gestimuleerd het vol te houden tot het einde. Hulde!

Hooggeleerde de Jong, Frank, fantastisch hoe jij je laboratorium beschikbaar hebt gesteld voor mijn onderzoek. Alles was altijd mogelijk! Daarnaast hebben je vele correcties en ideeën mij enorm geholpen. Toch blijf ik volhouden dat HST voor Hormoon Substitutie Therapie staat en niet voor Hoge Snelheids Trein.

Zeergeleerde Koudstaal, Johan en zeergeleerde Theunissen, Paul, bedankt voor het zeer nauwkeurig bekijken en scoren van de vele coupes.

Zeergeleerde de Leeuw, Renato, bedankt voor het beschikbaar stellen van je laboratorium voor de gonadotrofinen bepalingen en het aandragen van ideeën met betrekking tot het receptor-onderzoek.

* Zeergeleerde Grootenhuis, Arijan, alhoewel we elkaar nog nooit ontmoet hebben aarzelde je niet om mij te helpen bij het bewerken van gegevens voor het hoofdstuk over de receptoren. Bedankt!

Mevrouw Tolenaars, Gerda, het was heel aardig van je om buiten kantooruren materiaal te snijden en te kleuren. Ik vond deze sessies bere gezellig. 
Hooggeleerde leden van de beoordelingscommissie, bedankt voor de vlotte toetsing van het manuscript.

(Zeer)geleerde (ex)leden van de Maatschap Gynaecologie en Verloskunde van het (tegenwoordig) Atrium Medisch Centrum te Heerlen/ Brunssum; J.E.M. Degen, T.H.B. Salemans, J.E.G.M. Stoot, J.H.M. Ubachs, J.A. Zandvoort, bedankt voor het getoonde vertrouwen in mijn onderzoek en het trouw aanmelden van geschikte patiënten.

Lieve Marion, Eva en Geke. Ik ben veel te vaak voor jullie niet beschikbaar geweest alhoewel ik sterk de neiging heb dit te bagatelliseren. De nu beschikbare tijd zal voor jullie zijn. Het is absoluut waar Marion, dat het belachelijk is dat iedereen het badinerend heeft over "het boekje" maar dat dit boekje niets meer of minder is dan een levenswerk. 


\section{CHAPTER 1}

\section{GENERAL INTRODUCTION}


The ovary is a dynamic organ. During a lifetime it undergoes many changes both of function and morphology. Short term changes take place within one menstrual cycle, long term changes occur in the course of the various episodes of life.

The lifetime of an ovary starts during the embryonic stage of the female individual -when germinal cells migrate to the gonadal folds- and progresses from early childhood through the fertile years of life to the postmenopausal period. Menarche (first menstrual bleeding) and menopause (last menstrual bleeding) are critical markers in the lifetime of ovarian function. Block (1) and Baker (2) have shown that after a steep initial increase of the number of oocytes to 7,5 million by mitotic replication of primordial germ cells and differentiation into oogonia, the number of oocytes in the ovary sharply decreases already during foetal life. At birth a girl will have around 2 million oocytes left, by the age of seven years, the number has been further reduced to 300,000 .

The ovary and the dynamics of the ovarian cycle during fertile life have been studied extensively. Much less is known about the ovarian changes after the menopause.

\section{Morphology of the postmenopausal ovary}

In 1944, Hertig (3) described the changing nature of ovarian morphology and argued that the aging of the ovary continues throughout life and is not completed at the moment of menopause.

During the reproductive stage of life the volume of the ovary is largely determined by the number and size of the antral follicles. With the menopause approaching, the number of follicles sharply decreases. This is accompanied by a decrease in cortical thickness. As a result, the gyrated aspect of the ovarian cortex becomes increasingly more pronounced (4). As age advances, a growing number of corpora fibrosa and corpora albicantia can be discerned in the ovary. Late in life, the remainder of these can still be detected.

From a recent study (5) of the number of follicles in the ovaries it appeared that the average number of primordial follicles in regularly menstruating, climacteric women was ten times as high as among climacteric women already menstruating irregularly (1392 \pm 355 versus $142 \pm 72$ ). Virtually no follicles were found in postmenopausal women.

The size of the postmenopausal ovary has been studied by Goswamy et al. (6). In 2246 women the volume of the postmenopausal ovary was examined using ultrasound scans. It was established that the ovarian size diminishes with increasing postmenopausal age. Furthermore, the size of the postmenopausal ovary was shown to be subject to significant interindividual differences.

The size of the postmenopausal ovary is determined foremost by cortical thickness and stromal volume. There is a distinction between the atrophic ovary on the one hand, characterized by a thin cortex and scanty stroma, and the ovary with an increased stromal volume on the other, referred to as stromal hyperplasia. 
Ovarian stromal (hyper)activity has been linked to the existence of endometrial carcinoma since the early 30 's (7). Later, also breast cancer was assumed to be related to the stromal activity of the ovary (8). Woll and co-workers were the first to put forward the hypothesis that the ovarian stroma produces steroids affecting the endometrium (9). Histochemical investigations were performed to identify the presence of enzyme activity necessary for the production of steroids in ovarian stroma $(10,11)$. The extent of stromal hyperplasia is probably correlated with the postmenopausal ovarian steroid production as recorded in the literature $(12,13)$.

\section{Function of the postmenopausal ovary}

Postmenopausal oestrogen production results predominantly from the extraglandular conversion of androstenedione to oestrone (14-16). This conversion takes place mainly in fat tissue, so body weight is of prime importance in the oestrogen production after the menopause $(17,18)$.

Already in the sixties and seventies, studies were performed to find out whether the postmenopausal ovary still produces hormones and, if so, which hormones. The results of these studies, however, contradict each other due to the use of different research methods (Table 1). Some studies investigated peripheral (antecubital vein) hormone levels, occasionally in combination with measurements prior to, during and after oophorectomy (19-23). Other studies focused on the peripheral and ovarian venous hormone levels without considering the effect of oophorectomy (24-28). Also, studies have been performed measuring the plasma production rates of androgens and/or oestrogens, sometimes in combination with conversion rates and metabolic clearance rates $(15,29)$. Even in vitro studies using radioactive precursors have been used to investigate the function of the postmenopausal ovary (30).

A number of studies has suggested that postmenopausal ovaries produce oestrone and oestradiol (25-27), yet most research has reached the conclusion that postmenopausal ovaries only produce a small amount of oestradiol $(15,20-22,24,29,31)$ and that the oestradiol in the circulation is mainly generated through the peripheral conversion of oestrone and testosterone (32).

The views on androgen production by postmenopausal ovaries are virtually unanimous. The production of both testosterone and androstenedione has been documented $(24,27,33)$. Some researchers regard testosterone as the quantitatively most significant steroid produced by the postmenopausal ovary, a status others reserve for androstenedione (25).

Several studies have looked into the factors determining the ovarian steroid production by the postmenopausal ovary. Here again, however, the results are conflicting. In some studies an increase in ovarian steroid production was found after the administration of hCG $(21,34)$. A significant decrease in testosterone after administering goserelin (a gonadotrophin releasing hormone $[\mathrm{GnRH}]$ agonist) to patients with breast 
Table 1. Review of the literature concerning postmenopausal ovarian production of oestrone (E1), oestradiol (E2), androstenedione (A), and testosterone (T).

\begin{tabular}{ll}
\hline & $\begin{array}{c}\text { Ovarian vs peripheral vein ser } \\
\text { levels }\end{array}$ \\
\hline Mattingly et al (1969 [30]) & \\
Rader et al (1973 [19]) $\quad E 1=; E 2=$ \\
Judd et al (1974 [24]) & $\begin{array}{l}E 1 \uparrow(P<0.05) ; E 2 \uparrow(P<0.05) \\
\text { A }(\mathrm{ns}) ; T \uparrow(P<0.01)\end{array}$
\end{tabular}

Judd et al (1974 [20])

$T \downarrow(P<0.001) ; A \downarrow(P<0.001)$

Greenblatt et al (1976 [25])

$E 2=$

$\mathrm{A} \uparrow(\mathrm{ns}): \pi \uparrow(\mathrm{ns})$

Vermeulen et al (1976 [26])

Judd et al (1976 [22])

before vs after $\infty$ phorectomy before vs after $\infty$ ophorectomy

in vitro studies

(one group of patients)

(diff. groups of patients)

$A$ and $T$ production

Dennefors et al (1980 [32])

$E 1=; E 2=$

$A \downarrow(P<0.01): T \downarrow(P<0.01)$

$E 1=; E 2=$

$$
\begin{array}{ll}
\text { Longcope et al (1980[26]) } & E 1=; E 2 \uparrow(s ?) \\
& A=; T \uparrow(s ?) \\
\text { Lucisano et al (1984 [27]) } & E 1 \uparrow(P<0.01) ; E 2 \uparrow(P<0.001) \\
& A \uparrow(P<0.01) ; T \uparrow(P<0.001) \\
\text { Aiman et al (1986 [28]) } & E 1=; E 2 \uparrow(s ?) \\
& A=; T \uparrow(s ?)
\end{array}
$$

ns = not significant ; s? = significance unknown 
cancer was established by Dowsett et al. (33). In other studies steroid levels were found to be unaffected by the administration of a GnRH agonist $(35,36)$.

LH and FSH act on specific cells in the ovaries. LH stimulates theca and granulosa cells, whereas FSH stimulates granulosa cells. LH and FSH consist of a common $\alpha-$ subunit and a hormone specific B-subunit both of which are glycosylated (37). The Bsubunit is the major determinant of the hormone specificity of receptor binding. The hormones $\mathrm{LH}$ and FSH act on the gonads through binding to receptors located on the surface of specific target cells, followed by activation of intracellular second messenger systems and cellular responses (38). In the preovulatory phase of the menstrual cycle LH stimulates ovarian theca cells, whereas FSH stimulates ovarian granulosa cells. GnRH is released from the hypothalamus and binds to a specific receptor on the cell membrane of the pituitary gonadotroph, resulting in stimulation of FSH and LH biosynthesis and release (39). GnRH binding has also been reported in extrapituitary tissues, e.g. the ovary $(40,41)$. Binding sites and expression of receptor activity for $\mathrm{LH}, \mathrm{FSH}$, and GnRH have been found in premenopausal human ovarian tissue (42-48). Little is known about the presence of LH and FSH receptors in peri- and postmenopausal ovaries (49-51). No information is available on the expression and functional activity of GnRH receptors in postmenopausal ovaries.

\section{Objectives and approaches of this study}

Although much has been written about medical problems in women caused by their perimenopausal state, for which hormone replacement therapy would be required, data on the function of the postmenopausal ovary itself are lacking. The aim of the present study was to gain insight in the function of the postmenopausal ovary and its relationship with morphology.

The following questions served as starting points:

1. Does postmenopausal ovarian hormonal activity exist?

2. If so, to which degree is this activity related to ovarian morphology?

3. Do gonadotrophins still have a regulatory effect on this presumed postmenopausal ovarian activity?

4. Can gonadotrophin receptors be detected in the postmenopausal ovary?

In this study, postmenopausal women were included, who for various reasons underwent uni- or bilateral oophorectomy with or without hysterectomy between 1 January 1990 and 1 January 1992 in the De Wever \& Gregorius hospital in Heerlen, the Netherlands. A study protocol was developed and approval was obtained from the Hospital Ethics Committee to conduct the investigation. For the patients an informative brochure was written (addendum 1), which included a form to give informed consent. The inclusion criteria were as follows: no oestrogen replacement therapy for at least six months prior to the investigation, last menstrual period at least twelve months before the start of the study, and at least one ovary present at the time of surgery. 
This study was a collaborative project between the The Wever \& Gregorius Hospital, Heerlen, Maastricht University Hospital, Maastricht, and the Erasmus University, Rotterdam, The Netherlands.

Technical and scientific support was received from the Organon Research Laboratories, Oss, The Netherlands. Financial support and supplementation of the GnRHa triptorelin was received from Ferring B.V., Haarlem, The Netherlands.

The results of this study are presented in the next chapters:

In chapter 2 (section I), the method of ovarian vein blood sampling used in our study will be described.

In chapter 2 (section II), the validity of our method of ovarian vein blood sampling will be illustrated in a patient with a unilateral granulosa cell carcinoma of the ovary and increased inhibin concentrations.

No studies have been published in which the effects of the administration of a single depot-dose of a GnRHa to postmenopausal women have been described. We will report the effects on gonadotrophin release after the administration of a single depotdose of a GnRHa to postmenopausal women in chapter 3.

In chapter 4 (section I), the results will be presented of a study on the endocrine activity of the postmenopausal ovary by measuring peripheral vein hormone levels before, during, and after oophorectomy together with measuring ovarian vein hormone levels during operation. In order to determine whether gonadotrophins still have a regulatory effect on this activity, the effects of pituitary down-regulation on these hormone levels were studied as well.

In chapter 4 (section II), the effects of chronological age and time after menopause on ovarian vein levels of $\mathrm{T}$ and $\mathrm{A}$ will be described. The group of patients which was not treated with a GnRHa in chapter 4 (section I) was used for this study. The degree to which ovarian activity is related to ovarian morphology will be investigated by studying the relationship between ovarian production of individual hormones and the degree of stromal hyperplasia in the postmenopausal ovary. The findings will be described in chapter 5.

Since the activity of the postmenopausal ovary appeared to be gonadotrophindependent, the presence of gonadotrophin- and GnRH-receptors in the postmenopausal ovary was studied. The results of this investigation will be described in chapter 6 .

The results of the presented investigations and the interrelationship of our findings will be discussed in chapter 7 . In this conclusive chapter the original questions pertaining to postmenopausal ovarian function will be answered and suggestions for future research will be done. 


\section{References}

1. Block E. Quantitative morphological investigations of the follicular system in women. Acta Anat 1952;14:108-23.

2. Baker TG. A quantitative and cytological study of germ cells in human ovaries. Proc R Soc Lond [Biol] 1963;158: 417-33.

3. Hertig AT. The aging ovary: a preliminary note. J Clin Endocrinol 1944;4:581-2.

4. Clement PB. Histology of the ovary. Am J Surg Pathol 1987;11:277-303.

5. Richardson SJ, Senikas V, Nelson JF. Follicular depletion during the menopausal transition: Evidence for accelerated loss and ultimate exhaustion. J Clin Endocrinol Metab 1987;65:1231-7.

6. Goswamy RK, Campbell S, Royston JP, Bhan V, Battersby RH, Hall VJ, Whitehead MI, Collins WP. Ovarian size in postmenopausal women. Br J Obstet Gynaecol 1988;95:795-801.

7. Smith GVS. Carcinoma of the endometrium: a review with results of treatment through 1935. N Engl J Med 1941; 225:608-15.

8. Sommers SC, Teloh HA. Ovarian stromal hyperplasia in breast cancer. Arch Path 1952;53:160-6.

9. Woll E, Hertig AT, Smith GVS, Johnson LC. The ovary in endometrial carcinoma: with notes on the morphological history of the aging ovary. Am J Obstet Gynecol 1948;56:617-33.

10. Novak ER, Goldberg B, Jones GS, O'Toole RV. Enzyme histochemistry of the menopausal ovary associated with normal and abnormal endometrium. Am J Obstet Gynecol 1965;93:669-82.

11. Fienberg R. The stromal theca cell and postmenopausal endometrial adenocarcinoma. Cancer $1969 ; 24: 32-8$.

12. Boss JH, Scully RE, Wegner KH, Cohen RB. Structural variations in the adult ovary: clinical significance. Obstet Gynecol 1965;25:747-64.

13. Lucisano A, Russo N, Acampora MG, Fabiano A, Fattibene M, Parlati E, Maniccia E, Dell'Acqua $\mathrm{S}$. Ovarian and peripheral androgen and oestrogen levels in postmenopausal women: correlations with ovarian histology. Maturitas 1986;8:57-65.

14. Meldrum DR, Davidson BJ, Tataryn IV, Judd HL. Changes in circulating steroids with aging in postmenopausal women. Obstet Gynecol 1981;57:624-8.

15. Grodin JM, Siiteri PK, MacDonald PC. Source of estrogen production in postmenopausal women. J Clin Endocrinol Metab 1973;36:207-14.

16. MacDonald PC, Siiteri PK. The relationship between the extraglandular production of estrone and the occurrence of endometrial neoplasia. Gynecol Oncol 1974;2:259-63.

17. MacDonald PC, Edman CD, Hemsell DL, Porter JC, Siiteri PK. Effect of obesity on conversion of plasma androstenedione to estrone in postmenopausal women with and without endometrial cancer. Am J Obstet Gynecol 1978;130:448-55. 
18. Vermeulen A, Verdonck L. Sex hormone concentrations in postmenopausal women: relation to obesity, fat mass, age and years postmenopause. Clin Endocrinol 1978;9:59-66.

19. Rader MD, Flickinger GL, de Villa GO, Mikuta JJ, Mikhail G. Plasma estrogens in postmenopausal women. Am J Obstet Gynecol 1973;116:1069-73.

20. Judd HL, Lucas WE, Yen SSC. Effect of oophorectomy on circulating testosterone and androstenedione levels in patients with endometrial cancer. Am J Obstet Gynecol 1974;118:793-8.

21. Vermeulen A. The hormonal activity of the postmenopausal ovary. J Clin Endocrinol Metab 1976;42:247-53.

22. Judd HL, Lucas WE, Yen SSC. Serum 17B-estradiol and estrone levels in postmenopausal women with and without endometrial cancer. J Clin Endocrinol Metab 1976;43:272-8.

23. Chakravarti S, Collins WP, Forecast JD, Newton JR, Oram DH, Studd JWW. Hormonal profiles after the menopause. Br Med J 1976;2:784-7.

24. Judd HL, Judd GE, Lucas WE, Yen SSC. Endocrine function of the postmenopausal ovary: concentration of androgens and estrogens in ovarian and peripheral vein blood. J Clin Endocrinol Metab 1974;39:1020-4.

25. Greenblatt RB, Colle ML, Mahesh VB. Ovarian and adrenal steroid production in the postmenopausal women. Obstet Gynecol 1976;47:383-7.

26. Longcope C, Hunter R, Franz C. Steroid secretion by the postmenopausal ovary. Am J Obstet Gynecol 1980;138:564-8.

27. Lucisano A, Acampora MG, Russo N, Maniccia E, Montemurro A, Dell'Acqua S. Ovarian and peripheral plasma levels of progestogens, androgens and oestrogens in postmenopausal women. Maturitas 1984;6:45-53.

28. Aiman J, Forney JP, Parker CR. Secretion of androgens and estrogens by normal and neoplastic ovaries in postmenopausal women. Obstet Gynecol 1986;68:1-5.

29. Longcope C. Metabolic clearance and blood production rates of estrogens in postmenopausal women. Am J Obstet Gynecol 1971;111:778-81.

30. Mattingly RF, Huang WY. Steroidogenesis of the menopausal and postmenopausal ovary. Am J Obstet Gynecol 1969;103:679-93.

31. Dennefors BL, Janson PO, Knutson F, Hamberger L. Steroid production and responsiveness to gonadotropin in isolated stromal tissue of human postmenopausal ovaries. Am J Obstet Gynecol 1980;136:997-1002.

32. Siiteri PK. Postmenopausal estrogen production. In: van Keep PA, Lauritzen C, eds. Front Hormone Res (Karger,Basel) 1975;3:40-5.

33. Dowsett M, Cantwell B, Lal A, Jeffcoate SL, Harris AL. Suppression of postmenopausal ovarian steroidogenesis with the luteinizing hormone-releasing hormone agonist goserelin. J Clin Endocrinol Metab 1988;66:672-7. 
34. Poliak A, Jones GES, Goldberg B, Solomon D, Woodruff JD. Effect of human chorionic gonadotropin on postmenopaual women. Am J Obstet Gynecol 1968;101:731-9.

35. Plowman PN, Nicholson RI, Walker KJ. Remission of postmenopausal breast cancer during treatment with the luteinising hormone releasing hormone agonist ICI 118630. Br J Cancer 1986;54:903-9.

36. Waxman JH, Harland SJ, Coombes RC, Wrigley PFM, Malpas JS, Powles T, Lister TA. The treatment of postmenopausal women with advanced breast cancer with buserelin. Cancer Chemother Pharmacol 1985;15:171-3.

37. Gharib SD, Wierman ME, Shupnik MA, Chin WW. Molecular biology of the pituitary gonadotropins. Endocr Rev 1990; 11:177-99.

38. Leung PCK, Steele GL. Intracellular signaling in the gonads. Endocr Rev 1992;13:476-98.

39. Conn PM, Crowley Jr WF. Gonadotropin-releasing hormone and its analogues. N Engl J Med 1991;324:93-103.

40. Hsueh AJW, Erickson GF. Extrapituitary action of gonadotropin-releasing hormone: direct nhibition of ovarian steroidogenesis. Science 1979;204:854-5.

41. Knecht M, Ranta T, Feng P, Shinohara O, Catt KJ. Gonadotropin-releasing hormone as a modulator of ovarian function. J Steroid Biochem 1985;23:771-8.

42. Rao ChV, Griffin LP, Carman Jr FR. Gonadotropin receptors in human corpora lutea of the menstrual cycle and pregnancy. Am J Obstet Gynecol 1977;128:146-53.

43. Rajaniemi HJ, Rönnberg L, Kauppila A, Ylöstalo P, Jalkanen M, Saastamoinen J, Selander K, Pystynen P, Vihko R. Luteinizing hormone receptors in human ovarian follicles and corpora lutea during menstrual cycle and pregnancy. J Clin Endocrinol Metab 1981;108:307-13.

44. Shima K, Kitayama S, Nakano R. Gonadotropin binding sites in human ovarian follicles and corpora lutea during the menstrual cycle. Obstet Gynecol 1987;69:800-6.

45. Minaretzis D, Jakubowski M, Mortola JF, Pavlou SN. Gonadotropin-releasing hormone receptor gene expression in human ovary and granulosa-lutein cells. J Clin Endocrinol Metab 1995;80:4304.

46. Peng C, Fan NC, Ligier M, Väänänen J, Leung PCK. Expression and regulation of gonadotropinreleasing hormone $(\mathrm{GnRH})$ and $\mathrm{GnRH}$ receptor messenger ribonucleic acids in human granulosaluteal cells. Endocrinology 1994;135:1740-6.

47. Minegishi T, Tano M, Abe Y, Nakamura K, Ibuki Y, Miyamoto K. Expression of luteinizing hormone/ human chorionic gonadotrophin (LH/HCG) receptor mRNA in the human ovary. Mol Hum Reprod 1997;3:101-7.

48. Minegishi T, Tano M, Igarashi M, Rokukawa S, Abe Y, Ibuki Y, Miyamoto K. Expression of folliclestimulating hormone receptor in human ovary. Eur J Clin Invest 1997;27:469-74.

49. Peluso JJ, Steger RW, Jaszczak S, Hafez ESE. Gonadotropin binding sites in human postmenopausal ovaries. Fertil Steril 1976;27:789-95. 
50. Nakano R, Shima K, Yamoto M, Kobayashi M, Nishimori K, Hiraoka J-I. Binding sites for gonadotropins in human postmenopausal ovaries. Obstet Gynecol 1989;73:196-200.

51. Vihko KK, Kujansuu E, Mörsky P, Huhtaniemi I, Punnonen R. Gonadotropins and gonadotropin receptors during the perimenopause. Eur J Endocrinol 1996;134:357-61. 


\title{
CHAPTER 2
}

\author{
SECTION I
}

\section{UTERO-OVARIAN VEIN BLOOD SAMPLING IN POSTMENOPAUSAL WOMEN}

\author{
Maas Jan Heineman', Alexander V. Sluijmer', \\ and Johannes L.H. Evers ${ }^{2}$
}

Department of Obstetrics and Gynaecology, De Wever Hospital, Heerlen'; Department of Obstetrics and Gynaecology, Academisch Ziekenhuis Maastricht and the University of Limburg, The Netherlands ${ }^{2}$ 


\section{Summary}

A technique for the collection of utero-ovarian vein blood in postmenopausal women is described. This technique enables the study of the endocrinology of postmenopausal ovaries and of the pelvic endocrine milieu. The sampling of blood from the utero-ovarian veins was almost always adequate, and there were no complications.

\section{Introduction}

Methods have been described for sampling ovarian venous blood during surgery in laboratory animals (1) and in the human female (2). In the human, sampling is particularly difficult outside the reproductive age range. Postmenopausal ovaries are small organs with a limited blood flow and a vulnerable vasculature. Literature on the technique of blood collection in this special group is not available. Various attempts were sought for circumventing the problems, and a suitable and practical method enabling blood sampling from the ovarian outflow tract in most postmenopausal women was found.

\section{Materials and methods}

The aim of the present study was to develop a suitable sampling method to study the relationship between function and morphology of the postmenopausal ovary. In women who underwent a unilateral or bilateral salpingo-oophorectomy with or without a hysterectomy, utero-ovarian blood sampling was performed. The purpose of the study was explained in detail to the participating patients, and informed consent was obtained. Approval of the Institutional Review Board was obtained.

In a pilot study, ovarian vein sampling using a needle inserted in the ovarian venous plexus was not successful. Suction via a syringe resulted in collapse of the vein and thus obstruction of blood flow. The rate of blood collection by means of constant suction was prohibitively low, and this technique interfered too much with the routine operative procedures. Thus it was necessary to find an easier method for the collection of blood from the utero-ovarian venous plexus. This was found in a simple blood-letting technique that makes it possible to sample blood from the pelvic area after selective clamping of the infundibulopelvic vessels.

Before the infundibulopelvic ligament is clamped, one must be certain that both tube and ovary are freed from surrounding structures. If necessary, adhesions are removed. The parietal peritoneum is gently opened, and the ovarian venous plexus, the ovarian artery, and the ureter are identified. The infundibulopelvic ligament is clamped selectively, and great care is taken to avoid the ureter. The ovarian venous plexus is bisected with a fine pair of scissors, and the flow of blood from the utero-ovarian efferent vessels is collected in a plastic cup (Fig. 1). This blood sample may be contaminated with a small 
mount of arterial blood from local arterioles. After the collection of approximately 30 $\mathrm{mL}$ of blood, the proximal side of the ovarian venous plexus is clamped. The remainder of the infundibulopelvic ligament can then be clamped, cut, and ligated. The procedure is repeated on the contralateral side to collect blood from the opposite ovary as well. After the sampling of blood, surgery can be completed as indicated.

To allow estimation of the selectivity of the procedure, androstenedione (A) levels were determined in the ovarian effluent thus obtained and compared with those in a peripheral blood sample drawn at the beginning of the operative procedure shortly before induction of anesthesia.

Both the central and peripheral blood samples were allowed to clot at room temperature, centrifuged, and the supernatant stored at $-20^{\circ} \mathrm{C}$ until assayed. The measurement of hormones was described previously (3).
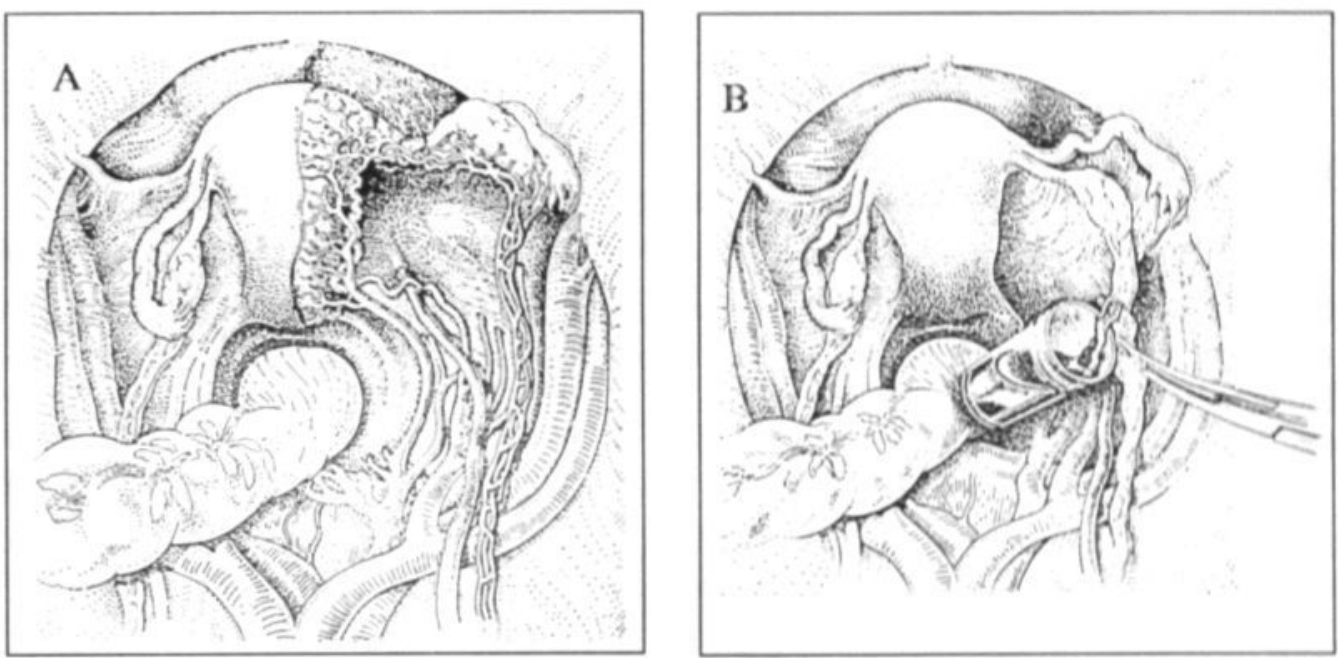

Fig. 1. (A), Utero-ovarian vasculature in the human female pelvis. (B), Utero-ovarian vein blood collection from the infundibulopelvic ligament in the human female.

Thirty-eight women agreed to participate in this study. All were at least 1 year postmenopausal, and all were scheduled for surgery for clinical indications. Clinical data on these patients are presented in Table 1. Statistical analysis was performed by the paired nonparametric Wilcoxon's sign rank test. 
Table 1. Clinical data of 38 postmenopausal patients undergoing a unilateral or bilateral salpingooophorectomy with or without a hysterectomy.

Age (y)

Time since menopause (y)

Indication for surgery

Endometrial carcinoma

Endometrial atypia

Endometrial hyperplasia

Leiomyoma uterus

CIN III

Benign ovarian cysts

Other indication
$63.8(53 \text { to } 81)^{\circ}$

13.7 (1 to 33 )

-Values are means with ranges in parentheses.

\section{Results}

The initial study group consisted of 38 postmenopausal women. Sampling of the utero-ovarian venous plexus was not successful in 2 women. In one of them, obesity was extreme and made it technically impossible to dissect the infundibulopelvic ligament; in the other patient, adhesions around the left infundibulopelvic ligament were too dense to sample this side appropriately.

In three patients, one ovary was missing because of previous gynecological procedures; the contralateral utero-ovarian venous plexus in these individuals was successfully sampled. Results of serum A measurements in these patients' blood samples, however, have not been included in the present study. Finally, in one patient the sampling procedure was successful, but results of serum A measurements were not included because of laboratory problems. Sampling of the utero-ovarian venous plexus occurred without complications; no perioperative hemorrhage occurred, and the postoperative recovery was uneventful.

Results of serum A measurements in peripheral blood samples and blood samples from the right and left utero-ovarian venous plexus are presented in Table 2 . In each individual patient, except one, the serum levels of $\mathrm{A}$ in the central compartment were elevated above the peripheral one. The mean A levels in the right and left utero-ovarian venous plexus were significantly higher than the mean A levels in the peripheral samples. The serum levels of $\mathrm{A}$ in the right utero-ovarian venous plexus did not differ from those in the left side. 
Table 2. Peripheral serum levels of $A$ in 32 postmenopausal patients compared with serum levels in blood from the left and right utero-ovarian venous plexuses.

\section{Serum A levels' \\ $\mathrm{ng} / \mathrm{dL}$}

$\begin{array}{llllll}\text { Peripheral vein } & 153 & \pm & 106 & (34 \text { to } 555) & {[117]^{2}} \\ \text { Left ovarian plexus } & 349 & \pm & 214 & (41 \text { to } 884) & {[282]} \\ \text { Right ovarian plexus } & 367 & \pm & 215 & (68 \text { to } 1,103) & {[327]}\end{array}$

${ }^{\prime}$ Conversion factor to SI unit, 0.0349.

${ }^{2}$ Wilcoxon, $P<0.0001$; the peripheral vein mean value was significantly different from the mean for the left and right ovarian plexus. Values are means $\pm S D$ with ranges in parentheses and medians in brackets.

\section{Discussion}

This study is part of an investigation into the relationship between morphological characteristics of postmenopausal ovaries and their endocrine function. The endocrine function of the ovaries is best evaluated by direct blood sampling at the time of oophorectomy and a technique of utero-ovarian blood sampling had thus to be developed.

From the literature it was known that ovarian vein sampling could be helpful in confirming the location of hormone-producing ovarian tumors (4). Percutaneous transfemoral venous blood sampling of the ovaries by way of catheterization has been described, and appropriate imaging techniques have been developed for monitoring the procedure (2). Direct utero-ovarian blood collection in the baboon per laparoscope has been described (1). It is doubtful, however, whether this laparoscopic technique is applicable in the human. The small dimensions of the postmenopausal vessels in women and the inherent risks of the procedure render it too perilous after the menopause.

In spite of many reports in the literature on intra-operative ovarian vein blood collection in women with virilizing tumors, an accurate description of the techniques used is lacking. We only succeeded in tracing one study in which the authors gave a brief description of their way of sampling the ovarian veins (5). These authors wrote that the ovarian vein sample was obtained by either aspirating the blood with a needle and syringe or by dividing the vessel and collecting the blood in a small sterile glass tube. They did not mention problems or complications associated with their way of sampling. From their results, however, it became obvious that they could obtain only a small amount of blood.

In our experience, insertion of a needle in the ovarian vein and suction by syringe are likely to cause the vein to collapse. Only a limited volume of blood can be obtained in this way, and the technique is very time-consuming, which interferes with the routine operative procedures. 
The technique here presented allows for a sufficiently large volume of blood to be obtained from the utero-ovarian venous plexus within a few minutes. The technique was adequate in 36 of 38 patients, and no complications were encountered.

The results of the A measurements show a significant elevation in the central samples. Because A is a product of hormone synthesis in postmenopausal ovaries, these results confirm the validity of the sampling method.

\section{Acknowledgements}

The authors thank their colleagues from the Department of Obstetrics and Gynaecology, De Wever Hospital, Heerlen, The Netherlands, for technical assistance. We also thank Frank de Jong, M. Sc., Department of Endocrinology and Reproduction, Erasmus University, Rotterdam, The Netherlands, for performing endocrine assays. Inge van Noortwijk was responsible for the artwork of Figure 1.

\section{References}

1. Shaikh AA, Shaikh SA, Celaya CL. Utero-ovarian vein blood collection by the use of a laparoscope in the baboon. Biol Reprod 1981;24:455-9.

2. Sörensen R, Moltz L, Schwartz U. Technical difficulties of selective venous blood sampling in the differential diagnosis of female hyperandrogenism. Cardiovasc Intervent Radiol 1986;9:7582 .

3. Kwekkeboom DJ, De Jong FH, Van Hemert AM, Vandenbroucke JP, Valkenburg HA, Lamberts SWJ. Serum gonadotropins and $\alpha$-subunit decline in aging normal postmenopausal women. J Clin Endocrinol Metab 1990;70:944-50.

4. DeFreitas EA, Dudzinski MR, LaRocque JC, Coddington CC. Ovarian vein sampling in rapidly progressing virilization. A case report. J Reprod Med 1991;36:546-8.

5. Judd HL, Judd GE, Lucas WE, Yen SSC. Endocrine function of the postmenopausal ovary: concentration of androgens and estrogens in ovarian and peripheral vein blood. J Clin Endocrinol Metab 1974;39:1020-4. 


\title{
CHAPTER 2
}

\author{
SECTION II
}

\section{PERIPHERAL VEIN, OVARIAN VEIN AND OVARIAN TISSUE LEVELS OF INHIBIN IN A POSTMENOPAUSAL PATIENT WITH A GRANULOSA CELL TUMOUR}

\author{
Alexander V. Sluijmer', Maas J. Heineman', \\ Johannes L.H. Evers ${ }^{2}$, and Frank H. de Jong ${ }^{3}$
}

Department of Obstetrics and Gynaecology, De Wever Hospital, Heerlen'; Department of Obstetrics and Gynaecology, Maastricht State University Hospital, Maastricht ${ }^{2}$; Department of Endocrinology and Reproduction, Erasmus University, Rotterdam, The Netherlands ${ }^{3}$ 


\section{Summary}

In a patient with a granulosa cell tumour, stage 1a1, peripheral and ovarian vein blood samples were drawn before, during and after bilateral oophorectomy. Before operation inhibin and follicle-stimulating hormone levels were in the premenopausal range, whereas the peripheral level of oestradiol and luteinizing hormone were in the normal postmenopausal range. In the ovarian vein at the side of the tumour, inhibin and oestradiol levels were elevated, whereas in the contralateral ovarian vein the concentrations of inhibin and oestradiol were in the same range as in the peripheral vein. Immunoreactive inhibin levels in the homogenized tumour were 23 times higher than in the contralateral ovary, whereas inhibin bioactivities in the same samples amounted to 126 and $14 \mathrm{U} / \mathrm{mg}$ protein, respectively. After removal of the tumour, peripheral serum follicle-stimulating hormone and inhibin levels were in the normal postmenopausal range again. We conclude that inhibin can have a role as a marker for granulosa cell tumours.

\section{Introduction}

Granulosa cell tumours are hormone-producing ovarian stromal tumours. They account for approximately $3 \%$ of ovarian neoplasms and for as much as $8 \%$ of ovarian malignancies (1-3).

The diagnosis of granulosa cell tumour is usually made after laparotomy. Endocrinological studies with pre- and postoperative data are not available.

The predominance of early stage tumours ( $90 \%$ stage 1 lesions) indicates the low malignancy of granulosa cell tumours compared with most ovarian carcinomas. However, Fox et al. (4) stated that nearly $50 \%$ of women with granulosa cell tumours will die from tumour-related events within 20 years from the moment of diagnosis. This is likely to be caused by the high recurrence rate of more than $30 \%$ in the group with stage 3 and 4 carcinomas and a mortality rate of $80 \%$ within 5 years in this group. Women with stage lal granulosa cell carcinoma incur only a $8.9 \%$ risk of developing a recurrence (2).

The sooner the granulosa cell tumour is detected, the better the prognosis will be. The presence of a marker for granulosa cell tumours can improve the prognosis, especially of recurrent disease. Oestradiol is a well-known circulating marker for granulosa cell tumours, but in one-third of cases the granulosa cell tumours are inactive as far as steroid production is concerned and in patients with small granulosa cell tumours the oestradiol levels in peripheral blood are rarely elevated $(1,5)$.

A recent report suggested the possibility of inhibin as a marker for granulosa cell tumours (5): recurrences of granulosa cell tumours were related retrospectively to changes in peripheral serum inhibin levels.

In the present case report a patient is presented with a granulosa cell tumour in whom we were able to obtain peripheral blood samples before, during and after oophorectomy. In addition, bilateral ovarian vein blood sampling was performed during surgery. 


\section{Case history}

A 48-year-old woman visited our Department because of painless vaginal bloodloss. She had been postmenopausal for 18 months. At pelvic examination, the right ovary was found to be slightly enlarged. A curettage was performed together with a laparoscopy. During laparoscopy the right ovary appeared abnormal and enlarged with a diameter of $4 \mathrm{~cm}$. However, no laparotomy was performed because the patient had requested to be informed about the laparoscopy findings first. Histological examination of the tissue obtained at the curettage revealed endometrium without mitotic figures, comparable to that observed during the early proliferative phase of the cycle.

Because of her participation in a project on gonadotrophin regulation in postmenopausal women, the patient received an intramuscular injection of $3.75 \mathrm{mg}$ triptorelin (a gonadotrophin-releasing hormone agonist) 14 days prior to laparotomy. A peripheral venous blood sample was taken before the administration of triptorelin. One day before oophorectomy and a few minutes before the start of the operation, repeated peripheral venous blood samples were obtained. During surgery the right ovarian mass was confirmed and a small amount of peritoneal fluid was observed and collected. Blood was sampled from both ovarian veins. A right salpingo-oophorectomy was performed. Direct histological examination revealed a granulosa cell tumour. Therefore, total hysterectomy with salpingo-oophorectomy of the remaining left side and omentectomy were performed. Histological examination revealed that the well-differentiated granulosa cell tumour was located in the right ovary only and confined within it. No tumour cells were found in the peritoneal fluid. Consequently, the tumour was diagnosed as a stage lal tumour. The endometrium again showed signs of slight proliferation.

Six weeks after surgery, the patient visited the out-patient Department. She now complained of hot flushes. Peripheral blood sampling was repeated.

\section{Methods}

Serum hormone concentrations were measured in duplicate. All between-assay coefficients of variation were below $8 \%$.

Serum $\mathrm{LH}$ and $\mathrm{FSH}$ were determined by luminescence assay with the Amerlite LH-30 and FSH-60 kits (Amersham International, Amersham, UK). The results are expressed in terms of International Reference Preparations: 68/40 for LH and 78/549 for FSH. The detection limits were $0.12 \mathrm{U} / \mathrm{L}$ for $\mathrm{LH}$ and $0.5 \mathrm{U} / \mathrm{L}$ for FSH.

Serum oestradiol and testosterone were measured by radio-immunoassay (Coata-Count, Diagnostic Products, Los Angeles, CA). The detection limits were $0.03 \mathrm{nmol} /$ $\mathrm{L}$ for oestradiol and $0.2 \mathrm{nmol} / \mathrm{L}$ for testosterone.

Serum oestrone was measured after ether extraction by radioimmunoassay (Biolab, Belgium). The detection limit for oestrone was $0.09 \mathrm{nmol} / \mathrm{L}$.

Serum inhibin levels were estimated by radioimmunoassay, using an antiserum against purified $32-\mathrm{kD}$ bovine inhibin (No. 1989) and iodinated $32-\mathrm{kD}$ bovine inhibin 
as tracer (6). These materials were obtained from Dr G Bialy, NIH Contraceptive Development Branch Rockville, MD, USA. The standard used was a bovine follicular fluid preparation with an arbitrary potency of $1 \mathrm{U}$ of inhibin per $\mu \mathrm{g}$ protein. The International Research Standard for inhibin (86/690) has a relative specific activity of $60 \pm 10$ $\mathrm{U} / \mu \mathrm{g}$ (mean $\pm \mathrm{SEM}, \mathrm{n}=5$ ) when expressed in terms of this bovine follicular fluid standard (7). In the samples of the standard curve, pooled serum from postmenopausal women was added; these sera were selected on the basis of undetectable inhibin levels in previous assays. Inhibin concentrations in serum samples from 53 postmenopausal women amounted to $0.67 \pm 0.33 \mathrm{kU} / \mathrm{L}$ (mean $\pm \mathrm{SD}$; range $0-1.13 \mathrm{kU} / \mathrm{L}$ ) when measured using these materials, whereas levels in 8 premenopausal women varied between $2.6 \pm 0.30$ (week 1 of the menstrual cycle) and $5.1 \pm 0.55$ (week 3 of the menstrual cycle) kU/L.

Parts of the tumour and left ovary were homogenized as described earlier for Sertoli cell tumours (7). Immunoreactivity of inhibin was measured in these homogenates, as well as inhibin bioactivity, using the suppression of FSH secretion from cultured rat pituitary cells (7) as a response parameter.

\section{Results}

Peripheral and ovarian vein hormone levels are listed in Table 1.

Table l. Hormone levels in peripheral (P) and ovarian (O) venous seruma.

\begin{tabular}{|c|c|c|c|c|c|c|c|}
\hline & & $\begin{array}{l}\text { Inhibin } \\
(\mathrm{kU} / \mathrm{L})\end{array}$ & $\begin{array}{c}\mathrm{LH} \\
(\mathrm{U} / \mathrm{L})\end{array}$ & $\begin{array}{c}\text { FSH } \\
(\mathrm{U} / \mathrm{L})\end{array}$ & $\frac{\mathrm{E}_{1}}{(\mathrm{nmol} / \mathrm{L})}$ & $\underset{(\mathrm{nmol} / \mathrm{L})}{\mathrm{E}_{2}}$ & $\begin{array}{c}\text { Testosterone } \\
(\mathrm{nmol} / \mathrm{L})\end{array}$ \\
\hline Day - 14 & $: \mathbf{P}$ & 3.6 & 23.3 & 5.9 & 0.63 & 0.07 & 0.4 \\
\hline Day -1 & $: \mathbf{P}$ & 2.4 & 9.3 & 4.9 & 0.59 & 0.03 & 0.1 \\
\hline \multirow[t]{3}{*}{ Day 0} & $: \mathbf{P}$ & 2.9 & 10.6 & 5.1 & 0.59 & 0.04 & 0.3 \\
\hline & L-O & 2.7 & 11.5 & 4.7 & 0.74 & 0.03 & 1.5 \\
\hline & R-O & 5.3 & 9.5 & 4.4 & 0.70 & 0.58 & 0.5 \\
\hline Day +42 & $: \mathbf{P}$ & 0.3 & 45.0 & $>117.0$ & 0.59 & $<0.03$ & 0.3 \\
\hline Months +4 & $: \mathbf{P}$ & 0.4 & & & & & \\
\hline Months +8 & $: \mathbf{P}$ & 0.5 & & & & & \\
\hline
\end{tabular}

Before the administration of triptorelin, the peripheral concentration of $\mathrm{LH}$ was in the postmenopausal range. Surprisingly, the levels of FSH and inhibin were premenopausal. Oestradiol, oestrone and testosterone were in the postmenopausal range. The day before surgery, the LH level was found to be decreased as a result of the admini- 
stration of triptorelin. On the other hand, the FSH level did not change and neither did oestradiol, oestrone or testosterone. No influence of triptorelin was observed on the peripheral level of inhibin. The peripheral hormone levels during operation were not different from those taken prior to surgery. No substantial differences were found between the peripheral hormone levels and the levels in the left ovarian vein. However, in the right ovarian vein the levels of inhibin and oestradiol appeared to be higher than the levels found in the left ovarian vein. No left-to-right differences were observed for the other hormones.

Levels of immunoreactive inhibin in the homogenates of the tumour and left ovary were 59.6 and $<0.7 \mathrm{U} / \mathrm{mg}$ protein, respectively, whereas inhibin bioactivities in the same samples amounted to 126 and $14 \mathrm{U} / \mathrm{mg}$ protein, respectively.

Six weeks postoperatively, all hormone levels were in the normal postmenopausal range. At 4 and 8 months after surgery the inhibin serum levels were still in the normal postmenopausal range and no clinical signs of recurrences were noted.

\section{Discussion}

Inhibin is a glycoprotein, consisting of a heterodimer of two subunits, $\alpha$ and $\beta$, linked by disulphide bonds. The hormone surpresses the pituitary secretion of FSH preferentially.

Inhibin is detectable in the circulation throughout the menstrual cycle in normal women and is produced by the granulosa cells in the ovary, which explains the observed rise in the late follicular phase in parallel with oestradiol (8). This is consistent with the concept that both hormones are products of the maturing follicle. However, there is doubt about the hypothesis that the selective suppression of FSH during the follicular phase is due to inhibin from the dominant follicle, because Illingworth et al. (9) found no differences between inhibin levels in the ovarian veins draining the dominant ovary and the contralateral ovarian veins during the late follicular phase.

In the luteal phase, the levels of immunoreactive inhibin continue to rise in parallel with progesterone $(10,11)$. This suggests that inhibin is also a secretory product of the corpus luteum, as was confirmed by the finding of higher ovarian vein levels of inhibin at the side of the corpus luteum compared to those at the contralateral side (9), and of immunoreactive and bioactive inhibin subunits in human corpora lutea $(12,13)$.

Our patient entered a research program for which a number of blood samples had to be taken. Because of this fortuitous circumstance, we were able to perform endocrine measurements before and after the extirpation of the granulosa cell tumour.

The level of oestradiol in the right ovarian vein at the side of the tumour was clearly elevated. In the left ovarian vein, the oestradiol level did not differ from the peripheral blood level. Consequently, the increased oestradiol level in the right ovarian vein was the result of the production of oestradiol by the tumour. However, the production was apparently too low to increase the peripheral level of oestradiol above the normal 
postmenopausal level. This confirms previous reports that oestradiol is not an optimal tumour marker for granulosa cell tumours, especially not in small tumours (5).

Although the peripheral oestrogen concentrations were in the normal postmenopausal range, the endometrium showed minimal signs of proliferation. No mitotic figures were seen and the endometrium was comparable with endometrium found in the early proliferative phase. As the serum oestradiol level of the right ovarian vein was in the range of the early proliferative phase of the menstrual cycle, a local and circumscript effect of oestradiol on endometrium cannot be excluded.

No differences between peripheral and ovarian vein concentrations were seen for $\mathrm{LH}$, oestrone or testosterone. The low peripheral FSH level, in contrast to postmenopausal LH and oestradiol levels, suggests the presence of increased inhibin production. The increased level of inhibin found in the ovarian vein at the side of the tumour, as well as the high levels of immunoreactive and bioactive inhibin in the tumour tissue indicate the granulosa cell tumour as the source of inhibin. The relatively high ratio of bio- over immunoreactivity of inhibin in the tumour tissue suggests the presence of follistatin, which is also produced by granulosa cells (14).

The markedly increased peripheral levels of inhibin show also that small granulosa cell tumours are able to produce detectable amounts of inhibin. Lappöhn et al., in a retrospective analysis of serial measurements of serum inhibin, demonstrated that a rise of inhibin following extirpation of a granulosa cell tumour predicted recurrence of the tumour months before the onset of clinical signs and symptoms (5).

Recently, Matzuk et al. (15) showed that targeted deletion of the inhibin $\alpha$-gene in mice causes granulosa cell tumours in the homozygous offspring. These authors suggested that inhibin can act as a gonad-specific tumour suppressor, and also indicated that gonadal tumours might suffer from a relative decrease of expression of inhibin $\alpha$ subunit. In contrast, our data show that a granulosa cell tumour contains relatively high levels of bioactive inhibin, as is indicated also by the suppressed FSH levels in the patient. This observation, together with the finding of high levels of bioactive inhibin in dog Sertoli cell tumours (7), makes the hypothesis of tumour suppression by $\alpha$-inhibin less likely.

We conclude that inhibin is a potential early marker for granulosa cell tumours. This possibility remains to be tested by a study of an unselected series of patients. The specific site of production of inhibin in our patient, i.e. the granulosa cell tumour, was demonstrated; furthermore, detectable changes in peripheral serum inhibin levels were present in the absence of an oestradiol increase in this postmenopausal patient with a small granulosa cell tumour. It is likely that the FSH levels in our patient were decreased because of the presence of inhibin. This confirms a role for inhibin in the modulation of FSH secretion. 


\section{Acknowledgements}

We want to thank Joh. Koudstaal and P. Theunissen for evaluating the histological specimens and $\mathrm{A}$. Gijzen and $\mathrm{H}$. Janssen for performing endocrine assays.

\section{References}

1. McCormack TP, Riddick DH. Hormonal function of a granulosa cell tumor. Obstet Gynecol $1976 ; 48: 18 s-21 s$.

2. Evans III AT, Gaffey TA, Malkasian GD, Annegers JF. Clinico-pathologic review of 118 granulosa and 82 theca cell tumors. Obstet Gynecol 1980;55:231-8.

3. Ohel G, Kaneti H, Schenker JG. Granulosa cell tumors in Israel: a study of 172 cases. Gynecol Oncol 1983;15:278- 86.

4. Fox H, Agrawal K, Langley FA. A clinicopathologic study of 92 cases of granulosa cell tumor of the ovary with special reference to the factors influencing prognosis. Cancer 1975:35:231-41.

5. Lappöhn RE, Burger HG, Bouma J, Bangah M, Krans M, de Bruijn HWA. Inhibin as a marker for granulosa-cell tumors. N Engl J Med 1989;321:790-3.

6. Robertson DM, Hayward S, Irby D, Jacobsen J, Clarke L, McLachlan RI, de Kretser DM. Radioimmunoassay of rat serum inhibin: changes after PMSG stimulation and gonadectomy. Mol Cell Endocrinol 1988;58:1-8.

7. Grootenhuis AJ, van Sluijs FJ, Klaij IA, Steenbergen J, Timmerman MA, Bevers MM, Dieleman SJ, de Jong FH. Inhibin, gonadotrophins and sex steroids in dogs with Sertoli cell tumours. J Endocrinol 1990;127:235-42.

8. Ying SY. Inhibins, activins, and follistatins: gonadal proteins modulating the secretion of folliclestimulating hormone. Endocr Rev 1988;9:267-93.

9. Illingworth PJ, Reddi K, Smith KB, Baird DT. The source of inhibin secretion during the human menstrual cycle. J Clin Endocrinol Metab 1991;73:667-73.

10. McLachlan RI, Robertson DM, Healy DL, Burger HG, de Kretser DM. Circulating immunoreactive inhibin levels during the normal human menstrual cycle. J Clin Endocrinol Metab 1987;65:954-61.

11. De Kretser DM, Robertson DM. The isolation and physiology of inhibin and related proteins. Biol Reprod 1989;40:33-47.

12. Smith KB, Millar MR, McNeilly AS, Illingworth PJ, Fraser HM, Baird DT. Immunocytochemical localization of inhibin $\alpha$-subunit in the human corpus luteum. J Endocrinol 1991; 129:155-60.

13. Yamoto M, Minami S, Nakano R. Immunohistochemical localization of inhibin subunits in human corpora lutea during menstrual cycle and pregnancy. J Clin Endocrinol Metab 1991;73:470-7. 
14. Shimasaki S, Koga M, Buscaglia ML, Simmons DM, Bicsak TA, Ling N. Follistatin gene expression in the ovary and extragonadal tissues. Mol Endocrinol 1989;3:651-9.

15. Matzuk MM, Finegold MJ, Su J-GJ, Hsueh AJW, Bradley A. $\alpha$-Inhibin is a tumour-suppressor gene with gonadal specificity in mice. Nature 1992;360:313-9. 


\section{CHAPTER 3}

\section{PITUITARY DOWN-REGULATION WITH A SINGLE DEPOT-DOSE OF A GnRH AGONIST (TRIPTORELIN) IN POSTMENOPAUSAL WOMEN}

Alexander V. Sluijmer', Maas Jan Heineman'2,
Renato de Leeuw ${ }^{3}$, and Johannes L.H. Evers'

Department of Obstetrics and Gynaecology, Academisch Ziekenhuis Maastricht' ${ }^{1}$; Department of Obstetrics and Gynaecology, De Wever Ziekenhuis, Heerlen²;

Scientific Development Group, Organon International B.V., Oss, The Netherlands ${ }^{3}$ 


\section{Abstract}

Gonadotropin levels were determined in 17 postmenopausal women before and after administering a single depot-dose of the GnRH agonist triptorelin. E2 levels of all samples were in the normal (low) postmenopausal range and no differences were found when the patients were grouped according to chronological age, or time after menopause. Pre-GnRH agonist levels of LH and FSH were in the normal (high) postmenopausal range. Two weeks after medication, $\mathrm{LH}$ and FSH had decreased to premenopausal levels $(\mathrm{P}<0.0001)$. Eight weeks after medication, $\mathrm{LH}$ levels were still low whereas FSH levels had risen significantly again $(\mathrm{P}<0.0001)$. Both $\mathrm{LH}$ and FSH levels, however, were still significantly below the serum concentrations before the administration of triptorelin $(\mathrm{P}<0.0001)$. The pre-GnRH agonist level of $\mathrm{FSH}$ was significantly higher in women $>67$ years old $(\mathrm{P}<0.05)$, as compared to women $\leq 67$ years. Two weeks after medication both $\mathrm{LH}$ and FSH levels were significantly higher in women more than 15 years after menopause $(\mathrm{P}<0.05)$, as compared to those $\leq 15$ years. The same was found for FSH in women $>67$ years old. No further significant differences were noted. This study demonstrates a significant decrease of LH and FSH serum levels in postmenopausal women within two weeks after administration of a single depot-dose of the $\mathrm{GnRH}$ agonist triptorelin. After eight weeks, in contrast to premenopausal women, both $\mathrm{LH}$ and FSH, although rising, were still significantly suppressed.

\section{Introduction}

Continuous or frequent intermittent administration of a $\mathrm{GnRH}$ agonist (GnRHa) results in pituitary down-regulation. In a recent study (1), the effects have been studied of a single depot-dose of the GnRHa triptorelin on serum levels of LH and FSH in the early follicular and midluteal phases of the menstrual cycle.

In postmenopausal women, no studies concerning the gonadotropin changes following the administration of a single depot-dose of a $\mathrm{GnRHa}$ have been published so far.

As part of a more extensive investigation into the relationship between morphological characteristics of postmenopausal ovaries and their endocrine function, the GnRHa triptorelin was administered. In the present study we report the effect of a single depotdose of the GnRHa triptorelin on pituitary and ovarian function in a group of 17 postmenopausal women.

\section{Patients and methods}

The effect of a GnRHa was studied in 17 postmenopausal women. Their age ranged from 54-81 years (mean 66.9 years). Women were considered postmenopausal if their last menstrual period was at least twelve months before the onset of the study. The 
range of the postmenopausal period was 1-29 years (mean 15.9 years). None of the patients had had estrogen replacement therapy for at least six months preceeding the investigation. The protocol used for this study was approved by the hospital ethics committee. All patients signed an informed consent.

The active substance in Decapeptyl is triptorelin (D-Trp 6 -LHRH) a synthetic agonistic analogue of the naturally occurring GnRH. Decapeptyl-CR (Ferring B.V., Haarlem, The Netherlands) contains $3.75 \mathrm{mg}$ of triptorelin, dispersed in biodegradable micro-capsules. The depot preparation is designed to release the agonist at an average rate of $100 \mu \mathrm{g} /$ day over a 30-day period (2).

Before the administration of the $\mathrm{GnRHa}$, blood was drawn from an antecubital vein. Further blood samples were obtained 2 and 8 weeks after the depot injection. All blood samples were centrifuged at $3000 \mathrm{rev} / \mathrm{min}$ for $10 \mathrm{~min}$ and the serum was stored at $-20^{\circ} \mathrm{C}$ until assayed.

Table 1. Range and median E2 serum levels ( $\mathrm{pmol} / \mathrm{L}$ ) in 17 postmenopausal women before (E2 I). 2 (E2 2), and 8 (E2 3) weeks after the administration of a single depot-dose of the GnRHa triptorelin. The effect of age and time after last menstrual period (LMP) on the serum level of E2 is also shown.

\section{E2 1}

E2 2

E2 3

17 menopausal women

$\begin{array}{llll}\text { Range } & 7-113 & 5-143 & 20-118 \\ \text { Median } & 60.0 & 50.0 & 53.0\end{array}$

Age $\leq 67$ years $(n=9)$

$\begin{array}{llll}\text { Range } & 7-113 & 5-143 & 20-118 \\ \text { Median } & 66.1 & 60.0 & 61.0\end{array}$

Age $>67$ years $(n=8)$

$\begin{array}{llll}\text { Range } & 21-91 & 22-78 & 31-69 \\ \text { Median } & 54.5 & 49.0 & 50.5\end{array}$

LMP $\leq 15$ years $(\mathrm{n}=9)$

$\begin{array}{llll}\text { Range } & 7-113 & 5-143 & 20-118 \\ \text { Median } & 66.0 & 45.0 & 61.0\end{array}$

LMP > 15 years $(\mathrm{n}=8)$

$\begin{array}{llll}\text { Range } & 21-91 & 22-78 & 31-69 \\ \text { Median } & 57.0 & 53.0 & 50.0\end{array}$

Sign rank test (Wilcoxon): within rows, no significant differences in medians were found.

Mann-Whitney U-test: within columns for age and LMP, no significant differences in medians were found. 
In all serum samples, $\mathrm{LH}$ and FSH were assayed in duplicates using commercially available immunofluorometric assays (Delfia ${ }^{R}$, Pharmacia, Woerden, The Netherlands) with IS $80 / 552$ and IRP $78 / 549$ as the respective standards. The detection limit of the Delfia hFSH and hLH assays is $0.05 \mathrm{U} / \mathrm{L}$, if the limit of sensitivity is defined as two standard deviations above the mean of ' 0 ' standard measurement values (mean value+ 2 S.D.). The intra- and interassay coefficients of variation were less than $7.5 \%$ for $\mathrm{LH}$ and less than $5 \%$ for FSH. All samples from an individual woman were analyzed in the same assay to eliminate interassay variation.

E2 levels were measured using a RIA kit (Diagnostic Products Corp., Los Angeles, CA). The intra- and interassay coefficients of variation were less than $15 \%$ and less than $19 \%$, respectively.

Table 2. Range and median LH serum levels (U/L) in 17 postmenopausal women before (LHI), 2 (LH2), and 8 ( LH3) weeks after the administration of a single depot-dose of the GnRHa triptorelin. The effect of age and time after last menstrual period (LMP) on the LH serum level is also shown.

LH1 LH2 LH3

17 menopausal women

$\begin{array}{llll}\text { Range } & 11.0-40.8 & 2.8-11.8 & 0.05-20.1 \\ \text { Median } & 26.8^{1,2} & 5.7^{1} & 6.1^{2}\end{array}$

Age $\leq 67$ years $(n=9)$

$\begin{array}{llll}\text { Range } & 11.0-40.8 & 2.8-6.9 & 0.1-20.1 \\ \text { Median } & 26.5^{1,2} & 5.0^{1} & 7.2^{2}\end{array}$

Age $>67$ years $(n=8)$

$\begin{array}{llll}\text { Range } & 17.5-38.1 & 4.5-11.8 & 0.05-19.3 \\ \text { Median } & 29.9^{1,2} & 6.7^{1} & 4.3^{2}\end{array}$

LMP $\leq 15$ years $(\mathrm{n}=9)$

$\begin{array}{llll}\text { Range } & 11.0-40.8 & 2.8-6.4 & 0.1-16.9 \\ \text { Median } & 20.3^{1,2} & 5.0^{1, \mathrm{a}} & 3.9^{2}\end{array}$

LMP $>15$ years $(n=8)$

$\begin{array}{llll}\text { Range } & 17.5-38.1 & 4.5-11.8 & 0.05-20.1 \\ \text { Median } & 29.9^{1,2} & 6.9^{1, .} & 11.4^{2}\end{array}$

Sign rank test (Wilcoxon), $P<0.05$ : within rows, medians with identical number superscripts are significantly different.

Mann-Whitney $U$-test, $P<0.05$; within columns for age and LMP, medians with identical character superscripts are significantly different. 
In order to investigate the effect of chronological age on the LH and FSH serum levels, the 17 postmenopausal women were subdivided into two groups of $\leq 67$ years $(n=9)$ and $>67$ years $(n=8)$, respectively, using the median as dividing point. Also, the influence of time after menopause on serum levels of LH and FSH was investigated by dividing the postmenopausal patients into two groups of $\leq 15$ years after the menopause $(n=9)$ and $>15$ years after the menopause $(n=8)$, with the median as dividing point.

Wilcoxon's signed rank test was used for the statistical analysis of differences in LH and FSH serum levels between individual blood samples of all 17 postmenopausal women. The influence of chronological age and time after menopause on LH and FSH serum levels was studied by applying the Mann-Whitney U-test.

Table 3. Range and median FSH serum levels (U/L) in 17 pastmenopausal women before (FSHI), 2(FSH2), and 8 (FSH3) weeks after the administration of a single depot-dose of the GnRHa triptorelin. The effect of age and time after last menstrual period (LMP) on the FSH serum level is also shown.

FSH1

FSH2

FSH3

17 menopausal women

$\begin{array}{llll}\text { Range } & 26.5-91.9 & 2.6-12.5 & 5.3-74.4 \\ \text { Median } & 56.3^{1,2} & 7.4^{1,3} & 21.6^{2,3}\end{array}$

Age $\leq 67$ years $(n=9)$

$\begin{array}{lll}\text { Range } & 26.5-91.6 & 2.6-10.9 \\ \text { Median } & 46.2^{1,2,9} & 4.3^{1,3,4}\end{array}$

Age $>67$ years $(\mathrm{n}=8)$
Range
53.1-91.9
7.1-12.5
6.7-74.4
Median
$70.8^{1,2, a}$
9.4,3.9.
$21.3^{2.3}$

LMP $\leq 15$ years $(\mathrm{n}=9)$

Range

26.5-91.6

2.8-10.9

5.3-72.9

Median

$46.6^{1.2}$

$4.7^{1,3,6}$

$21.6^{2,3}$

LMP > 15 years $(\mathrm{n}=8)$

Range

32.5-91.9

2.6-12.5

6.7-74.4

Median

$70.8^{1.2}$

$9.4^{1,3,6}$

$23.9^{2.3}$

Sign rank test (Wilcoxon), $P<0.05$ : within rows, medians with identical number superscripts are significantly different.

Mann-Whitney U-test, $P<0.05$ : within columns for age and LMP, medians with identical character superscripts are significantly different. 


\section{Results}

During and after the administration of the GnRHa, no side effect of the drug was noted. The E2 serum levels before medication were in the normal postmenopausal range. Two and eight weeks after the administration of the GnRHa, no differences in E2 serum levels were noted (Table 1). The serum levels of LH and FSH before and after treatment are shown in Table 2 and 3 and Figures 1 and 2. The pre-GnRHa LH and FSH serum levels were in the normal postmenopausal range. Two weeks after the administration of the GnRHa, the LH and FSH serum levels were significantly suppressed $(\mathrm{P}<0.0001)$. Eight weeks after the administration of the GnRHa, only the FSH serum level had increased significantly again $(\mathrm{P}<0.0001)$. Both LH and FSH serum levels, however, were still below the pre-GnRHa levels $(\mathrm{P}<0.0001)$. When evaluating the effect of chronological age on the LH and FSH serum levels, no statistical differences were found between the E2 serum levels of these two groups for all samples (Table 1). Serum levels of LH and FSH before and after the administration of the GnRHa in these groups are shown in Table 2 and 3. The pre-GnRHa levels of LH were not significantly different between both groups. The pre-GnRHa levels of FSH in the older group, however, were significantly higher $(\mathrm{P}<0.05)$. Two weeks after the administration of the $\mathrm{GnRHa}$, the $\mathrm{LH}$ serum level was the same in both groups. FSH, however, was significantly higher in the group of olderpostmenopausal women $(\mathrm{P}<0.05)$. LH and FSH serum levels eight weeks after the administration of the GnRHa were the same in both groups.

\section{$\mathrm{LH}(\mathrm{U} / \mathrm{L})$}

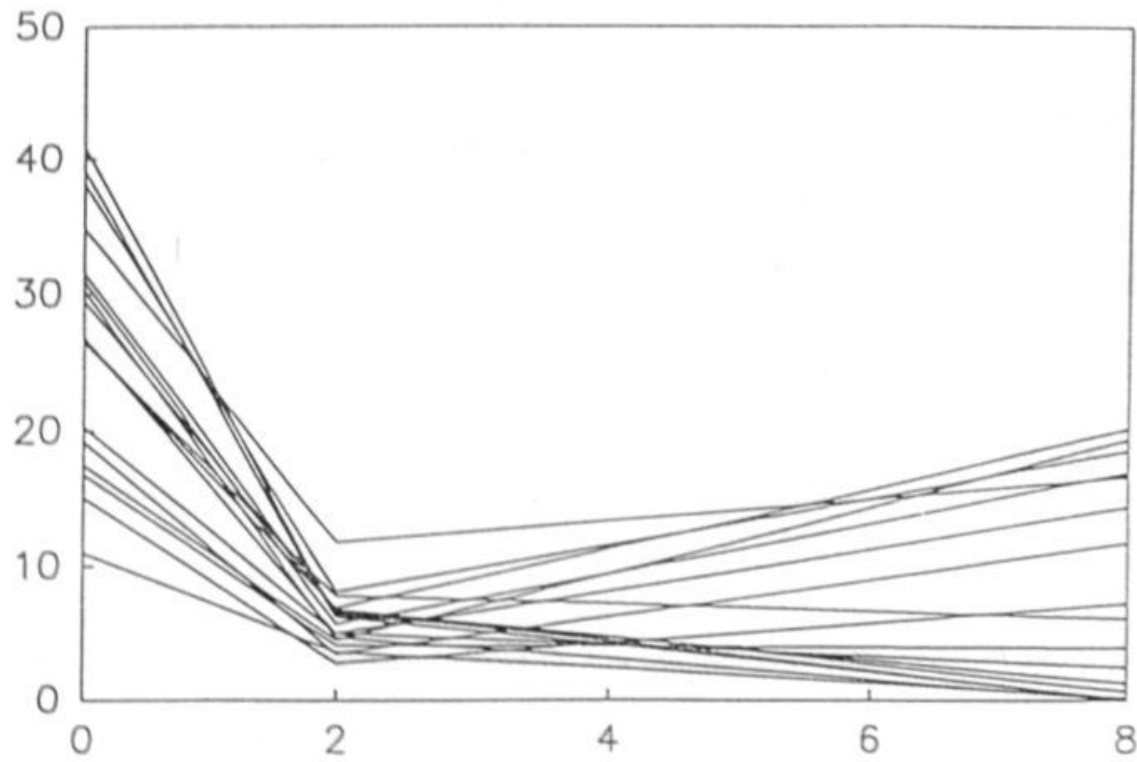

Fig. 1. LH serum levels (U/L) in 17 postmenopausal women before, 2 and 8 weeks after the administration of a single depot-dose of the GnRHa triptorelin. 


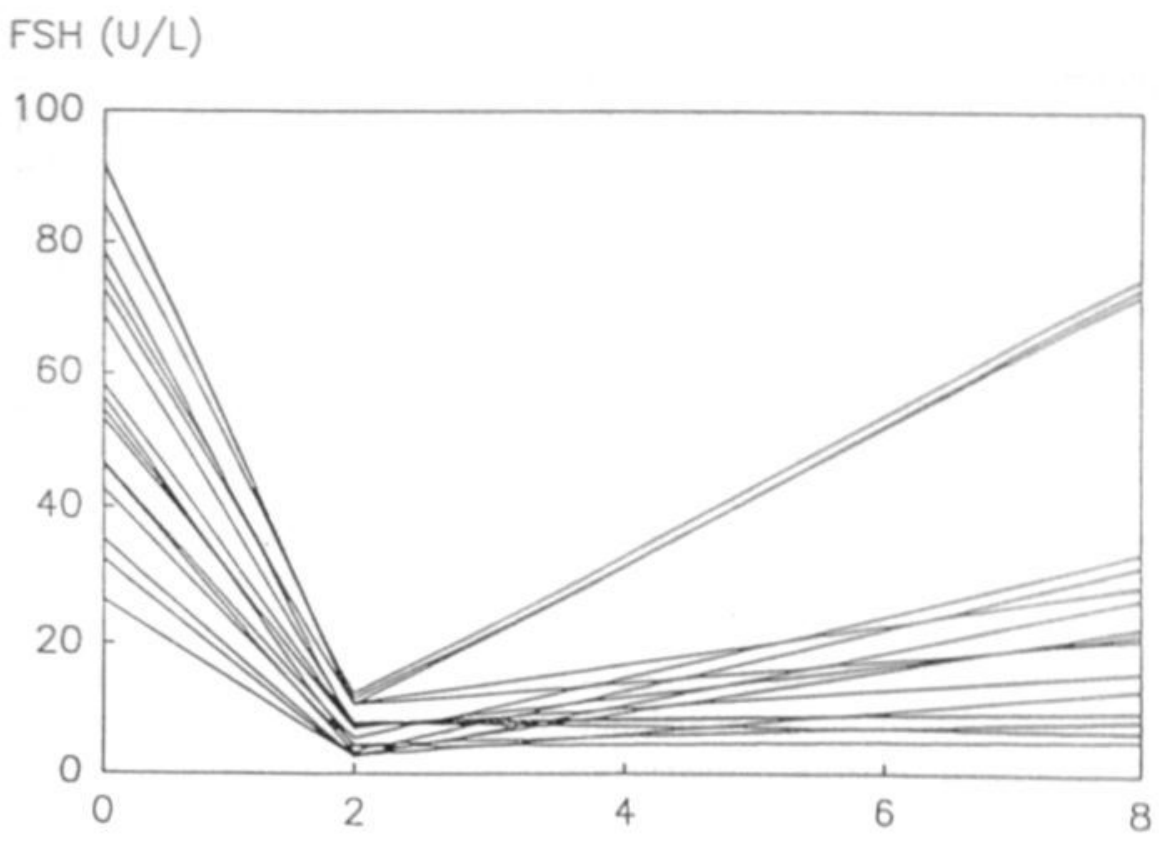

Fig. 2. FSH serum levels (U/L) in 17 postmenopausal women before, 2 and 8 weeks after the administration of a single depot-dose of the GnRHa triptorelin.

postmenopausal women $(\mathrm{P}<0.05)$. LH and FSH serum levels eight weeks after the administration of the GnRHa were the same in both groups.

When evaluating the effect of time after menopause on the LH and FSH serum levels, again, no statistical differences were noted for the E2 serum levels between both groups for all samples (Table 1). Serum levels of LH and FSH before and after administration of the GnRHa are shown in Table 2 and 3. Before treatment, both the LH and FSH serum levels were the same in both groups of patients. Two weeks after administration of the GnRHa, however, both $\mathrm{LH}$ and FSH were significantly higher in the group of patients $>15$ years after the menopause $(\mathrm{P}<0.05)$. Eight weeks after the administration of the GnRHa, the $\mathrm{LH}$ and FSH serum levels were the same in both groups.

\section{Discussion}

GnRHa has been used in premenopausal patients for various indications. Little information, however, is available on the administration of $\mathrm{GnRHa}$ in postmenopausal women. In postmenopausal women, GnRHa has been used in studies investigating the hormonal changes in the menopause $(3,4)$, and in studies investigating the possible role of LH in the etiology of hot flushes (5-7). GnRHa has also been used in phase- 2 studies 
of patients with advanced ovarian and breast carcinoma (8-14).

In all studies mentioned, GnRHa was administered either frequently or continuously. Hormonal data concerning discontinuation of a GnRHa are scarce, and the effect on gonadotropins after the administration of a single depot-dose of GnRHa in postmenopausal women has never been published before.

In the present study, a single depot-dose of triptorelin was given to 17 postmenopausal women. E2 serum levels were in the normal postmenopausal range for all samples, and no differences were found between groups when the patients were divided according to chronological age and time after menopause. Therefore, possible influences of differences in E2 serum levels on the LH and FSH basal levels, as well as the response of the pituitary to the GnRHa, or to endogenous LHRH during the recovery period which follows down-regulation can be excluded. Two weeks after medication, LH and FSH levels were reduced to $<25 \%$ of their initial serum concentration. This reduction is comparable with the effect of administration of a single depot-dose of triptorelin in premenopausal women during the early follicular and mid-luteal phase (1). Studies in premenopausal women have shown that LH and FSH are back to pre-GnRHa levels within 6 weeks after discontinuation of medication. In the study of Broekmans and coworkers, this was seen for FSH levels, but normal levels of LH were only found 8 weeks after administration of the GnRHa. In the present group of postmenopausal women 8 weeks after the administration of the single depot-dose, mean LH and FSH levels had increased again but were still significantly below the initial pre-GnRHa levels. In nine postmenopausal women, the LH serum levels decreased further between 2-8 weeks after administration of the GnRHa. This was found for FSH in only one patient. Three patients had normal FSH again 8 weeks after the administration of the GnRHa (Fig. 2). Two of these patients were older than 70 years. Their mean and median E2 levels for all samples were not different from all other patients. The question arises whether the slow recovery of LH and FSH is caused by a reduced release of hypothalamic GnRH, a decreased sensitivity of the pituitary gonadotroph cells, a persisting depletion of gonadotroph cell membrane GnRH receptors, or a difference in the bio-availability of triptorelin in postmenopausal women.

Few studies have been published describing gonadotropin secretion in the course of the postmenopause. After the onset of natural menopause, serum gonadotropin levels rise progressively because of the decline in negative feedback by ovarian steroids and inhibin. Several studies have noted secondary physiological decline in pituitary gonadotropin hypersecretion with advancing chronological age and time after the menopause (15-18). In the first decade after menopause, the LH and FSH serum levels have been noted to decrease already. Very limited information, however, exists about the precise mechanism of this neuroendocrine manifestation. It has been suggested that the mechanism accounting for the reduction in pituitary gonadotropin release may consist of both alterations in the episodic release pattern of hypothalamic GnRH and of changes in the pituitary gonadotroph responsiveness (18). It has also been postulated that ageing affects the secretory activity of either the pituitary gonadotroph cells or the GnRH neurons (17). 
Others have found no such age-related attenuation in gonadotropin release (19). In the present study, patients $\leq 67$ years old had no higher serum pre-GnRHa serum level of LH than patients $>67$ years old. The serum level of FSH was even significantly higher in the group of patients $>67$ years old $(\mathrm{P}<0.05)$. The effect, however, of the administration of a single depot-dose of the GnRHa triptorelin on $\mathrm{LH}$ and $\mathrm{FSH}$, as well as the recovery, was the same in both groups. Dividing the patients according to time interval from the last menstrual period, it appeared that, in contrast to other studies, there was no significant difference in the pre-GnRHa levels of LH and FSH in either group. The effect of a GnRHa in both groups was also the same.

From the present study we conclude that, in contrast to other studies, chronological age and time after menopause have no significant effect on the basal activity of the hypothalamus and the pituitary concerning gonadotropin production and release. We found that 2 weeks after the administration of a single depot-dose of the GnRHa triptorelin in postmenopausal women, the serum gonadotropin levels were suppressed to premenopausal levels. Eight weeks after the administration of the GnRHa the LH and FSH serum levels, although rising again, were still significantly lower than the initial levels. This is in contrast with premenopausal women. E2 can be excluded as a determining factor of this prolonged suppression, as can basic physiological activity of the hypothalamus and the pituitary. One possible mechanism which may be held responsible for the prolonged suppression is an attenuated replenishment of depleted pituitary cell membrane GnRH receptors in postmenopausal women.

\section{Acknowledgements}

We thank Ferring B.V., Haarlem, The Netherlands for their financial support and generous supply of the GnRHa triptorelin, and Dr FH de Jong, Department of Endocrinology and Reproduction, Erasmus University, Rotterdam, for performing the E2 assay.

\section{References}

1. Broekmans FJ, Bernardus RE, Berkhout G, Schoemaker J. Pituitary and ovarian suppression after early follicular and mid-luteal administration of a LHRH agonist in a depot formulation: Decapeptyl CR. Gynecol Endocrinol 1992;6:153- 61.

2. Happ J, Schultheiss H, Jacobi GH, Wenderoth UK, Buttenschön K, Miesel K, Spahn H, Hör G. Pharmacodynamics, pharmacokinetics and bioavailability of the prolonged LH-RH agonist Decapeptyl-SR. In: Hormonal manipulation of cancer: peptides, growth factors and new (anti) steroidal agents. Klijn JGM et al, eds. Raven Press, New York 1987; 249-53.

3. Bergquist $\mathrm{C}$, Nillius $\mathrm{SJ}$, Wide $\mathrm{L}$. Reduced gonadotropin secretion in postmenopausal women during treatment with a stimulatory LRH analogue. J Clin Endocrinol Metab 1979;49: 472-4.

4. Dowsett M, Cantwell B, Lal A, Jeffcoate SL, Harris AL. Suppression of postmenopausal ovarian steroidogenesis with the luteinizing hormone-releasing hormone agonist goserelin. J Clin Endocrinol Metab 1988;66:672-7. 
5. Casper RF, Yen SSC. Menopausal flushes: effect of pituitary gonadotropin desensitization by a potent luteinizing hormone-releasing factor agonist. J Clin Endocrinol Metab 1981;53:1056-8.

6. Lightman SL, Jacobs HS, Maguire AK. Down-regulation of gonadotrophin secretion in postmenopausal women by a superactive LHRH analogue: lack of effect on menopausal flushing. Br J Obstet Gynaecol 1982;89:977-80.

7. Shaw RW, Kerr-Wilson RHJ, Fraser HM, McNeilly AS, Howie PW, Sandow J. Effect of an intranasal LHRH agonist on gonadotrophins and hot flushes in postmenopausal women. Maturitas 1985;7:1617.

8. Waxman JH, Harland SJ, Coombes RC, Wrigley PFM, Malpas JS, Powles T, Lister TA. The treatment of postmenopausal women with advanced breast cancer with buserelin. Cancer Chemother Pharmacol 1985;15:171-3.

9. Plowman PN, Nicholson RI, Walker KJ. Remission of postmenopausal breast cancer during treatment with the luteinising hormone releasing hormone agonist ICI 118630. Br J Cancer 1986;54:903-9.

10. Parmar H, Rustin G, Lightman SL, Phillips RH, Hanham IW, Schally AV. Response to D-Trp-6luteinising hormone releasing hormone (Decapeptyl) microcapsules in advanced ovarian cancer. Br Med J Clin Res 1988;296:1229.

11. Parmar H, Phillips RH, Rustin G, Lightman SL, Schally AV. Therapy of advanced ovarian cancer with D-Trp-6-LH-RH (decapeptyl) microcapsules. Biomed Pharmacother 1988;42: 531-8.

12. Dowsett M, Cantwell BMJ, Harris AL. Endocrinology of Zoladex in postmenopausal women. Horm Res 1989;32(Suppl.): 209-12.

13. Harris AL, Carmichael J, Cantwell BMJ, Dowsett M. Zoladex: therapeutic effects in postmenopausal breast cancer. Horm Res 1989;32(Suppl.):213-7.

14. Harris AL, Carmichael J, Cantwell BMJ, Dowsett M. Zoladex: endocrine and therapeutic effects in postmenopausal breast cancer. Br J Cancer 1989;59:97-9.

15. Chakravarti S, Collins WP, Forecast JD, Newton JR, Oram DH, Studd JWW. Hormonal profiles after the menopause. Br Med J 1976;2:784-7.

16. Studd JWW, Collins WP, Chakravarti S. Plasma hormone profiles after the menopause and bilateral oophorectomy. Postgrad Med J 1978;54(Suppl.):25-30.

17. Kwekkeboom DJ, de Jong FH, van Hemert AM, Vandenbroucke JP, Valkenbug HA, Lamberts SWJ. Serum gonadotropins and $\alpha$-subunit decline in aging normal postmenopausal women. J Clin Endocrinol Metab 1990;70:944-50.

18. Rossmanith WG, Scherbaum WA, Lauritzen C. Gonadotropin secretion during aging in postmenopausal women. Neuroendocrinol 1991;54:211-8.

19. Scaglia H, Medina M, Pinto-Ferreira AL, Vázques G, Gual C, Pérez-Palacios G. Pituitary LH and FSH secretion and responsiveness in women of old age. Acta Endocrinol 1976;81: 673-9. 


\title{
CHAPTER 4
}

\author{
SECTION I
}

\section{ENDOCRINE ACTIVITY OF THE POSTMENOPAUSAL OVARY: THE EFFECTS OF PITUITARY DOWN-REGULATION AND OOPHORECTOMY}

\begin{abstract}
Alexander V. Sluijmer ${ }^{1,3}$, Maas Jan Heineman', Frank H. de Jong ${ }^{2}$, and Johannes L.H. Evers ${ }^{3}$.
\end{abstract}

Department of Obstetrics and Gynecology, De Wever Ziekenhuis, Heerlen'; Department of Endocrinology and Reproduction, Erasmus Universiteit, Rotterdam²; Department of Obstetrics and Gynecology, Academisch Ziekenhuis Maastricht, The Netherlands ${ }^{3}$ 


\section{Abstract}

The endocrine activity of the postmenopausal ovary and the effect of pituitary down-regulation were studied in a group of 35 postmenopausal women. All women underwent oophorectomy with or without hysterectomy. Fifteen women received a single dose of a depot $\mathrm{GnRH}$ agonist (GnRHa) 2 weeks before operation, whereas 20 women formed the control group. Peripheral venous levels of LH, FSH, estrone, 17ß-estradiol, testosterone (T), androstenedione (A), sex hormone-binding globulin, and dehydroepiandrosterone sulfate were measured 2 weeks before, during, and 6 weeks after surgery. Ovarian venous blood was sampled during surgery.

In the GnRHa and control groups, ovarian venous levels of $\mathrm{A}$ and $\mathrm{T}$ were significantly higher, and those of dehydroepiandrosterone sulfate and sex hormone-binding globulin significantly lower, compared to the peripheral levels. A significant decrease in $\mathrm{T}$ was found in the peripheral and ovarian vein samples during pituitary downregulation with $\mathrm{GnRHa}$. Six weeks after operation, peripheral $\mathrm{T}$ levels were significantly lower than those during surgery in the group that was down-regulated at the time of oophorectomy.

We conclude that the postmenopausal ovary produces significant amounts of A and $\mathrm{T}$, although only $\mathrm{T}$ contributes significantly to its peripheral serum levels. $\mathrm{T}$ production by the postmenopausal ovary is in part stimulated by the high levels of circulating gonadotropins, although pituitary down-regulation does not completely abolish androgenic activity.

\section{Introduction}

Early studies on the endocrine function of the postmenopausal ovary have shown conflicting results (1-6). This may be the result of variation in patient population, laboratory methods applied, and parameters investigated. Some studies have postulated that high postmenopausal gonadotropin concentrations stimulate ovarian androgen production $(4,7)$. No studies have been published to corroborate this suggestion.

Only a few recent papers have addressed the steroidogenic function of the postmenopausal ovary. Lucisano et al. (8) concluded that the postmenopausal ovary continues to produce androgens and can be a potential source of estrogens and progesterone. Dowsett et al. (9) found a significant decrease in peripheral serum levels of 17Bestradiol (E2), androstenedione (A), and especially testosterone (T) 4 weeks after the administration of a GnRH agonist (GnRHa). Recently, the endocrine function of the postmenopausal ovary was reviewed (10).

The aim of the present investigation was to study the effect of administration of a depot GnRHa and oophorectomy on circulating hormone levels in postmenopausal women and to determine the endocrine activity of the postmenopausal ovary by measuring hormone levels in peripheral (antecubital vein) and ovarian venous blood. 


\section{Subjects and methods}

Ovarian function was investigated in 35 postmenopausal women, who underwent laparotomy for various gynecological disorders. All women had had their last menstrual period more than 12 months before operation; none had received estrogen replacement therapy for at least 6 months preceding the investigation. The clinical data are summarized in Table 1. The study was approved by the hospital ethics committee. All patients gave written informed consent.

From all patients, blood was taken from a peripheral vein 2 weeks before surgery. Subsequently, the patients were assigned alternatingly to 1 of 2 groups. The control group consisted of 20 patients who received no medication. The $\mathrm{GnRHa}$ group originally also consisted of 20 patients who received a $3.75-\mathrm{mg}$ im injection of the GnRHa triptorelin (Decapeptyl-CR, D-Trp ${ }^{6}$ GnRH in biodegradable micro-capsules, Ferring, Haarlem, The Netherlands).

Table 1. Clinical data of 35 postmenopausal women undergoing oophorectomy with or without hysterectomy.

Control group

$(n=20)$
GnRHa group

$(n=15)$

$\begin{array}{lll}\text { Age }(\mathrm{yr}) & 60.0(52-81) & 67.0(54-81) \\ \text { Yrs since menopause } & 10.5(1-32) & 15.0(1-29) \\ \mathrm{Wt}(\mathrm{kg}) & 73.3(52.0-107.5) & 69.0(57.5-98.8) \\ \mathrm{Ht}(\mathrm{m}) & 1.60(1.47-1.74) & 1.60(1.56-1.69) \\ \text { Body mass index }(\mathrm{kg} / \mathrm{m} 2) & 27.5(20.1-42.5) & 27.3(21.6-36.3) \\ \text { Indication for surgery } & & \\ \quad \text { Endometrial carcinoma } & 13 & 8 \\ \quad \text { Endometrial atypia } & 3 & 3 \\ \quad \text { Endocervical atypia } & 0 & 1 \\ \quad \text { Leiomyoma uterus } & 2 & 3 \\ \quad \text { Ovarian cyst } & 2 & 0\end{array}$

Numerical data are shown as medians, with the range in parenthesis.

Mann-Whitney U test: no statistical differences were noted for age, years after menopause, weight, height, or body mass index between the control group and the GnRHa group.

Five patients had to be excluded from this group due to sampling problems (11), inappropriate administration of GnRHa, and granulosa cell tumor of the ovary (12). A significant decrease in serum LH and FSH levels within 2 weeks after the single administration of the same depot GnRHa was noted in a previous study in postmenopausal 
women (13). At the time of surgery, blood was again taken from a peripheral vein and from the ovarian veins according to a method described previously (11). All patients had macroscopically normal ovaries. Six weeks after operation, i.e. 8 weeks after triptorelin administration, a final sample of peripheral blood was obtained. This time was chosen because in premenopausal women the peripheral serum gonadotropin levels had returned to pretreatment levels 8 weeks after the administration of a single $3.75-\mathrm{mg}$ depot-dose of triptorelin (14).

Blood samples were allowed to clot after collection. The collected serum was stored at $-20^{\circ} \mathrm{C}$ until assayed.

Serum levels of LH, FSH, estrone (E1), E2, A, T, sex hormone-binding globulin (SHBG), and dehydroepiandrosterone sulfate (DHEAS) were measured. LH and FSH were assayed using an immunofluorometric assay (Delfia, Pharmacia, Woerden, The Netherlands) with IS $80 / 552$ and IRP 78/549 as the respective standards. E1 and T were measured by RIA, as described previously $(15,16)$. E2, A, and DHEAS levels were measured using RIA kits (Diagnostic Products Corp., Los Angeles, CA), and SHBG was estimated using a two-site immunoradiometric assay from the same supplier.

The detection limit, defined as the value that is $2 \mathrm{SD}$ above the mean of zero standard measurement values, of the Delfia human LH and human FSH assay was 0.05 U/L. The sensitivities of the other assays were: E1, $20 \mathrm{pmol} / \mathrm{L} ; \mathrm{E} 2,4 \mathrm{pmol} / \mathrm{L} ; \mathrm{A}, 0.1$ $\mathrm{nmol} / \mathrm{L} ; \mathrm{T}, 0.2 \mathrm{nmol} / \mathrm{L}$; SHBG, $1 \mathrm{nmol} / \mathrm{L}$; and DHEAS, $0.5 \mu \mathrm{mol} / \mathrm{L}$.

Intra- and interassay coefficients of variation were both less than $7.5 \%$ for $\mathrm{LH}$; both less than $5 \%$ for $\mathrm{FSH}$; less than $14 \%$ and $19 \%$, respectively, for the E1 assay; less than $15 \%$ and $19 \%$ for the E2 assay, respectively; less than $11 \%$ and $17 \%$ for the A assay, respectively; less than $3 \%$ and $5 \%$ for the T assay, respectively; less than $4 \%$ and $5 \%$ for the SHBG assay, respectively; and less than $4 \%$ and $6 \%$ for the DHEAS assay, respectively.

To exclude possible artifacts caused by mixing the ovarian venous blood with other fluids, such as peritoneal fluid, during sampling, immunoglobulin M (IgM) levels were estimated in the peripheral and ovarian veins, collected at the time of surgery, in five patients. IgM is a relatively stable protein, which can be measured accurately and is not metabolized by the ovary. IgM was measured using a single radial immunodiffusion technique in an agarose-gel layer (LC-Partgen IgM, Behringwerke, Marburg, Germany). The assay was standardized against an in-house protein standard. The intra- and interassay coefficients of variation were less than $15 \%$.

On the assumption that the GnRHa and control groups would not show a normal distribution of results, we performed non-parametric statistical testing. The Wilcoxon matched pairs sign rank test was used for statistical analysis of differences in serum hormone levels between individual blood samplings. The Mann-Whitney U test was used for statistical analysis of the influence of GnRHa administration on serum hormone levels at various sampling moments. 


\section{Results}

The mean serum hormone levels at all sampling points are summarized in Figs. 1-3. Because no normal distribution may be assumed, the median values and ranges of all serum hormone levels used for statistical analysis by nonparametric tests are indicated in the text.

In the GnRHa group, serum levels of LH and FSH (Fig. 1) were significantly suppressed to premenopausal levels 2 weeks after the administration of a single depotdose of triptorelin [LH: median, $5.7 \mathrm{IU} / \mathrm{L}$ (range, 2.8-11.8) vs. 26.6 IU/L (range, 11.040.8); FSH: $7.4 \mathrm{IU} / \mathrm{L}$ (range, 2.6-12.5] vs. $54.5 \mathrm{IU} / \mathrm{L}$ (range, 26.5-91.9)].

No significant differences were noted between the left and right ovarian venous levels of E1, E2, A, T, SHBG, and DHEAS. Therefore, the mean of these two concentrations for each patient was used for further calculations. If blood was obtained from only one ovarian vein, the value for this sample was used.

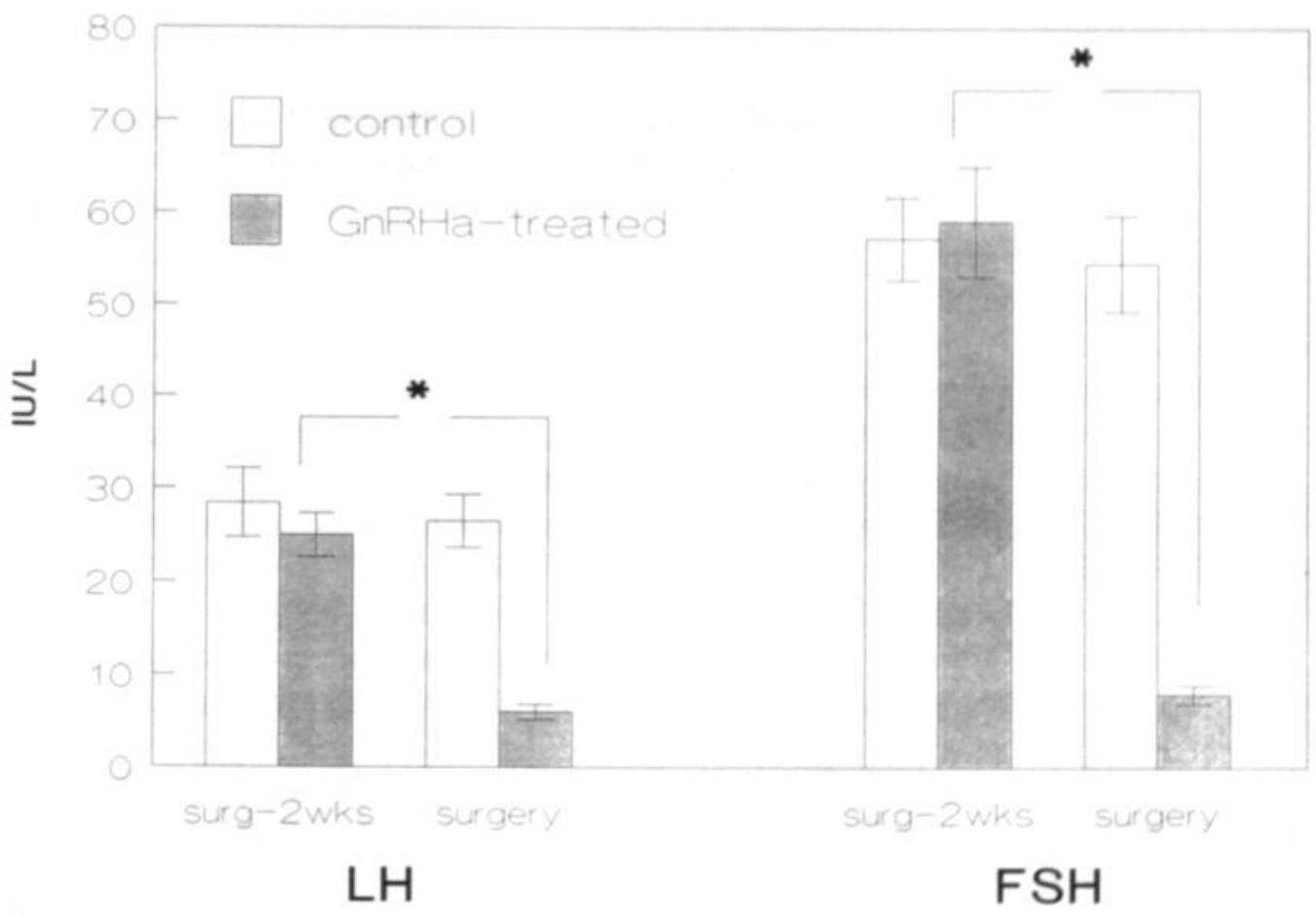

Fig. 1 Mean peripheral serum levels ( \pm S.E.M.) of LH and FSH in control and GnRHa-treated postmenopausal women, 2 weeks before surgery and at the time of surgery $(* P<0.0001)$. 


\section{Control group}

Hormone levels in the peripheral serum sample taken 2 weeks before surgery were not different from those collected at the time of surgery (Fig. 2). Six weeks after operation, peripheral venous levels of E1, E2, and T were significantly lower than those before operation [E1: $147 \mathrm{pmol} / \mathrm{L}$ (range, 3-300) vs. $180 \mathrm{pmol} / \mathrm{L}$ (range, 10-405); E2: $58 \mathrm{pmol} / \mathrm{L}$ (range, $11-151$ ) vs. $62 \mathrm{pmol} / \mathrm{L}$ (range, $26-195$ ); $\mathrm{T}: 1.0 \mathrm{nmol} / \mathrm{L}$ (range, $0.5-3.4$ ) vs. $1.6 \mathrm{nmol} / \mathrm{L}$ (range, $0.8-7.7$ )].

In five patients, IgM levels were measured in peripheral and ovarian venous blood, obtained at the time of surgery. No significant differences were found [ovarian vein: 1.1 $\mathrm{g} / \mathrm{L}$ (range, 0.3-1.7); peripheral vein: $1.2 \mathrm{~g} / \mathrm{L}$ (range, 0.4-2.1)].

No peripheral-ovarian venous concentration differences were found for E1 and E2 (Fig. 3). The ovarian venous levels of $A$ and $T$ were higher than the peripheral venous levels obtained at the time of surgery [A: $11.7 \mathrm{nmol} / \mathrm{L}$ (range, 3.8-31.2) vs. $5.4 \mathrm{nmol} / \mathrm{L}$ (range, $2.1-19.4$ ); $\mathrm{T}: 3.3 \mathrm{nmol} / \mathrm{L}$ (range, $1.3-41.1$ ) vs. $1.8 \mathrm{nmol} / \mathrm{L}$ (range, $0.8-4.1$ )]. The levels of SHBG and DHEAS were lower in the ovarian vein than in the peripheral vein during surgery [SHBG: $39.6 \mathrm{nmol} / \mathrm{L}$ (range, 13.6-77.3) vs. $44.0 \mathrm{nmol} / \mathrm{L}$ (range, 15.897.6); DHEAS: $2.5 \mu \mathrm{mol} / \mathrm{L}$ (range, $0.3-10.4$ ) vs. $3.5 \mu \mathrm{mol} / \mathrm{L}$ (range, $0.5-13.4$ )].

\section{GnRHa group}

The peripheral venous T level (Fig. 2) was reduced at the time of surgery compared with the level in the peripheral vein before the administration of $\mathrm{GnRHa}[1.4 \mathrm{nmol} / \mathrm{L}$ (range, 0.6-1.9) vs. $1.5 \mathrm{nmol} / \mathrm{L}$ (range, 0.6-3.0)]. Peripheral venous levels of E1, E2, A, SHBG, and DHEAS were not influenced by pituitary down-regulation. Six weeks after operation, the peripheral venous $\mathrm{T}$ level was decreased even further compared to that during operation [1.0 nmol/L (range, $0.5-1.7$ ) vs. $1.4 \mathrm{nmol} / \mathrm{L}$ (range, 0.6-1.9)].

The ovarian venous levels of $\mathrm{A}$ and $\mathrm{T}$ were higher than the peripheral venous levels during operation [A: $10.8 \mathrm{nmol} / \mathrm{L}$ (range, 3.0-24.6) vs. $4.5 \mathrm{nmol} / \mathrm{L}$ (range, 2.08.0 ); T: $2.1 \mathrm{nmol} / \mathrm{L}$ (range, $0.7-6.6$ ) vs. $1.4 \mathrm{nmol} / \mathrm{L}$ (range, $0.6-1.9$ )]. The ovarian venous levels of SHBG and DHEAS were lower than the peripheral venous levels during operation [SHBG: $55.8 \mathrm{nmol} / \mathrm{L}$ (range, 20.0-110.8) vs. $64.8 \mathrm{nmol} / \mathrm{L}$ (range, 25.7-127.2); DHEAS: $2.4 \mu \mathrm{mol} / \mathrm{L}$ (range, 1.1-6.4) vs. $3.2 \mu \mathrm{mol} / \mathrm{L}$ (range, 1.3-8.9)].

The effect of pituitary down-regulation on endocrine function was also studied by comparing hormone levels in the control and GnRHa groups at the same sampling times (Fig. 3).

For $\mathrm{T}$, the peripheral and ovarian venous serum levels were lower in the GnRHa group than in the control group at the time of surgery [peripheral vein: $1.4 \mathrm{nmol} / \mathrm{L}$ (range, $0.6-1.9$ ) vs. $1.8 \mathrm{nmol} / \mathrm{L}$ (range, $0.8-4.1$ ) ; ovarian vein: $2.1 \mathrm{nmol} / \mathrm{L}$ (range, 0.7 6.6 ) vs. $3.3 \mathrm{nmol} / \mathrm{L}$ (range, 1.3-41.1)]. The peripheral and ovarian venous serum levels of SHBG during operation were higher in the GnRHa group than in the control group [peripheral vein: $64.8 \mathrm{nmol} / \mathrm{L}$ (range, 25.7-127.2) vs. $44.0 \mathrm{nmol} / \mathrm{L}$ (range, 15.8-97.6); ovarian vein: $55.8 \mathrm{nmol} / \mathrm{L}$ (range, $20.0-110.8$ ) vs. $39.6 \mathrm{nmol} / \mathrm{L}$ (range, 13.6-77.3)]. No further significant differences were found. 

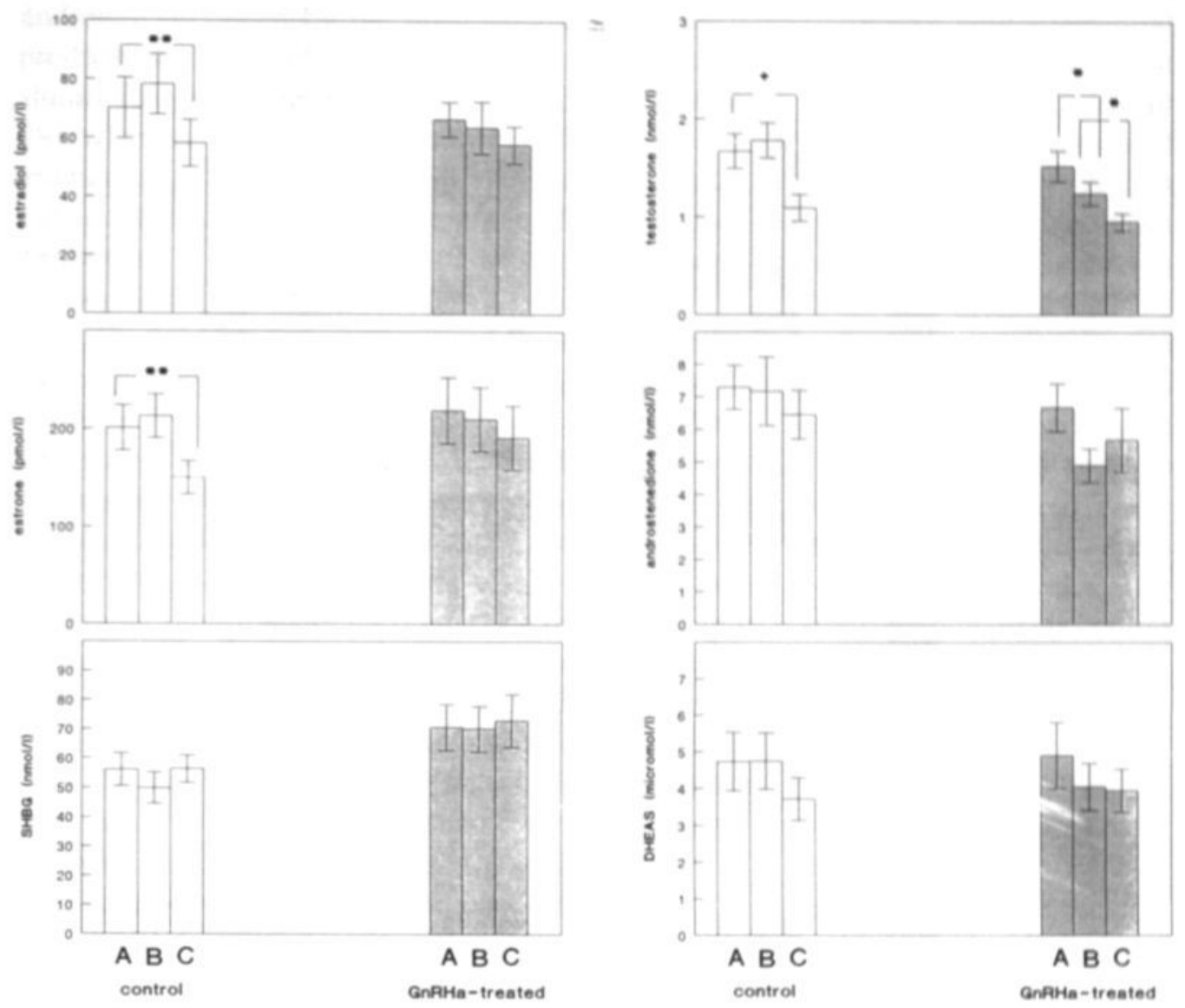

Fig. 2 Mean peripheral serum levels ( \pm S.E.M.) of steroids and SHBG in control and GnRHa-treated postmenopausal women 2 weeks before surgery $(A)$, at the time of surgery $(B)$, and 6 weeks after surgery $(C)(*: P<0.05 ; *: P<0.01 ;+: P<0.0001)$

\section{Discussion}

Many studies have been performed to determine the endocrine function of postmenopausal ovaries. The results of these studies, however, are conflicting.

Early studies demonstrated the steroidogenic potential of the postmenopausal ovary. The presence of steroid-specific enzymes in ovarian stromal tissue was demonstrated by enzyme histochemical techniques $(7,17,18)$. In vitro incubation studies demonstrated the ability of postmenopausal ovaries to convert various precursor steroids to androgens and indicated that the principal steroid produced is $\mathrm{A}$, in addition to smaller quantities of $\mathrm{T}$ and DHEA $(1,19,20)$. In these studies, no signs of aromatizing enzyme activity were found. Dennefors et al. (21), however, found aromatase activity in ovarian stromal tissue and showed that the postmenopausal ovary can produce substantial amounts of $\mathrm{E} 1$ in vitro. 


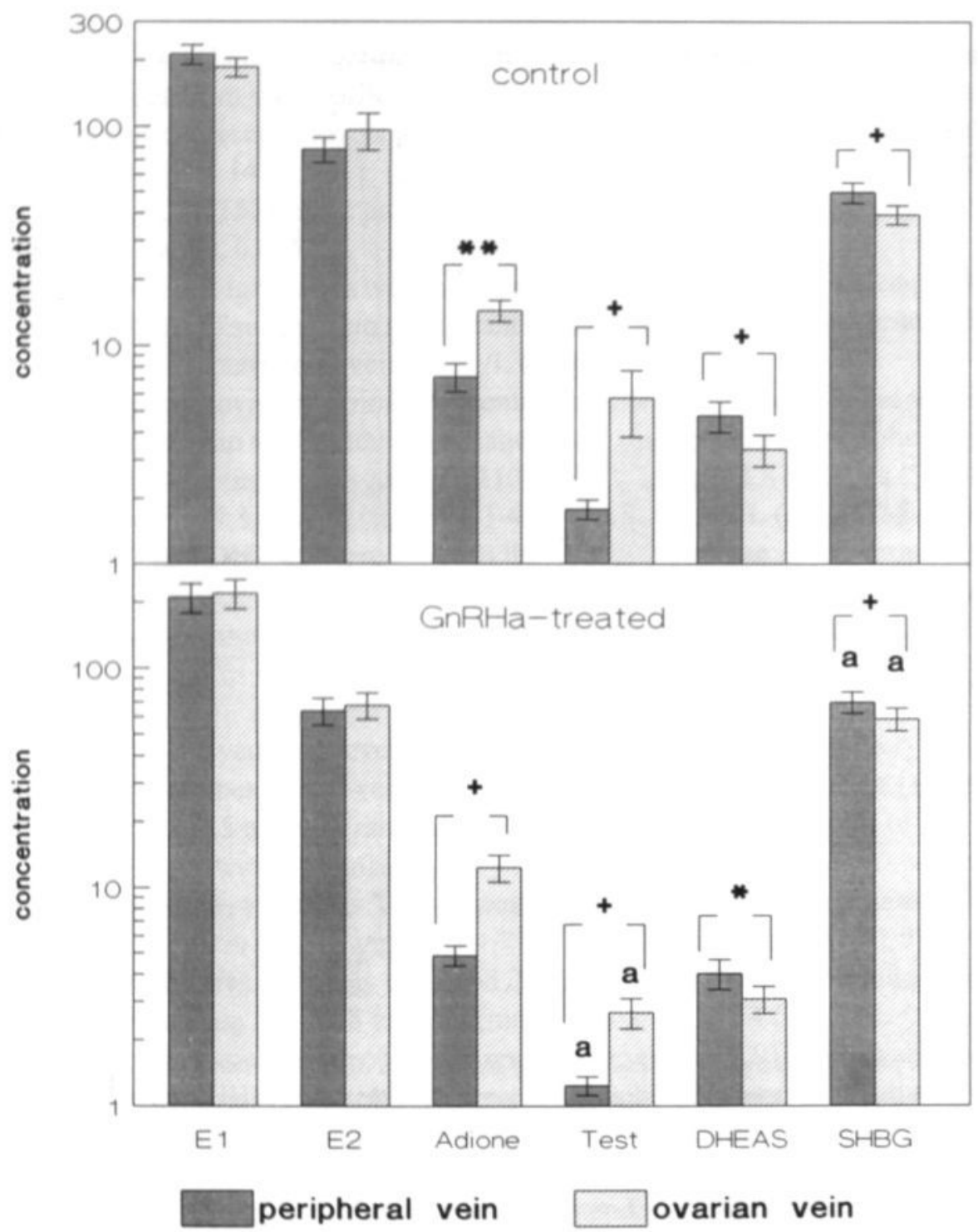

Fig. 3 Mean peripheral and ovarian venous serum levels ( \pm S.E.M.) of steroids and SHBG in control and GnRHa-treated postmenopausal women at the time of surgery $(*: P<0.01 ; * *: P<0.001 ;+$ : $P<0.0001)$. Significant differences between corresponding sampling moments in the control and GnRHa-treated women are also indicated ( $a$ : $P<0.05)$.

In many studies, peripheral and/or ovarian venous hormone levels were measured with or without oophorectomy. Although some studies found that $\mathrm{T}$ was the major androgen secreted by the postmenopausal ovary $(2-5,9)$, other researchers did not observe any decrease in peripheral levels of $\mathrm{T}$ after oophorectomy $(22,23)$. In all of these studies, except that by Loncope et al. (5), it was found that smaller amounts of A were 
produced as well. In contrast, Greenblatt et al. (6) concluded that A was the principal androgen produced by the postmenopausal ovary. Some studies found substantial production of E1 and E2 by the postmenopausal ovary $(5,6,8,24,25)$. However, most studies found no or only minimal E2 production by the postmenopausal ovary $(2,4,21,26-$ 29 ), whereas most of the serum level of E1 appeared to be derived from the peripheral aromatization of $A$ that occurs preferentially in fat and muscle tissue $(26,30-33)$. It is now generally accepted that circulating E2 in postmenopausal women is derived from peripheral conversion of $\mathrm{E} 1$ and $\mathrm{T}$, and the postmenopausal ovary and adrenal glands do not contribute directly to the plasma E2 level (32).

In this study we investigated the steroid production of postmenopausal ovaries by comparing the effects of $\mathrm{GnRHa}$ and oophorectomy on peripheral and ovarian venous hormone levels. A comparison of the peripheral and ovarian venous steroid levels in the GnRHa and control groups showed that the postmenopausal ovary produces $\mathrm{T}$ and $\mathrm{A}$ in considerable amounts. Six weeks after operation, the peripheral serum level of $\mathrm{T}$ was significantly lower than the preoperative serum level. This indicates that the steroid production of $\mathrm{T}$ by the postmenopausal ovary contributes to the peripheral level. T may be used as a substrate for the production of E2 by peripheral aromatization. In the control group, the peripheral serum level of E2 (and E1) was significantly lower after operation. In the GnRHa women, however, the difference between E1 and E2 serum levels before and after operation were similar, but did not reach significance.

In both the GnRHa and control groups, the ovarian venous SHBG and DHEAS levels were significantly lower than the peripheral venous levels of these compounds. A sampling error was excluded as a reason for this observation, because no peripheralovarian gradient for IgM could be established. Because of differences in orders of magnitude (DHEAS circulates in micromole quantities), a contribution of DHEAS to the production of other ovarian steroids is difficult to investigate. Utilization of SHBG by the prostate (34) and endometrium (35) has been described in recent publications.

We have to consider that the ovarian veins not only drain the ovary, but also collect part of the venous effluent from the uterus. It remains to be elucidated whether DHEAS is metabolized by pelvic tissues, e.g. endometrium. In our study the peripheral and ovarian venous serum levels of SHBG were higher in the GnRHa group than in the control group at all sampling moments. The reason for this difference remains unclear.

Many researchers have suggested that steroid production in the postmenopausal ovaries is stimulated by the high endogenous gonadotropin levels. Some authors found increased peripheral steroid levels after stimulation of postmenopausal women with hCG $(4,7)$. Dowsett et al. (9) found a significant decrease in $\mathrm{T}$ after the administration of a GnRHa. In their study, only peripheral venous serum hormone levels were investigated in patients with advanced breast cancer. Others, however, found no changes in serum steroid levels after the administration of a GnRHa $(36,37)$. The effect of GnRHa on $\mathrm{T}$ production in this study, measured in both peripheral and ovarian veins, illustrates that the postmenopausal ovary is influenced by gonadotropins. For A, no such effect was found, probably because of the relatively large adrenal contribution to circulating A levels. 
In conclusion, 1) the postmenopausal ovary produces significant amounts of A and $\mathrm{T}$, although only $\mathrm{T}$ contributes significantly to its peripheral serum levels; and, 2) T production by the postmenopausal ovary is in part stimulated by the high levels of circulating gonadotropins, although pituitary down-regulation does not completely abolish androgenic activity.

\section{Acknowledgements}

We thank Dr. P.P.C.A. Menheere and M. Haesen-Meers, Academisch Ziekenhuis Maastricht (Maastricht, The Netherlands), for performing the IgM assays, and Dr. R. de Leeuw, Organon International (Oss, The Netherlands), for performing the gonadotropin assays. We also thank Ferring (Haarlem, The Netherlands) for their generous supply of the GnRHa triptorelin.

\section{References}

1. Mattingly RF, Huang WY. Steroidogenesis of the menopausal and postmenopausal ovary. Am J Obstet Gynecol 1969;103:679-93.

2. Judd HL, Judd GE, Lucas WE, Yen SSC. Endocrine function of the postmenopausal ovary: concentration of androgens and estrogens in ovarian and peripheral vein blood. J Clin Endocrinol Metab 1974;39:1020-4.

3. Judd HL, Lucas WE, Yen SSC. Effect of oophorectomy on circulating testosterone and androstenedione levels in patients with endometrial cancer. Am J Obstet Gynecol 1974;118:793-8.

4. Vermeulen A. The hormonal activity of the postmenopausal ovary. J Clin Endocrinol Metab $1976 ; 42: 247-53$.

5. Longcope C, Hunter R, Franz C. Steroid secretion by the postmenopausal ovary. Am J Obstet Gynecol 1980;138:564-8.

6. Greenblatt RB, Colle ML, Mahesh VB. Ovarian and adrenal steroid production in the postmenopausal woman. Obstet Gynecol 1976;47:383-7.

7. Poliak A, Jones GES, Goldberg B, Solomon D, Woodruff JD. Effect of human chorionic gonadotropin on postmenopausal women. Am J Obstet Gynecol 1968;101:731-9.

8. Lucisano A, Acampora MG, Russo N, Maniccia E, Montemurro A, Dell'Acqua S. Ovarian and peripheral plasma levels of progestogens, androgens and oestrogens in postmenopausal women. Maturitas 1984;6:45-53.

9. Dowsett M, Cantwell B, Lal A, Jeffcoate SL, Harris AL. Suppression of postmenopausal ovarian steroidogenesis with the luteinizing hormone-releasing hormone agonist goserelin. J Clin Endocrinol Metab 1988;66:672-7. 
10. Adashi EY. The climacteric ovary as a functional gonadotropin-driven androgen-producing gland. Fertil Steril 1994; 62:20-7.

11. Heineman MJ, Sluijmer AV, Evers JLH. Utero-ovarian vein blood sampling in postmenopausal women. Fertil Steril 1993;60:184-6.

12. Sluijmer AV, Heineman MJ, Evers JLH, de Jong FH. Peripheral vein, ovarian vein and ovarian tissue levels of inhibin in a postmenopausal patient with a granulosa cell tumour. Acta Endocrinol 1993:129:311-4.

13. Sluijmer AV, Heineman MJ, De Leeuw R, Evers JLH. Pituitary down-regulation with a single depot-dose of a GnRH agonist (Triptorelin) in postmenopausal women. Maturitas 1994;20:45-51.

14. Broekmans FJ, Bernardus RE, Berkhout G, Schoemaker J. Pituitary and ovarian suppression after early follicular and mid-luteal administration of a LHRH agonist in a depot formulation: Decapeptyl CR. Gynecol Endocrinol 1992;6: 153-61.

15. Kwekkeboom DJ, de Jong FH, van Hemert AM, Vandenbroucke JP, Valkenburg HA, Lamberts SWJ. Serum gonadotropins and $\alpha$-subunit decline in aging normal postmenopausal women. J Clin Endocrinol Metab 1990;70:944-50.

16. Verjans HL, Cooke BA, de Jong FH, de Jong CMM, van der Molen HJ. Evaluation of a radioimmunoassay for testosterone estimation. J Steroid Biochem 1973;4:665-76.

17. Fienberg R. The stromal theca celi and postmenopausal endometrial adenocarcinoma. Cancer $1969 ; 24: 32-8$.

18. Novak ER, Goldberg B, Jones GS, O'Toole RV. Enzyme histochemistry of the menopausal ovary associated with normal and abnormal endometrium. Am J Obstet Gynecol 1965;93: 669-82.

19. Plotz EJ, Wiener M, Stein AA, Hahn BD. Enzymatic activities related to steroidogenesis in postmenopausal ovaries of patients with and without endometrial carcinoma. Am J Obstet Gynecol 1967;99:182-97.

20. Schenker JG, Polishuk WZ, Eckstein B. Pathways in the biosynthesis of androgens in the postmenopausal ovary in vitro. Acta Endocrinol 1971;66:325-32.

21. Dennefors BL, Janson PO, Knutson F, Hamberger L. Steroid production and responsiveness to gonadotropin in isolated stromal tissue of human postmenopausal ovaries. Am J Obstet Gynecol 1980;136:997-1002.

22. Barlow JJ, Emerson K, Saxena BN. Estradiol production after ovariectomy for carcinoma of the breast. N Engl J Med 1969;280:633-7.

23. Abraham GE, Lobotsky J, Lloyd CW. Metabolism of testosterone and androstenedione in normal and ovariectomized women. J Clin Invest 1969;48:696-703.

24. McBride JM. Estrogen excretion levels in the normal postmenopausal woman. J Clin Endocrinol Metab 1957;17:1440-7.

25. Paulsen CA, Leach RB, Sandberg H, Sheinfeld S, Maddock WO. Function of the postmenopausal ovary. Comparison of urinary estrogen and gonadotropin excretion and response to administration of FSH in postmenopausal and ovariectomized women. J Am Geriatrics Soc 1958;6:803-13. 
26. Grodin JM, Siteri PK, MacDonald PC. Source of estrogen production in postmenopausal women. J Clin Endocrinol Metab 1973;36:207-14.

27. Longcope C. Metabolic clearance and blood production rates of estrogens in postmenopausal women. Am J Obstet Gynecol 1971;111:778-81.

28. Judd HL, Lucas WE, Yen SSC. Serum 17ß-estradiol and estrone levels in postmenopausal women with and without endometrial cancer. J Clin Endocrinol Metab 1976;43:272-8.

29. Rader MD, Flickinger GL, deVilla GO, Mikuta JJ, Mikhail G. Plasma estrogens in postmenopausal women. Am J Obstet Gynecol 1973;116:1069-73.

30. MacDonald PC, Edman CD, Hemsell DL, Porter JC, Siiteri PK. Effect of obesity on conversion of plasma androstenedione to estrone in postmenopausal women with and without endometrial cancer. Am J Obstet Gynecol 1978;130:448-55.

31. Schindler AE, Ebert A, Friedrich E. Conversion of androstenedione to estrone by human fat tissue. J Clin Endocrinol Metab 1972;35:627-30.

32. Siiteri PK. Postmenopausal estrogen production. In: van Keep PA, Lauritzen C, eds. Front Hormone Res (Karger,Basel) 1975;3:40-5.

33. Rizkallah TH, Tovell HMM, Kelly WG. Production of estrone and fractional conversion of circulating androstenedione to estrone in women with endometrial carcinoma. J Clin Endocrinol Metab 1975;40:1045-56.

34. Sakiyama R, Pardridge WM, Musto NA. Influx of testosterone-binding globulin (TeBG) and TeBGbound sex steroid hormones into rat testis and prostate. J Clin Endocrinol Metab 1988;67:98-103.

35. Noé G, Cheng YC, Dabiké M, Croxatto HB. Tissue uptake of human sex hormone-binding globulin and its influence on ligand kinetics in the adult female rat. Biol Reprod 1992; 47:970-6.

36. Plowman PN, Nicholson RI, Walker KJ. Remission of postmenopausal breast cancer during treatment with the luteinising hormone releasing hormone agonist ICI 118630. Br J Cancer 1986;54:903-9.

37. Waxman JH, Harland SJ, Coombes RC, Wrigley PFM, Malpas JS, Powles T, Lister TA. The treatment of postmenopausal women with advanced breast cancer with buserelin. Cancer Chemother Pharmacol 1985;15:171-3. 


\title{
CHAPTER 4
}

\author{
SECTION II
}

\section{EFFECT OF CHRONOLOGICAL AGE AND TIME AFTER MENOPAUSE ON OVARIAN VEIN LEVELS OF TESTOSTERONE AND ANDROSTENEDIONE IN POSTMENOPAUSAL WOMEN}

\begin{abstract}
Alexander V. Sluijmer ${ }^{1,2}$, Maas Jan Heineman ${ }^{2,3}$, Frank H. de Jong ${ }^{4}$, and Johannes L.H. Evers'.
\end{abstract}

Department of Obstetrics and Gynaecology, Wilhelmina Ziekenhuis, Assen'; Department of Obstetrics and Gynaecology, Ziekenhuis De Wever en Gregorius, Heerlen²; Department of Obstetrics and Gynaecology, Academisch Ziekenhuis, Groningen ${ }^{3}$; Department of Endocrinology and Reproduction, Erasmus Universiteit, Rotterdam*; Department of Obstetrics and Gynaecology, Academisch Ziekenhuis, Maastricht, The Netherlands ${ }^{5}$ 


\section{Abstract}

In 20 postmenopausal women the effects of chronological age and time after menopause (postmenopausal age) on ovarian vein androgen levels were studied.

During oophorectomy, ovarian vein hormone levels of testosterone $(\mathrm{T})$ and androstenedione (A) were measured.

The median for chronological age was 60 years and for postmenopausal age 10 years. For both chronological age and postmenopausal age, no significant relation with ovarian vein levels of $\mathrm{A}$ and $\mathrm{T}$ were found.

We were not able to demonstrate a relation between pelvic $\mathrm{A}$ and $\mathrm{T}$ levels with either chronological or postmenopausal age.

\section{Introduction}

Many studies have been published regarding the endocrine function of the postmenopausal ovary (1-6). Recently we studied the effect of pituitary down-regulation and oophorectomy on the endocrine activity of the postmenopausal ovary in a group of 35 postmenopausal women (7). From this study we concluded that the postmenopausal ovary produces significant amounts of $\mathrm{A}$ and $\mathrm{T}$, although only $\mathrm{T}$ contributes significantly to its peripheral serum levels.

Little is known about the influence of ageing after the menopause on the endocrine function of the postmenopausal ovary. In the studies at present available, serum hormone levels were only measured in peripheral vein blood. From a previous study we know that to determine the hormone secretion of an ovary, it is important to measure serum hormone levels in ovarian vein blood (8).

The aim of the present investigation was to study the relation of chronological age and postmenopausal age with the ovarian vein blood levels of $\mathrm{A}$ and $\mathrm{T}$.

\section{Patients and methods}

Twenty postmenopausal women, who underwent laparotomy for various gynecologic disorders, were investigated. All women had their last menstrual period more than twelve months prior to operation. None of the patients had received estrogen replacement therapy for at least six months preceding the investigation. The clinical data are summerized in Table 1. The study was approved by the hospital ethics committee. All patients gave a written informed consent.

During oophorectomy, from all patients ovarian vein blood was obtained according to a method described previously (8). Bloodsamples were allowed to clot after collection. The collected serum was stored at $-20^{\circ} \mathrm{C}$ until hormone estimations.

Serum levels of androstenedione (A) and testosterone (T), were measured as described previously $([9,10])$ Diagnostic Products Corp. Los Angeles,CA). The sensi- 
tivities of the assays were: $\mathrm{A}, 0.1 \mathrm{nmol} / \mathrm{L} ; \mathrm{T}, 0.2 \mathrm{nmol} / \mathrm{L}$.

Intra- and interassay coefficients of variation were both less than $11 \%$ and $17 \%$ respectively for the A assay, and less than $3 \%$ and $5 \%$ respectively for the $\mathrm{T}$ assay.

The effect of chronological and postmenopausal age on serum hormone levels was studied by dividing the patients into two groups with the median as dividing point.

The Mann-Whitney $U$ test was used to evaluate the influence of chronological and postmenopausal age on the peripheral and ovarian vein serum hormone levels in both groups.

Table 1. Clinical data of 20 postmenopausal women undergoing uni- or bilateral salpingooophorectomy with or without hysterectomy.

Age (years)

$\begin{array}{ll}\text { mean } & : 62.9(52-81) \\ \text { median } & : 60.0\end{array}$

Years since menopause

mean $\quad: 12.5(1-32)$

median $: 10.0$

Indication for surgery:

$\begin{array}{llr}\text { Endometrial carcinoma } & : & 13 \\ \text { Endometrial atypia } & : & 3 \\ \text { Leiomyoma } & : & 2 \\ \text { Benign ovarian cysts } & : & 1 \\ \text { Miscellaneous } & : & 1\end{array}$

\section{Results}

For chronological age the median was 60.0 years and for postmenopausal age 10.0 years. No significant differences were noted between the left and right ovarian vein levels of all hormones studied. Therefore, the mean of these two concentrations for each patient was used for further calculations. If only one ovarian vein was sampled, the value for this sample was used. The effects of chronological and postmenopausal age on the serum hormone levels in peripheral and ovarian vein blood have been described in Table 2 and 3.

For both chronological age and postmenopausal age, no significant differences were found for serum levels of $\mathrm{A}$ and $\mathrm{T}$. 
Table 2. Ovarian vein serum hormone levels of $A(n m o l / L)$ and $T(n m o l / L)$ in postmenopausal women $\leq 60$ years $(n=10)$ and $>60$ years $(n=10)$ old.

A

$\leq 60$ years

range

median

$>60$ years

range

$3.79-19.36$

11.34

$7.00-31.15$

15.88
$\mathrm{T}$

$1.7-6.2$

2.9

$1.3-41.1$

4.2

Mann-Whitney U test: no significant differences were found.

Table 3. Ovarian vein serum hormone levels of $A(n m o l / L)$ and $T(n m o l / L)$ in postmenopausal women $\leq 10$ years $(n=10)$ and $>10$ years $(n=10)$ after menopause.

A

$\leq 10$ years

range

median

$>10$ years

range

median
$3.79-19.36$

11.54

7.00-31.15

15.88
$\mathrm{T}$

$1.7-6.2$

2.9

$1.3-41.1$

4.2

Mann-Whitney U test: no significant differences were found.

\section{Discussion}

We studied the effect of chronological age and postmenopausal age on the ovarian vein serum levels of $\mathrm{A}$ and $\mathrm{T}$, because in a previous study of 35 postmenopausal women, it was found that the postmenopausal ovary produces significant amounts of A and T (7). 
Till now, only a few studies have been published on the relation between chronological age and postmenopausal age on circulating steroids levels and their regulation mechanisms in postmenopausal women. In these studies, only peripheral vein serum levels of A and $\mathrm{T}$ were measured. It is known, however, that measuring hormone serum levels in the ovarian vein is the most accurate way to determine the secretion of ovarian hormones.

Kwekkeboom and coworkers showed in 680 normal postmenopausal women that serum levels of LH and FSH decreased with age (9). They suggested a direct effect of ageing on gonadotroph cells or an effect of age on the hypothalamic regulation of these cells. Rossmanith and coworkers suggested that the mechanism accounting for the reduction in pituitary gonadotrophin release is the reduced release of hypothalamic GnRH and of changes in the pituitary gonadotroph responsiveness $(11,12)$. Other studies, however, found no effect of postmenopausal age on the basal activity of the hypothalamus and/or the pituitary concerning gonadotrophin production and release $(13,14)$. Alexander and coworkers found no age related effect on hypothalamic GnRH secretory function and release of pituitary gonadotrophins, but a primary age-related change in the ovary (15).

For E1 and E2 it was found that chronological age or postmenopausal age had no significant influence on the serum levels (2,16-19). Chakravarti and coworkers (17) showed that in the late postmenopausal women the serum levels of E2 had a tendency to increase, whereas Vermeulen and coworkers (18) noted the opposite. Badawy and coworkers, found a highly significant inverse correlation between postmenopausal age and E1 and E2 serum levels (20).

A positive relationship between SHBG and age has been described $(2,21)$. Others, however, found no relationship between SHBG with age in postmenopausal women although the group of patients studied was smaller (22).

Meldrum et al. found a significant decline for DHEAS in older postmenopausal women (19).

Chakravarti et al. found in the late postmenopausal women a lower concentration of $\mathrm{A}$ and a higher concentration for $\mathrm{T}$ compared with premenopausal levels (17). No relevant differences for $\mathrm{A}$ and $\mathrm{T}$ were noted in the study of the effect of ageing on circulating steroid levels of Meldrum et al. (19).

In our study no relevant differences for $\mathrm{A}$ and $\mathrm{T}$ with chronological age and postmenopausal age were noted. Therefore, we conclude that chronological age and postmenopausal age has no clear effect on the production of $\mathrm{A}$ and $\mathrm{T}$ by the postmenopausal ovary. We realize, however, that the present study has some limitations. The number of patients $(\mathrm{n}=20)$ studied is small and the age range $(52-81 \mathrm{yrs})$ is large. The endocrine parameters ( $A$ and $T$ ) demonstrate a wide range as well. In order to study the relation between chronological age and postmenopausal age with ovarian steroid production a much larger study group is required and probably more specific endocrine parameters (local steroid production) should be determined. 


\section{References}

1. Mattingly RF, Huang WY. Steroidogenesis of the menopausal and postmenopausal ovary. Am J Obstet Gynecol 1969;103: 679-93.

2. Judd HL, Judd GE, Lucas WE, Yen SSC. Endocrine function of the postmenopausal ovary: concentration of androgens and estrogens in ovarian and peripheral vein blood. J Clin Endocrinol Metab 1974;39:1020-4.

3. Vermeulen A. The hormonal activity of the postmenopausal ovary. J Clin Endocrinol Metab $1976 ; 42: 247-53$.

4. Greenblatt RB, Colle ML, Mahesh VB. Ovarian and adrenal steroid production in the postmenopausal woman. Obstet Gynecol 1976;47:383-7.

5. Longcope C, Hunter R, Franz C. Steroid secretion by the postmenopausal ovary. Am J Obstet Gynecol 1980;138:564-8.

6. Lucisano A, Acampora MG, Russo N, Maniccia E, Montemurro A, Dell'Acqua S. Ovarian and peripheral plasma levels of progestogens, androgens and oestrogens in postmenopausal women. Maturitas 1984;6:45-53.

7. Sluijmer AV, Heineman MJ, de Jong FH, Evers JLH. Endocrine activity of the postmenopausal ovary: the effects of pituitary down-regulation and oophorectomy. J Clin Endocrinol Metab 1995;80:2163-7.

8. Heineman MJ, Sluijmer AV, Evers JLH. Utero-ovarian vein blood sampling in postmenopausal women. Fertil Steril 1993;60:184-6.

9. Kwekkeboom DJ, de Jong FH, van Hemert AM, Vandenbroucke JP, Valkenburg HA, Lamberts SWJ. Serum gonadotropins and $\alpha$-subunit decline in aging normal postmenopausal women. J Clin Endocrinol Metab 1990;70:944-50.

10. Verjans HL, Cooke BA, de Jong FH, de Jong CMM, van der Molen HJ. Evaluation of a radioimmunoassay for testosterone estimation. J Steroid Biochem 1973;4:665-76.

11. Rossmanith WG, Scherbaum WA, Lauritzen C. Gonadotropin secretion during aging in postmenopausal women. Neuroendocrinol 1991;54:211-8.

12. Rossmanith WG, Reichelt C, Scherbaum WA. Neuroendocrinology of aging in humans: attenuated sensitivity to sex steroid feedback in elderly postmenopausal women. Neuroendocrinol 1994;59:35562.

13. Scaglia H, Medina M, Pinto-Ferreira AL, Vázques G, Gual C, Pérez-Palacios G. Pituitary LH and FSH secretion and responsiveness in women of old age. Acta Endocrinol 1976; 81:673-9.

14. Sluijmer AV, Heineman MJ, De Leeuw R, Evers JLH. Pituitary down-regulation with a single depot-dose of a GnRH agonist (Triptorelin) in postmenopausal women. Maturitas 1994;20:45-51.

15. Alexander SE, Aksel S, Hazelton JM, Yeoman RR, Gilmore SM. The effect of aging on hypothalamic function in oophorectomized women. Am J Obstet Gynecol 1990;162:446-9. 
16. Judd HL, Lucas WE, Yen SSC. Serum 17B-estradiol and estrone levels in postmenopausal women with and without endometrial cancer. J Clin Endocrinol Metab 1976;43:272-8.

17. Chakravarti S, Collins WP, Forecast JD, Newton JR, Oram DH, Studd JWW. Hormonal profiles after the menopause. Br Med J 1976;2:784-7.

18. Vermeulen A, Verdonck L. Sex hormone concentrations in postmenopausal women: relation to obesity, fat mass, age and years postmenopause. Clin Endocrinol 1978;9:59-66.

19. Meldrum DR, Davidson BJ, Tataryn IV, Judd HL. Changes in circulating steroids with aging in postmenopausal women. Obstet Gynecol 1981;57:624-8.

20. Badawy SZA, Elliott LJ, Elbadawi A. Plasma levels of oestrone and oestradiol-17B in postmenopausal women. Br J Obstet Gynaecol 1979;86:56-63.

21. Maruyama Y, Aoki N, Suzuki Y, Sinohara H, Yamamoto T. Variation with age in the levels of sexsteroid-binding plasma protein as determined by radioimmunoassay. Acta Endocrinol 1984;106:42832.

22. Bolufer P, Antonio P, Garcia R, Munoz J, Rodriguez A, Romeu A. Role of the ovary in the regulation of sex hormone binding globulin and its contribution to peripheral levels of androstenedione. Exp Clin Endocrinol 1983;82:29-34. 


\title{
CHAPTER 5
}

\section{RELATIONSHIP BETWEEN OVARIAN PRODUCTION OF ESTRONE, ESTRADIOL, TESTOSTERONE, AND ANDROSTENEDIONE AND THE OVARIAN DEGREE OF STROMAL HYPERPLASIA IN POSTMENOPAUSAL WOMEN}

\author{
A.V. Sluijmer, $\mathrm{MD}^{1,2}$, M.J. Heineman, $\mathrm{MD}, \mathrm{PhD}^{2,3}$, \\ Joh. Koudstaal, $\mathrm{MD}, \mathrm{PhD}^{4}$, P.H.M.H. Theunissen, $\mathrm{MD}, \mathrm{PhD}^{4}$, \\ F.H. de Jong, $\mathrm{PhD}^{5}$, and J.L.H. Evers, $\mathrm{MD}, \mathrm{PhD}^{6}$
}

From the 'Department of Obstetrics and Gynecology, Wilhelmina Ziekenhuis, Assen, ${ }^{2}$ Department of Obstetrics and Gynecology and ${ }^{4}$ Department of Pathology, Ziekenhuis

De Wever en Gregorius, Heerlen, ${ }^{3}$ Department of Obstetrics and Gynecology,

Academisch Ziekenhuis, Groningen, ${ }^{5}$ Department of Endocrinology and Reproduction, Erasmus Universiteit, Rotterdam, and ${ }^{6}$ Department of Obstetrics and Gynecology, Academisch Ziekenhuis, Maastricht, The Netherlands. 


\section{Abstract}

Objective: To study the relationship between ovarian production of estrone (E1), estradiol (E2), testosterone (T), and androstenedione (A) and the ovarian degree of stromal hyperplasia in postmenopausal women.

Design: In 18 postmenopausal women, the ovarian vein hormone levels of E1, $\mathrm{E} 2$, $\mathrm{T}$, and $\mathrm{A}$ were compared with the degree of ovarian stromal hyperplasia. The degree of stromal hyperplasia was assessed by histological analysis (group 1: atrophic ovaries, $\mathrm{n}=8$; group 2: slight stromal hyperplasia, $\mathrm{n}=8$; group 3 : moderate or severe stromal hyperplasia, $\mathrm{n}=2$ ).

Results: The ovarian levels of E1 and E2 did not correlate with the ovarian degree of stromal hyperplasia. The ovarian levels of $\mathrm{A}$ in group 3 were significantly higher than those in groups 1 and $2(\mathrm{P}<0.02$ and $\mathrm{P}<0.01$, respectively). The ovarian levels of $\mathrm{T}$ in group 3 were significantly higher than those in group $1(\mathrm{P}<0.01)$ but did not differ significantly from those in group 2 .

Conclusions: The amount of stromal hyperplasia in postmenopausal ovaries is correlated with the ovarian vein levels of A and T. Morphological characteristics of the postmenopausal ovary determine the local (pelvic) endocrine status and may play a role in the etiology of hormone-dependent diseases of the internal genitals.

\section{Introduction}

The ovary is an organ that exhibits considerable morphological and functional changes from the embryonic stage in life until the postmenopausal period. Much is known about these changes, especially in the reproductive period of life. Less is known about the postmenopausal state of the ovary. In a previous study, we concluded that the postmenopausal ovary only produces significant amounts of androstenedione (A) and testosterone (T) and is still partly under pituitary control (1). In the present study, we investigated the relationship between the morphological state of the postmenopausal ovary and the endocrine function, with special emphasis on the production of A and T.

\section{Patients and methods}

Eighteen postmenopausal women (all participants in a previous study [1]), who underwent laparotomy for different gynecological disorders were included in the study. The clinical data are summarized in Table 1. All women had their last menstrual period more than 12 months before surgery; none had received estrogen replacement therapy for at least 6 months before the investigation. The study was approved by the Hospital Ethics Committee. All patients gave written informed consent. 
Table 1. Clinical data of 18 postmenopausal women undergoing oophorectomy with or without hysterectomy.

Age (year)

Years since menopause

Weight $(\mathrm{kg})$

Height (m)

Body mass index $\left(\mathrm{kg} / \mathrm{m}^{2}\right)$

Indication for surgery

Endometrial carcinoma

Endometrial atypia

Cervical atypia

Uterine leiomyoma

Benign ovarian cyst
$63.1(52-81)$

$12.4 \quad(1-32)$

$72.7(52.0-107.5)$

$1.59 \quad(1.47-1.70)$

$28.8(20.1-42.5)$

Numerical data are shown as medians, with the range in parentheses.

At the time of surgery, blood was taken from the ovarian veins according to a method described previously (2). Blood samples were allowed to clot after collection. The collected serum was stored at $-20^{\circ} \mathrm{C}$ until assayed. Serum levels of estrone (E1) and $T$ were measured by radio-immunoassay (RIA), as described previously $(3,4)$. Estradiol (E2) and A were measured with RIA kits (Diagnostic Products Corp., Los Angeles, CA). The sensitivities of the assays were $20 \mathrm{pmol} / \mathrm{L}$ (E1), $4 \mathrm{pmol} / \mathrm{L}$ (E2), $0.2 \mathrm{nmol} / \mathrm{L}$ (T), and $0.1 \mathrm{nmol} / \mathrm{L}(\mathrm{A})$.

Intra- and interassay coefficients of variation were less than $14 \%$ and $19 \%$, respectively, for the E1 assay; less than $15 \%$ and $19 \%$ for the E2 assay, respectively; less than $3 \%$ and $5 \%$, for the $\mathrm{T}$ assay, respectively; and less than $11 \%$ and $17 \%$ for the $\mathrm{A}$ assay, respectively.

After removal, the ovaries of the 18 postmenopausal women were fixated in buffered formaline, and transverse sections of the whole ovaries were made. A representative section of each ovary was classified after staining with hematoxylin and eosin into one of three groups according to the degree of stromal hyperplasia: an atrophic ovary is defined as an ovary with a maximum ovarian cortex width of $1 \mathrm{~mm}$ (Fig. 1), slight stromal hyperplasia is defined as an ovary with a cortex wider than $1 \mathrm{~mm}$ (Fig. 2), and moderate or severe stromal hyperplasia is defined as an ovary with a cortex wider than $1 \mathrm{~mm}$ with cellular cortical stroma present in the medulla (Fig. 3). Three investigators (M.J.H., J.K., P.H.M.H.T.) classified the ovaries independently, all unaware of the endocrine data from any one patient. In 13 patients, the 3 individual scores were identical. In 5 patients, consensus was attained on histological arguments.

For statistical analysis one-way analysis of variance was used. 


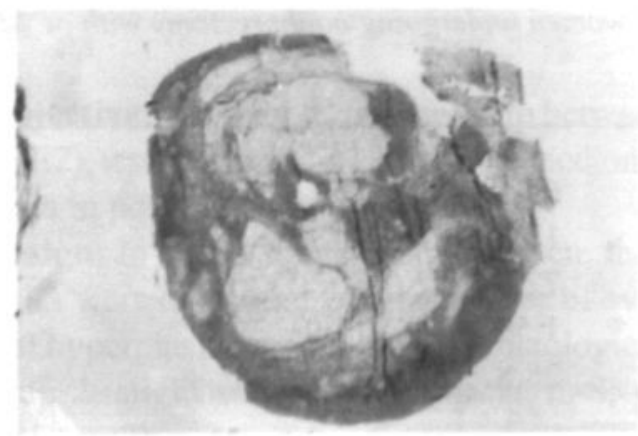

Fig. 1. Atrophic ovary.

The ovarian cortex is not wider than $1 \mathrm{~mm}$.

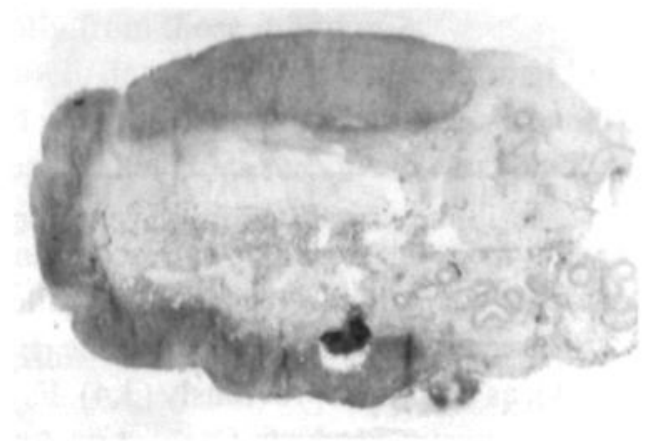

Fig. 2. Ovary with slight stromal hyperplasia.

The ovarian cortex is wider than $1 \mathrm{~mm}$.

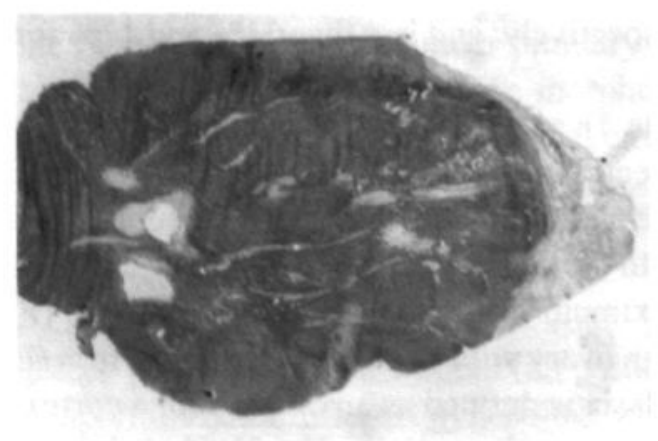

Fig. 3. Ovary with moderate or marked stromal hyperplasia.

The ovarian cortex is wider than Imm, and cellular cortical stroma is present in the medulla. 
Table 2. Ovarian vein levels of estrone (E1) and estradiol (E2) in 18 postmenopausal women with ovaries classified acconding to the degree of stromal hyperplasia.

Atrophic $\begin{gathered}\text { Slight stromal } \\ \text { hyperplasia }\end{gathered} \quad \begin{gathered}\text { Moderate-severe } \\ \text { hyperplasia }\end{gathered}$

$\mathrm{n}$

8

8

2

E1 $(\mathrm{pmol} / \mathrm{L})$

$\begin{array}{lccc}\text { Mean }( \pm \text { SEM }) & 184 \pm 79 & 168 \pm 76 & 300 \pm 49 \\ \text { Median } & 206 & 166 & 300 \\ \text { Range } & 44-258 & 64-285 & 265-334\end{array}$

E2 $(\mathrm{pmol} / \mathrm{L})$

$\begin{array}{lccc}\text { Mean }( \pm \text { SEM }) & 81 \pm 36 & 115 \pm 127 & 120 \pm 16 \\ \text { Median } & 88 & 76 & 120 \\ \text { Range } & 11-126 & 30-419 & 109-131\end{array}$

One-way analysis of variance: no significant differences were found between EI and E2 and the ovarian degree of stromal hyperplasia.

\section{Results}

No significant differences were noted between the left and right ovarian vein levels of E1, E2, A, and T. Therefore, the mean of these two concentrations for each patient was used for further calculations. If only one ovarian vein was sampled, the value for this sample was used.

The number of patients in each group and the mean, median, and range of ovarian vein serum hormone levels of E1, E2, T, and A have been summarized in Tables 2 and 3.

The ovarian vein levels of E1 and E2 were not correlated with the ovarian degree of stromal hyperplasia. The ovarian vein level of $\mathrm{T}$ in group 3 was significantly higher than that in group $1(\mathrm{P}<0.01)$ but did not differ significantly from the level of $\mathrm{T}$ in group 2. The ovarian vein level of $A$ was significantly higher in group 3 than in groups 1 and 2 $(\mathrm{P}<0.02$ and $\mathrm{P}<0.01$, respectively). 
Table 3. Ovarian vein levels of testosterone (T) and androstenedione $(A)$ in 18 postmenopausal women with ovaries classified according to the degree of stromal hyperplasia.

Atrophic $\begin{gathered}\text { Slight stromal } \\ \text { hyperplasia }\end{gathered} \quad \begin{gathered}\text { Moderate-severe } \\ \text { hyperplasia }\end{gathered}$

$\mathrm{n}$

$\mathrm{T}(\mathrm{nmol} / \mathrm{L})$

Median

Range
$3.0 \pm 1.1$

$2.9^{a}$

$1.3-4.4$
$8.2 \pm 13.4$

3.2

$1.7-41.1$
$9.1 \pm 3.5$

9.1

$6.6-11.5$

A $(\mathrm{nmol} / \mathrm{L})$

$\begin{array}{lc}\text { Mean }( \pm \text { SEM) } & 12.7 \pm 5.6 \\ \text { Median } & 11.6^{\mathrm{b}} \\ \text { Range } & 3.8-22.4\end{array}$

$11.2 \pm 4.7$

$10.8^{\mathrm{c}}$

$4.8-19.4$
$27.4 \pm 5.3$

$27.4^{b, c}$

$23.7-31.2$

One-way analysis of variance: a significant difference was found between the ovarian vein levels for $T$ in groups 1 and $3(a: P<0.01)$. The ovarian vein levels of $A$ in group 3 were significantly higher than those in group 1 (b: $P<0.02)$ and in group 2 (c: $P<0.01)$.

\section{Discussion}

The ovary is a dynamic organ in which the process of aging takes place in an orderly and progressive way. During the reproductive period, the size and weight of the ovaries vary considerably, depending predominantly on the follicular content. With time, there is a gradual loss of ova and a progressive thinning of the ovarian cortex that becomes increasingly wrinkled and gyrated. Small white scars (corpora albicantia) are typically present in the thickened cortex. The vessels of the hilum and medulla become progressively sclerosed (5). All these changes result in a decrease in ovarian size after menopause.

The size of the postmenopausal ovaries differs widely (6), caused in part by the ovarian stromal cells. At one extreme, there is stromal atrophy. At the other extreme, there is marked stromal proliferation appearing as stromal hyperplasia (7).

More than 50 years ago, the relation between ovarian stromal activity (e.g., hyperplasia) and endometrial cancer was first indicated by Smith (8) and this relationship was established subsequently for breast cancer (9). Hertig stated that endometrial activity is correlated with the activity in the ovarian cortex (10). Woll et al. were the first to suggest that steroids are produced by cells localized in the ovarian stroma (11). Many endocrinological studies of postmenopausal ovarian function followed, but the findings 
were conflicting (12-18). Dowsett et al. found that the ovarian production of steroids could be suppressed by the administration of a gonadotropin-releasing hormone agonist (19).

Although stromal activity of the postmenopausal ovary varies and this variation is assumed to correlate with its endocrine function, few studies have been performed to corroborate this assumption.

It is now generally accepted that the postmenopausal ovary produces steroids, mainly androgens in the form of $\mathrm{T}$ and $\mathrm{A}(20)$. This finding was confirmed by a previous study on the endocrine activity of the postmenopausal ovary in 35 patients (1). In the present study, we investigated the relationship between the morphological state of the postmenopausal ovary and its endocrine function. We could not demonstrate a relation between ovarian vein levels of E1 and E2 and the degree of stromal hyperplasia of the ovaries. This finding stresses that a direct relationship between ovarian morphology, local estrogen levels, and endometrial pathology is lacking. From our data it cannot be concluded that estrogens play a role in the presence of (pre)malignant changes of the endometrium. Interestingly, we were able to demonstrate a significant relationship between the degree of stromal hyperplasia and the production of androgens (both A and $\mathrm{T})$. Therefore, it is tempting to speculate that ovarian morphology and consequently ovarian androgen production play a role in the development of pathological conditions of the uterine endometrium. We reported previously that ovarian vein concentrations of $\mathrm{A}$ and $\mathrm{T}$ were elevated in women with endometrial cancer when compared with the levels determined in women with benign gynecological conditions (21).

The findings of the present study are not completely in accordance with the results reported by Lucisano et al. (22) who found that the ovarian steroid levels of E1, E2, and A, but not $T$, were significantly increased in ovarian venous blood of patients with moderate or marked stromal hyperplasia as compared with the levels in the ovarian vein of women with ovaries with stromal atrophy (20). The discrepancy with our findings is difficult to explain. The selection of patients may have played a role. In our study, 15 of 18 patients had endometrial atypic hyperplasia or endometrial carcinoma. In the study by Lucisano et al., 35 of 58 postmenopausal women had endometrial pathology. Although it is tempting to speculate on a causal relationship between ovarian stromal hyperplasia, elevated androgen concentrations, and endometrial pathology, one has to face the possibility that elevated concentrations of androgens in the ovarian venous blood is a phenomenon primarily associated with the presence of endometrial carcinoma. Further studies into this field are warranted.

The small numbers of women in the individual study groups do not allow conclusions on the relation between time since menopause and ovarian morphology or on the relation between the different steroids determined. From the present study, we conclude that the amount of stromal hyperplasia in postmenopausal ovaries is correlated with the ovarian vein levels of $\mathrm{A}$ and $\mathrm{T}$. 


\section{References}

1. Sluijmer AV, Heineman MJ, de Jong FH, Evers JLH. Endocrine activity of the postmenopausal ovary: the effects of pituitary down-regulation and oophorectomy. J Clin Endocrinol Metab 1995;80:2163-7.

2. Heineman MJ, Sluijmer AV, Evers JLH. Utero-ovarian vein blood sampling in postmenopausal women. Fertil Steril 1993;60:184-6.

3. Kwekkeboom DJ, de Jong FH, van Hemert AM, Vandenbroucke JP, Valkenburg HA, Lamberts SWJ. Serum gonadotropins and $\alpha$-subunit decline in aging normal postmenopausal women. J Clin Endocrinol Metab 1990;70:944-50.

4. Verjans HL, Cooke BA, de Jong FH, de Jong CMM, van der Molen HJ. Evaluation of a radioimmunoassay for testosterone estimation. J Steroid Biochem 1973;4:665-76.

5. Clement PB. Histology of the ovary. Am J Surg Pathol 1987;11:277-303.

6. Goswamy RK, Campbell S, Royston JP, Bhan V, Battersby RH, Hall VJ, Whitehead MI, Collins WP. Ovarian size in postmenopausal women. Br J Obstet Gynaecol 1988;95:795-801.

7. Boss JH, Scully RE, Wegner KH, Cohen RB. Structural variations in the adult ovary: clinical significance. Obstet Gynecol 1965;25:747-64.

8. Smith GVS. Carcinoma of the endometrium: a review with results of treatment through 1935. N Engl J Med 1941;225:608-15.

9. Sommers SC, Teloh HA. Ovarian stromal hyperplasia in breast cancer. Arch Pathol 1952;53:160-6.

10. Hertig AT. The aging ovary: a preliminary note. J Clin Endocrinol 1944;4:581-2.

11. Woll E, Hertig AT, Smith GVS, Johnson LC. The ovary in endometrial carcinoma: with notes on the morphological history of the aging ovary. Am J Obstet Gynecol 1948;56:617-33.

12. Mattingly RF, Huang WY. Steroidogenesis of the menopausal and postmenopausal ovary. Am J Obstet Gynecol 1969;103:679-93.

13. Judd HL, Judd GE, Lucas WE, Yen SSC. Endocrine function of the postmenopausal ovary: concentration of androgens and estrogens in ovarian and peripheral vein blood. J Clin Endocrinol Metab 1974;39:1020-4.

14. Vermeulen A. The hormonal activity of the postmenopausal ovary. J Clin Endocrinol Metab 1976;42:247-53.

15. Judd HL, Lucas WE, Yen SSC. Serum 17ß-estradiol and estrone levels in postmenopausal women with and without endometrial cancer. J Clin Endocrinol Metab 1976;43:272-8.

16. Greenblatt RB, Colle ML, Mahesh VB. Ovarian and adrenal steroid production in the postmenopausal woman. Obstet Gynecol 1976;47:383-7.

17. Longeope C, Hunter R, Franz C. Steroid secretion by the postmenopausal ovary. Am J Obstet Gynecol 1980;138:564-8. 
18. Nagamani M, Hannigan EV, Dillard EA, van Dinh T. Ovarian steroid secretion in postmenopausal women with and without endometrial cancer. J Clin Endocrinol Metab 1986;62: 508-12.

19. Dowsett M, Cantwell B, Lal A, Jeffcoate SL, Harris AL. Suppression of postmenopausal ovarian steroidogenesis with the luteinizing hormone-releasing hormone agonist goserelin. J Clin Endocrinol Metab 1988;66:672-7.

20. Adashi EY. The climacteric ovary as a functional gonadotropin-driven androgen-producing gland. Fertil Steril 1994;62:20-7.

21. Heineman MJ, Sluijmer AV, Kampschöer PHNM, de Jong FH, Evers JLH. Utero-ovarian vein blood sampling in postmenopausal women with and without endometrial cancer. Fertil Steril 1995;Suppl:S92(Abstract O-187).

22. Lucisano A, Russo N, Acampora MG, Fabiano A, Fattibene M, Parlati E, Maniccia E, Dell'Acqua $\mathrm{S}$. Ovarian and peripheral androgen and oestrogen levels in postmenopausal women: correlations with ovarian histology. Maturitas 1986;8:57-65. 


\section{CHAPTER 6}

\section{A STUDY OF THE PRESENCE AND EXPRESSION OF LH, FSH AND GnRH RECEPTORS IN HUMAN POSTMENOPAUSAL OVARIES}

Sluijmer $\mathrm{AV}^{1,2}$, Heineman $\mathrm{MJ}^{2,3}$, de Jong $\mathrm{FH}^{4}$, Themmen $\mathrm{APN}^{4}$, van der Kar SAT ${ }^{5}$, Grootenhuis $\mathrm{AJ}^{5}$, and Evers $\mathrm{JLH}^{6}$

Department of Obstetrics and Gynaecology, Wilhelmina Ziekenhuis, Assen' ; Department of Obstetrics and Gynaecology, Ziekenhuis De Wever en Gregorius, Heerlen $^{2}$; Department of Obstetrics and Gynaecology, Academisch Ziekenhuis, Groningen $^{3}$; Department of Endocrinology and Reproduction, Erasmus Universiteit, Rotterdam ${ }^{4}$; Scientific Development Group, Organon International B.V., Oss ${ }^{5}$; Department of Obstetrics and Gynaecology, Academisch Ziekenhuis, Maastricht, The Netherlands ${ }^{6}$ 


\section{Abstract}

The presence of luteinizing hormone $(\mathrm{LH})$ receptors, follicle-stimulating hormone (FSH) receptors, and gonadotrophin-releasing hormone $(\mathrm{GnRH})$ receptors was studied in human postmenopausal ovaries. In ovaries of 10 postmenopausal women, no FSH and $\mathrm{LH}$ receptors were detected by autoradiography after incubation of tissue slices with ${ }^{125} \mathrm{I}$-labeled hormones. By analysis of $\mathrm{FSH}, \mathrm{LH}$ and $\mathrm{GnRH}$ receptor mRNAs in ovaries of 7 postmenopausal women with endometrial carcinoma, expression of full length FSH and GnRH receptor mRNA was found using RNase protection. Expression of full length LH receptor mRNA was absent, whereas expression of LH receptor mRNA splice variants 1,2 and 3 was found. We hypothesize that $\mathrm{GnRH}$ and $\mathrm{GnRH}$ agonists not only have an indirect effect on postmenopausal ovarian function (via suppression of LH and $\mathrm{FSH}$ ) but also may have a direct effect on postmenopausal ovarian hormone production.

\section{Introduction}

The gonadotrophins LH and FSH are produced by the pituitary and are the main regulators of gonadal function. The production of $\mathrm{LH}$ and $\mathrm{FSH}$ is under control of the central nervous system through the secretion of $\mathrm{GnRH}$ from the hypothalamus into the hypothalamo-pituitary portal blood, and of feedback action of gonadal hormones.

LH and FSH act on specific cells in the ovaries. LH stimulates theca and granulosa cells, whereas FSH stimulates granulosa cells.

Gonadotrophic hormone action is mediated via specific membrane-associated hormone receptors. These gonadotrophin receptors belong to the family of $\mathrm{G}$ proteincoupled receptors, which interact with intracellular guanidine nucleotide-binding proteins or $\mathrm{G}$ proteins (1-3). G protein-coupled receptors show general characteristics such as ligand binding, receptor activation, G protein coupling, intracellular signalling and cellular desensitization.

There are various ways of detecting the presence of receptors. The LH-receptor has been detected with specific monoclonal antibodies reacting with the extracellular domain of the LH receptor (4), or by the detection of LH bound to the receptor using monoclonal antibodies recognising the B-subunit of LH (5). With the autoradiographic method using ${ }^{125} \mathrm{I}-\mathrm{FSH},{ }^{125} \mathrm{I}$-hCG or other LH-like proteins, it is possible to localise FSH and $\mathrm{LH}$ receptors in the ovary (6). The detection of mRNAs encoding for the receptors of LH, FSH and GnRH can be performed by Northern blot analysis or RNase protection.

The purpose of the present study was to examine the presence of LH and FSH receptors on different cell types in intact postmenopausal ovaries by the autoradiographic method using ${ }^{125} \mathrm{I}-\mathrm{FSH}$ or ${ }^{125} \mathrm{I}-\mathrm{hCG}$. The expression of LH, FSH and $\mathrm{GnRH}$ receptor mRNAs was determined in homogenized postmenopausal ovaries. 


\section{Material and methods}

\section{Autoradiographic method}

In ovaries from ten postmenopausal patients the presence of LH and FSH receptors was studied by the autoradiographic method using ${ }^{125} \mathrm{I}-\mathrm{FSH}$, or ${ }^{125} \mathrm{I}-\mathrm{hCG}$. Women were considered postmenopausal if their last menstrual period had been more than twelve months before the onset of the study. None of the patients had received oestrogen replacement therapy for at least six months preceding the investigation. The protocol used for this study was approved by the hospital ethics committee. All patients signed an informed consent. The patients underwent uni- or bilateral salpingo-oophorectomy for various reasons.

The ovarian specimens were frozen immediately in liquid nitrogen and stored at $-80^{\circ} \mathrm{C}$. Sections of $15 \mu \mathrm{m}$ were sliced at $-29^{\circ} \mathrm{C}$, using a cryostat microtome and were collected on gelatin coated object slides kept at $25^{\circ} \mathrm{C}$. Object slides were kept at $-80^{\circ} \mathrm{C}$ until used. Every other section (collected on different object slides) was blown dry, fixed for 2 minutes in acetone and stained with Haematoxylin Eosin (HE). To identify cellular binding sites for hCG and FSH, sections were encircled with a hydrofobic wax (Dakopen, ITK Diagnostics BV, Uithoorn, The Netherlands), washed briefly with buffer $\mathrm{C}(10 \mathrm{mM}$ Tris, $5 \mathrm{mM} \mathrm{MgCl}, 0.1 \%(\mathrm{w} / \mathrm{vv}) \mathrm{BSA}$ at a $\mathrm{pH}$ of 7.4$)$ and incubated in a humidified chamber at room temperature for 5 hours with $10 \mu \mathrm{l}$ of a solution containing the labelled gonadotrophin $\left(0.05 \mathrm{nM}{ }^{125} \mathrm{I}-\mathrm{FSH}\right.$ [NEX-173, NEN Research Product, Hoofddorp, The Netherlands] or 0.05 nM ${ }^{125}$ I-hCG [NEX-106, NEN Research Product] in buffer C) without or with 1000x molar excess of recombinant human FSH (Org 32489, Organon, Oss, The Netherlands) or hCG (Pregnyl, Organon). The slides were washed twice in cold buffer $\mathrm{C}$ for 3 minutes, and 10 times in Milli Q water and completely dried. A Hyperfilm- ${ }^{3} \mathrm{H}$ (Amersham, Den Bosch, The Netherlands) was exposed for 7 days to the slides and developed.

\section{Receptor mRNA detection method}

The presence of $\mathrm{LH}, \mathrm{FSH}$ and $\mathrm{GnRH}$ receptors by measuring receptor mRNAs was performed in homogenized ovaries of seven other postmenopausal patients who underwent uni- or bilateral salpingo-oophorectomy because of endometrial carcinoma. As a control, three ovaries obtained from normal cyclic women were used.

\section{Isolation of RNA and RNase protection assay}

Total RNA was isolated using a microscale version of the method described by Chomczynski and Sacchi (7). The human FSH receptor RNA probe was generated from a 633 bp fragment cloned in pBluescript corresponding to bp 1306 to 1939 of the cDNA (8), and the human LH receptor RNA probe from a $350 \mathrm{bp}$ fragment cloned in pBluescript corresponding to the 5 'end of the human $\mathrm{LH}$ receptor cDNA (9). 
A human GnRH receptor RNA probe was generated from a 385 bp HindIII fcDNA fragment cloned in pBluescript (10). For the $\gamma$-actin RNA probe a $130 \mathrm{bp} \mathrm{cDNA}$ fragment in pGEM-4Z was used (11). RNase protection assays of $50 \mu \mathrm{g}$ total RNA were performed as described by Baarends et al. (12). $\gamma$-actin was used as a control for RNA loading. The relative amount of protected mRNA band was quantified through exposure of the gels to a phosphor screen (Molecular Dynamics, B \& L Systems, Zoetermeer, The Netherlands), followed by a calculation of the relative density of the obtained bands using a phospho-imager and Image Quant (Molecular Dynamics) as computer analysis software. The findings are shown in arbitrary units, expressed as the ratios between the bands and the corresponding $\gamma$-actin values.

\section{Results}

Autoradiographic method

Ovarian sections of ten postmenopausal women were available for the characterization of FSH and $\mathrm{LH}$ receptors. In the HE stained cryostat sections no follicles were visible. Incubation of alternate sections with ${ }^{125} \mathrm{I}-\mathrm{FSH}$ or ${ }^{125} \mathrm{I}-\mathrm{hCG}$ did not result in specific staining (1000x excess of cold $\mathrm{FSH}$ or $\mathrm{hCG}$ ). As a positive control, rat ovarian sections

$\square$ Normal ovaries
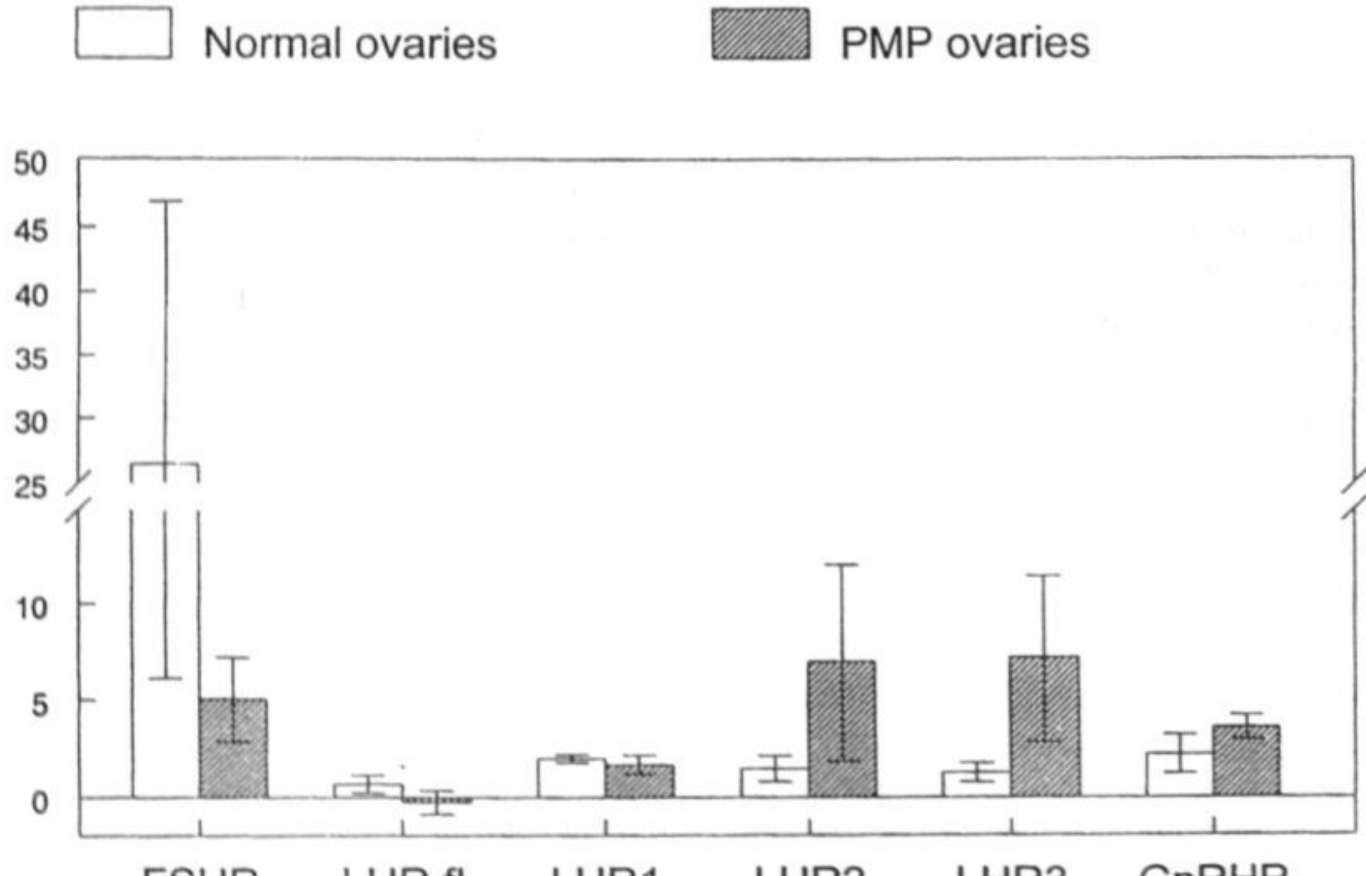

$\begin{array}{llllll}\text { FSHR } & \text { LHR fl LHR1 LHR2 LHR3 GnRHR }\end{array}$

Fig. 1: Expression of the FSH full length receptor (FSHR), the LH full length receptor (LHR fl), the LH receptor splice variants 1,2,3 (LHRI, LHR2, LHR3), and the GnRH receptor found by $R$ Nase protection experiments. 
were used resulting in clear labeling of cells of larger follicles with both FSH and hCG, and of corpora lutea with only hCG.

\section{Receptor mRNA detection method}

Results of the RNase protection experiments on control premenopausal ovaries and on a different set of seven postmenopausal ovaries are summarized in Figure 1. The mean relative expression of the full length FSH receptor in postmenopausal ovaries was five times lower than in the control ovaries. Due to the large variation in expression in the control tissues, no significant difference was found between the expression in both groups.

The full length LH receptor was just detectable in the premenopausal ovaries, but expression in the postmenopausal ovaries was at background level. In contrast, mean expression of the LH receptor splice variants 1,2, and 3, which all lack the transmembrane domain, was detected in the postmenopausal ovaries. Finally, the level of expression of the $\mathrm{GnRH}$ receptor was comparable in both groups of ovaries.

\section{Discussion}

During the reproductive stage of life, gonadotrophins control the functioning of theca, granulosa, and luteal cells of the ovary through their interaction with specific receptors. Specific receptors for $\mathrm{LH} / \mathrm{hCG}$ and FSH in these cells have been identified (13-20). Also in human ovarian neoplasms gonadotrophin binding sites for both $\mathrm{LH}$ and FSH have been localized (21). Very little information is available on gonadotrophin receptor sites in human postmenopausal ovaries.

In this study, we wanted to detect and localize LH and FSH receptors in postmenopausal ovarian tissue. For this reason we chose for the autoradiographic method using ${ }^{125} \mathrm{I}-\mathrm{FSH}$ or ${ }^{125} \mathrm{I}-\mathrm{hCG}$ as radiolabeled ligands. However, we were not able to show LH and FSH receptors in postmenopausal ovaries by this method. This was probably not caused by a lack of sensitivity of the method used because in a control group of intact rat ovaries, abundant amounts of receptors for both $\mathrm{LH}$ and FSH were localized in granulosa cells. Our results are in agreement with the results of a study by Vihko and coworkers on the presence of these receptors in human postmenopausal ovaries (22). These authors explained their results on basis of the high serum gonadotrophin levels in postmenopausal women; a negative correlation was found between serum levels of LH and FSH and ovarian LH and FSH receptors. Peluso and co-workers, however, reported that binding sites for LH and FSH were localized in the cells of cortical stroma of postmenopausal ovaries (23). This was confirmed in a study by Nakano and co-workers (24). In all of these studies the autoradiographic method was used. The reason for the varying results of these investigations remains unclear.

Another method for measuring the possible presence of $\mathrm{LH}$ and FSH receptors is detecting the presence of $\mathrm{LH}$ and FSH receptor messengerRNA (mRNA) by RNase pro- 
tection analysis. The presence of LH and FSH mRNAs has been found in studies of ovaries during the reproductive period of life, especially in the granulosa cells of preovulatory follicles (25-27). No information exists on the presence of LH and FSH receptor mRNA in human postmenopausal ovaries.

In the present study we could detect the expression of full length FSH $\mathrm{mRNa}$, but only of splice variants of LH mRNA. Since these splice variants lack essential exons, they will not be able to convey the LH signal to the inside of the cell.

The presence of GnRH receptor mRNA in human ovaries and in ovaries of cycling animals has been demonstrated before (28-32). Also in ovarian tumours expression of GnRH receptor has been found (33). The present study is the first to show expression of $\mathrm{GnRH}$ receptor mRNA in human postmenopausal ovaries.

In a previous study, we demonstrated that the postmenopausal ovary produces significant amounts of $\mathrm{A}$ and $\mathrm{T}$ (34). We suggested that the production of $\mathrm{T}$ by the postmenopausal ovary was in part stimulated by the high levels of circulating gonadotrophins, because down-regulation of serum gonadotrophin levels by administration of a GnRH agonist resulted in a decrease of $\mathrm{T}$ production by the postmenopausal ovary. Alternatively, because of the detection of GnRH receptor expression in postmenopausal ovaries it is possible that the decrease of the production of $\mathrm{T}$ in the postmenopausal ovary is a result of a direct down-regulation of the $\mathrm{GnRH}$-receptor signalling as a result of the administration of the GnRH agonist. Imai and co-workers already suggested that the administration of the GnRH agonist buserelin to normally cyclic women may exert a direct inhibitory effect on ovarian steroidogenesis by an action at the gonadal level (35). Similarly, Brus and co-workers found, in normally cycling women, that high affinity ovarian $\mathrm{GnRH}$ receptors are present predominantly in ovarian tissue following the $\mathrm{LH}$ surge (36).

In summary, it is concluded that in postmenopausal ovaries in vivo, steroidogenesis might be down-regulated by a direct action of high levels of a GnRH agonist. This observation should be confirmed by in vitro experiments.

\section{References}

1. Loosfelt H, Misrahi M, Atger M, Salesse R, Vu Hai-Luu Thi MT, Jolivet A, Guiochon-Mantel A, Sar S, Jallal B, Garnier J, Milgrom E. Cloning and sequencing of porcine LH-hCG receptor cDNA: variants lacking transmembrane domain. Science 1989;245:525-8.

2. McFarland KC, Sprengel R, Phillips HS, Köhler M, Rosemblit N, Nikolics K, Segaloff DL, Seeburg $\mathrm{PH}$. Lutropin-choriogonadotropin receptor: an unusual member of the $\mathrm{G}$ protein-coupled receptor family. Science 1989;245:494-9.

3. Sprengel R, Braun T, Nikolics K, Segaloff DL, Seeburg PH. The testicular receptor for follicle stimulating hormone: structure and functional expression of cloned cDNA. Mol Endocrinol 1990;4:525-30. 
4. Bukovsky A, Chen TT, Wimalasena J, Caudle MR. Cellular localization of luteinizing hormone receptor immunoreactivity in the ovaries of immature, gonadotropin-primed and normal cycling rats. Biol Reprod 1993;48:1367-82.

5. Kinnunen R, Karjalainen M, Rajaniemi H. Immunocytochemical localization of receptor-bound human chorionic gonadotropin in pseudopregnant rat ovaries. J Histochem Cytochem 1981;29: 9-16.

6. Danzo BJ, Midgley AR, Kleinsmith LJ. Human chorionic gonadotropin binding to rat ovarian tissue in vitro. Proceedings of the Society for Experimental Biology \& Medicine 1972;139:88-92.

7. Chomczynski P, Sacchi N. Single-step method of RNA isolation by acid guanidinium thiocyanatephenol-chloroform extraction. Anal Biochem 1987;162:156-9.

8. Themmen APN, Blok LJ, Post M, Baarends WM, Hoogerbrugge JW, Parmentier M, Vassart G, Grootegoed JA. Follitropin receptor down-regulation involves a cAMP-dependent posttranscriptional decrease of receptor mRNA expression. Mol Cell Endocrinol 1991;78:R7-R13.

9. Atger M, Misrahi M, Sar S, Le Flem L, Dessen P, Milgrom E. Structure of the human luteinizing hormone-choriogonadotropin receptor gene: unusual promotor and 5' non-coding regions. Mol Cell Endocrinol 1995;111:113-23.

10. Chi L, Zhou W, Prikhozhan A, Flanagan C, Davidson JS, Golembo M, Illing N, Millar RP, Sealfon SC. Cloning and characterization of the human GnRH receptor. Mol Cell Endocrinol 1993;91:R1R6.

11. Erba HP, Gunning P, Kedes L. Nucleotide sequence of the human gamma cytoskeletal actin mRNA; anomalous evolution of vertebrate non-muscle actin genes. Nucleic Acids Res 1986;14:5275-94.

12. Baarends WM, van Helmond MJL, Post M, van der Schoot PJCM, Hoogerbrugge JW, de Winter JP, Uilenbroek JThJ, Karels B, Wilming LG, Carel Meijers JH, Themmen APN, Grootegoed JA. A novel member of the transmembrane serine/threonine kinase receptor family is specifically expressed in the gonads and in mesenchymal cells adjacent to the müllerian duct. Development 1994;120:18997.

13. Lee CY, Coulam CB, Jiang NS, Ryan RJ. Receptors for human luteinizing hormone in human corpora lutea tissue. J Clin Endocrinol Metab 1973;36:148-52.

14. Cole FE, Weed JC, Schneider GT, Holland JB, Geary WL, Rice BF. The gonadotropin receptor of the human corpus luteum. Am J Obstet Gynecol 1973;117:87-95.

15. Wardlaw S, Lauersen NH, Saxena BB. The LH-hCG receptor of human ovary at various stages of he menstrual cycle. Acta Endocrinol 1975;79:568-76.

16. Rao ChV, Griffin LP, Carman Jr FR. Gonadotropin receptors in human corpora lutea of the menstrual cycle and pregnancy. Am J Obstet Gynecol 1977;128:146-53.

17. Halme J, Ikonen $M$, Rutanen EM, Seppälä $M$. Gonadotropin receptors of human corpus luteum during menstrual cycle and pregnancy. Am J Obstet Gynecol 1978;131:728-34.

18. Rajaniemi HJ, Rönnberg L, Kauppila A, Ylöstalo P, Jalkanen M, Saastamoinen J, Selander K, Pystynen P, Vihko R. Luteinizing hormone receptors in human ovarian follicles and corpora lutea during menstrual cycle and pregnancy. J Clin Endocrinol Metab 1981;108:307-13. 
19. Yamoto M, Nakano R, Iwasaki M, Ikoma H, Furukawa K. Luteinizing hormone receptors in human ovarian follicles and corpora lutea during the menstrual cycle. Obstet Gynecol 1986;68:200-3.

20. Shima K, Kitayama S, Nakano R. Gonadotropin binding sites in human ovarian follicles and corpora lutea during the menstrual cycle. Obstet Gynecol 1987;69:800-6.

21. Nakano R, Kitayama S, Yamoto M, Shima K, Ooshima A. Localization of gonadotropin binding sites in human ovarian neoplasms. Am J Obstet Gynecol 1989;161:905-10.

22. Vihko KK, Kujansuu E, Mörsky P, Huhtaniemi I, Punnonen R. Gonadotropins and gonadotropin receptors during the perimenopause. Eur J Endocrinol 1996;134:357-61.

23. Peluso JJ, Steger RW, Jaszczak S, Hafez ESE. Gonadotropin binding sites in human postmenopausal ovaries. Fertil Steril 1976;27:789-95.

24. Nakano R, Shima K, Yamoto M, Kobayashi M, Nishimori K, Hiraoka J-I. Binding sites for gonadotropins in human postmenopausal ovaries. Obstet Gynecol 1989;73:196-200.

25. Peng X-R, Hsueh AJW, LaPolt PS, Bjersing L, Ny T. Localization of luteinizing hormone receptor messenger ribonucleic acid expression in ovarian cell types during follicle development and ovulation. Endocrinology 1991;129:3200-7.

26. Minegishi T, Tano M, Abe Y, Nakamura K, Ibuki Y, Miyamoto K. Expression of luteinizing hormone/ human chorionic gonadotrophin (LH/HCG) receptor mRNA in the human ovary. Mol Hum Reprod 1997;3:101-7.

27. Minegishi T, Tano M, Igarashi M, Rokukawa S, Abe Y, Ibuki Y, Miyamato K. Expression of folliclestimulating hormone receptor in human ovary. Eur J Clin Invest 1997;27:469-74.

28. Kakar SS, Musgrove LC, Devor DC, Sellers JC, Neill JD. Cloning, sequencing, and expression of human gonadotropin releasing hormone (GnRH) receptor. Biochem Biophys Res Com1992;189:28995.

29. Peng C, Fan NC, Ligier M, Väänänen J, Leung PCK. Expression and regulation of gonadotropinreleasing hormone $(\mathrm{GnRH})$ and $\mathrm{GnRH}$ receptor messenger ribonucleic acids in human granulosaluteal cells. Endocrinology 1994;135:1740-6.

30. Whitelaw PF, Eidne KA, Sellar R, Smyth CD, Hillier SG. Gonadotropin-releasing hormone receptor messenger ribonucleic acid expression in rat ovary. Endocrinology 1995;136:172-9.

31. Minaretzis D, Jakubowski M, Mortola JF, Pavlou SN. Gonadotropin-releasing hormone receptor gene expression in human ovary and granulosa-lutein cells. J Clin Endocrinol Metab 1995;80:4304.

32. Fraser HM, Sellar RE, Illingworth PJ, Eidne KA. GnRH receptor mRNA expression by in-situ hybridization in the primate pituitary and ovary. Mol Hum Reprod 1996;2:117-21.

33. Imai A, Ohno T, Ohsuye K, Tamaya T. Expression of gonadotropin-releasing hormone receptor in human epithelial ovarian carcinoma. Ann Clin Biochem 1994;31:550-5.

34. Sluijmer AV, Heineman MJ, De Jong FH, Evers JLH. Endocrine activity of the postmenopausal ovary: the effects of pituitary down-regulation and oophorectomy. J Clin Endocrinol Metab $1995 ; 80: 2163-7$. 
35. Imai A, lida K, Tamaya T. Direct action of gonadotropin-releasing hormone (LH-RH) analogue on ovary: an alternative acting mechanism of buserelin. Arch Gynecol Obstet 1991;248:117-21.

36. Brus L, Lambalk CB, de Koning J, Helder MN, Janssens RMJ, Schoemaker J. Specific gonadotrophin-releasing hormone analogue binding predominantly in human luteinized follicular aspirates and not in human pre-ovulatory follicles. Hum Reprod 1997;12:769-73. 
CHAPTER 7

\section{GENERAL DISCUSSION}


The aim of this study was to investigate functional and morphological aspects of the postmenopausal ovary. The postmenopausal period of life is receiving much attention recently. The suppletion of oestrogens during the postmenopausal period appears to have a positive effect on the prevention of coronary heart disease, osteoporosis and Alzheimer's disease (1-6). For these reasons, oestrogen replacement therapy in postmenopausal women has been advocated. Inactivity of the postmenopausal ovary caused by a lack of active follicular growth is held responsible for the hypo-oestrogenic state in postmenopausal women. The assumption that a postmenopausal ovary is inactive and therefore redundant is not supported by the studies published. However, the results of these studies are conflicting.

In the present study we have addressed the following questions:

1. Does postmenopausal ovarian hormonal activity exist?

2. If so, to which degree is this activity related to ovarian morphology?

3. Do gonadotrophins still have a regulatory effect on this presumed postmenopausal ovarian activity?

4. Can gonadotrophin receptors be detected in the postmenopausal ovary?

The present study differs from other studies on these subjects in that one and the same group of patients was used to address all four questions mentioned.

The study was performed in postmenopausal women, all of whom underwent uni- or bilateral oophorectomy, with or without hysterectomy. Four patients were excluded for various reasons (withdrawal of informed consent, inadequate administration of the GnRH-agonist, two patients with an ovarian malignancy, one of whom had a granulosacell tumour).

\section{Does postmenopausal ovarian hormonal activity exist?}

To determine if the postmenopausal ovary has endocrine functions we had to develop a method to obtain blood from the ovarian veins during operation. The combined study of hormone concentrations in these ovarian veins, of hormone concentrations in peripheral veins, and the effect of oophorectomy on peripheral hormone levels provided information on the endocrine activity of an ovary. A sampling method was developed (chapter 2, section I) and shown to be adequate in a patient with a unilateral ovarian granulosa-cell tumour (chapter 2, section II). From our study we conclude that the postmenopausal ovary produces significant amounts of the androgens, A and T. No oestrogen production was found (chapter 4 , section I). This result is compared with the data from the literature in Table 1, which is the extended Table 1 from chapter 1. Our results are in agreement with the combined data of Judd et al. (7) and of Vermeulen (8) on peripheral hormone levels before and after oophorectomy, and with the in vitro data of Mattingly et al. (9). Comparison with literature done on ovarian vein levels of steroids in postmenopausal ovaries yields a less clear picture; especially because a number of authors did not indicate significance levels for the differences between ovarian and peripheral venous concentrations. Nevertheless, we conclude that our results on the 
Table 1. Review of the literature concerning postmenopausal ovarian production of oestrone (E1), oestradiol (E2), androstenedione (A), and testosterone ( $T$ ) together with the results of the present study.

\begin{tabular}{|c|c|c|c|c|}
\hline & $\begin{array}{c}\text { ovarian vs peripheral vein serum } \\
\text { levels }\end{array}$ & $\begin{array}{l}\text { before vs after oophorectomy } \\
\text { (one group of patients) }\end{array}$ & $\begin{array}{c}\text { before vs after oophorectomy } \\
\text { (diff. groups of patients) }\end{array}$ & in vitro studies \\
\hline Mattingly et al (1969) & & & & $A$ and $T$ production \\
\hline Rader et al (1973) & $E 1=; E 2=$ & & & \\
\hline Judd et al (1974) & $\begin{array}{l}E 1 \uparrow(P<0.05) ; E 2 \uparrow(P<0.05) \\
A \uparrow(\text { ns): } T \uparrow(P<0.01)\end{array}$ & & & \\
\hline Judd et al (1974) & & $T \downarrow(P<0.001) ; A \downarrow(P<0.001)$ & & \\
\hline Greenblatt et al (1976) & $\begin{array}{l}E 2= \\
A \uparrow(n s): T \uparrow \text { (ns) }\end{array}$ & & & \\
\hline Vermeulen et al (1976) & & & $\begin{array}{l}E 1=: E 2= \\
A \downarrow(P<0.01) ; T \downarrow(P<0.01)\end{array}$ & \\
\hline Judd et al (1976) & & $E_{1}=; E 2=$ & & \\
\hline Dennefors et al (1980) & & & & E2 and $A$ production \\
\hline Longcope et al (1980) & $\begin{array}{l}E 1=: E 2 \uparrow(s ?) \\
A=: T \uparrow(s ?)\end{array}$ & & & \\
\hline Lucisano et al (1984) & $\begin{array}{l}E 1 \uparrow(P<0.01) ; E 2 \uparrow(P<0.001) \\
\text { A } \uparrow(P<0.01): T \uparrow(P<0.001)\end{array}$ & & & \\
\hline Aiman et al (1986) & $\begin{array}{l}E 1=; E 2 \uparrow(s ?) \\
A=; T \uparrow(s ?)\end{array}$ & & & \\
\hline Present study (1999) & 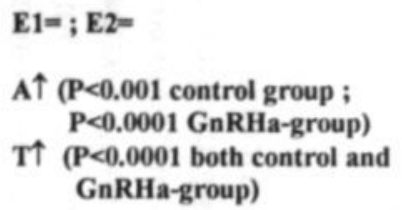 & $\begin{array}{c}\text { E1 } \downarrow \text { (P<0.01 control group) } \\
\text { E2 } \downarrow \text { (P<0.01 control group) } \\
\text { T } \downarrow \text { (P<0.0001 control group ; } \\
\quad \mathrm{P}<0.05 \text { GnRHa-group) }\end{array}$ & & \\
\hline
\end{tabular}


largests series of women reported support the general observation of non-significant secretion of oestrogens, whereas both $\mathrm{T}$ and $\mathrm{A}$ are secreted in significant amounts by postmenopausal ovaries.

However, we have to consider that the ovarian veins not only drain the ovary but also part of the uterus. It is therefore preferable to speak of venous sampling of the utero-ovarian venous plexus. If a hormone concentration is increased in an ovarian vein compared with the peripheral serum levels, this proves ovarian secretion of the hormone. Another question is whether this ovarian secretion forms also a significant contribution to the total production of the steroid in the body. Production is the sum of secretion of a hormone by endocrine glands (ovaries, adrenal glands) together with its peripheral formation by conversion of precursor steroids. For the calculation of hormone secretion by a gland it is important to know the blood flow through that organ in 24 hours. No exact data are known about the blood flow through a postmenopausal ovary in 24 hours. Baird et al. calculated an ovarian plasma flow of $60 \mathrm{~L} /$ day in premenopausal women, but ovarian plasma flow in postmenopausal women is probably below $10 \%$ of that (10). The secretion of an androgen by the ovary will only influence the peripheral serum level of that androgen if the ovarian production is really substantial compared with non-ovarian sources of that same androgen. The peripheral level of $T$ six weeks after operation was significantly lower than the poriphoral lovel of $T$ boforo oporation. This indivates that the production of $\mathrm{T}$ by the postmenopausal ovary must have been substantial, whereas this was not the case for $\mathrm{A}$.

It would be interesting to know whether the ovarian vein levels of $A$ and $T$ will change with postmenopausal age and with time after menopause. In a group of 680 postmenopausal women no correlations were found between E1, E2, A, and postmenopausal age (11). However, because in that study only peripheral serum hormone levels were measured, the source of steroid production (i.e. ovarian vs adrenal gland) is uncertain. By measurement of ovarian vein levels of A and T in 20 postmenopausal women we were not able to demonstrate an age related change (chapter $\mathbf{4}$, section II). In order to determine whether postmenopausal ovarian androgen production is influenced by postmenopausal age or time after menopause, a larger group of patients with ovarian vein sampling should be studied.

In conclusion: The postmenopausal ovary produces significant amounts of $A$ and $\mathrm{T}$, although only $\mathrm{T}$ contributes significantly to its peripheral serum levels. We were not able to demonstrate a relation between pelvic $A$ and $T$ levels with either chronological or postmenopausal age.

If so, to which degree is postmenopausal hormonal activity related to ovarian morphology?

Previous studies have been published in which the relationship between ovarian histology and endometrium pathology was investigated (12-15). It has been demonstrated 
that the increased risk of endometrial cancer is caused by (1) an increased endogenous oestrogen production caused by oestrogen producing tumours, (2) the increased peripheral aromatization of A, such as occurs in obesity, or (3) a prolonged exogenous administration of oestrogens unopposed by progestational agents (16-19). Several studies have focussed on the relationship between endogenous ovarian hormone production and endometrial cancer $(7,20)$. There is one study in which the ovarian morphology has been correlated with ovarian steroid production by measuring hormone levels in the ovarian veins (21). This investigation demonstrated significant differences for serum levels of E1, E2, A, and $\mathrm{T}$ between the ovarian and peripheral veins. The ovarian vein levels of E1, E2, and A were significantly higher in ovaries with moderate-severe stromal hyperplasia compared with those of atrophic ovaries. This difference was not found for T levels. From our study (chapter 5) it was concluded that the postmenopausal ovary does not produce oestrogens and that only the ovarian vein levels of $\mathrm{A}$ and $\mathrm{T}$ were significantly higher in ovaries with moderate-severe stromal hyperplasia compared with atrophic ovaries. The question arises whether these higher androgen levels play a direct role in the etiology of endometrial carcinoma. In a related study, we have reported that compared with women with benign gynaecological conditions, the ovarian vein serum levels of A and $\mathrm{T}$ were elevated in women with endometrial cancer (22), as was already suggested by Nagamani et al. (20). It is possible that the higher levels of androgens are aromatized in fat tissue to oestrogens, which play a role in the etiology of endometrial cancer. However, results of immuno-histochemical techniques indicate that also androgen receptors are present in the endometrium $(23,24)$. Therefore, the androgens produced by the ovarian stroma might play a direct etiological role in endometrial cancer. Alternatively, it is also possible that the conversion of androgens into oestrogens occurs locally in the endometrium. Tseng et al. found that the human endometrium can synthesize oestrogens from $\mathrm{T}$ and $\mathrm{A}$ at a concentration equal to plasma levels (25). The capacity for aromatization in neoplastic endometrium is 2-5 times higher than that in normal endometrium (26), and $\mathrm{T}$ also inhibits 17ß-hydroxysteroid dehydrogenase activity competitively in endometrium, which would result in reduced oxidation of E2 to E1, with accumulation of E2 in endometrial tissue (27).

Future research should focus on the relationship between ovarian morphology, local androgen levels and carcinoma of the endometrium together with studies investigating the possible direct proliferative effect of androgens on the endometrium or the possible proliferative effect of increased local endometrial oestrogen synthesis resulting from increased aromatase activity in the endometrium.

In conclusion: The amount of stromal hyperplasia in postmenopausal ovaries is correlated with the ovarian vein levels of $A$ and $T$. Morphological characteristics of the postmenopausal ovary are correlated with the local (i.e. pelvic) endocrine milieu and may play a role in the etiology of hormone-dependent diseases of the internal genitals. 
The putative regulatory effect of gonadotrophins on ovarian steroid production was investigated by pituitary down regulation with a single depot-dose of a $\mathrm{GnRHa}$ two weeks before operation. The effects of the administration of human chorionic gonadotrophin on ovarian steroid secretion (eg oestrogen), was first documented in postmenopausal women by Poliak et al. (28), later followed by studies on the effect of GnRHa (29,30). Gonadotrophin levels were determined in 17 postmenopausal women before and after administration of a single depot-dose of the GnRHa triptorelin (chapter 3). A significant decrease of LH and FSH levels in postmenopausal women was obtained after two weeks.

The effect of administering hCG or GnRHa on circulating peripheral serum oestrogen and androgen levels has been reported in several studies $(8,28,31,32)$. However, no studies have been performed in which the possible regulatory effect of gonadotrophins on ovarian venous hormone levels has been investigated by creating a hypogonadotrophic state. In our study (chapter $\mathbf{4}$, section I) we found that $\mathrm{T}$ production by the postmenopausal ovary is reduced after suppression of the high levels of circulating gonadotrophins; the adrenal glands also produce significant amounts of $\mathrm{T}$, but these organs are not under gonadotrophic control. The absence of effect on peripheral levels of A may be due to the relatively large adrenal contribution to the circulating levels of this steroid.

In conclusion: we demonstrated a significant decrease of LH and FSH serum levels in postmenopausal women within two weeks after administration of a single depotdose of the GnRH agonist triptorelin. The production of $T$ by the postmenopausal ovary is in part stimulated by the high levels of circulating gonadotrophins.

Can gonadotrophin receptors be detected in the postmenopausal ovary?

Some studies showed an increase in postmenopausal ovarian steroid production after the administration of hCG (28,33). Because in our study (chapter 4, section I) a regulating effect of gonadotrophins was found on the ovarian testosterone production we expected to find gonadotrophin receptors in postmenopausal ovarian tissue (chapter 6). After incubation of postmenopausal ovarian tissue slices with ${ }^{125} \mathrm{I}$-labeled hormones, no FSH and LH receptors were detected by autoradiography (chapter 6). A method failure was less likely because rat ovarian sections were used as a control with normal results for the detection of $\mathrm{LH}$ and FSH receptors. Our results were in agreement with the study by Vihko and co-workers (34).

Using RNase protection experiments on a different set of postmenopausal ovaries, full length FSH receptor mRNA was found to be present but -not significantly- lower compared with premenopausal ovaries. Full length LH receptor mRNA expression was at background level. However, expression of LH receptor mRNA splice variants 1, 2, 
and 3 was detected in the postmenopausal ovaries. These splice variants lack essential exons and they will therefore not be able to convey the LH signal to the inside of the cell.

This is the first study in postmenopausal ovaries in which GnRH mRNA receptor expression was found using the RNase protection method (chapter 6). It is possible that the decrease of the production of $\mathrm{T}$ in the postmenopausal ovary is a result of a direct down-regulation of $\mathrm{GnRH}$-receptor signalling as a result of the administration of the $\mathrm{GnRH}$ agonist. In vitro studies will clarify whether the administration of a GnRHa directly to incubated cultures of postmenopausal ovarian cells will result in a higher testosterone production by these cells.

In conclusion: GnRH receptor mRNA expression was demonstrated in postmenopausal ovaries by using RNase protection. Probably GnRH and GnRH agonists not only have an indirect effect on postmenopausal function (via LH and FSH) but also have a direct effect on postmenopausal hormone production.

From the present investigation we conclude that the postmenopausal ovary is not inactive in terms of steroid (i.e. predominantly androgen) production. Ovarian testosterone production is gonadotrophin-driven and contributes significantly to the levels of $T$ in the circulation. It is therefore tempting to speculate that ovarian $\mathrm{T}$ plays a role in postmenopausal health.

\section{Summary of suggestions for future research:}

* measuring ovarian blood flow in postmenopausal women in order to be able to calculate ovarian production of the androgens $A$ and $T$ studying the influence of postmenopausal age and time after menopause on the ovarian androgen production by performing ovarian vein sampling in a larger group of patients investigating the relationship between ovarian morphology, local androgen levels and carcinoma of the endometrium together with studies investigating the possible direct proliferative effect of androgens on the endometrium or the possible proliferative effect caused by increased local endometrium oestrogen levels as a result of increased aromatase activity in the endometrium studying in vitro whether direct administration of $\mathrm{GnRHa}$ to cultures of postmenopausal ovarian cells will result in a higher androgen production by these cells 


\section{References}

1. Grodstein F, Stampfer MJ, Manson JE, Colditz GA, Willett WC, Rosner B, Speizer FE, Hennekens $\mathrm{CH}$. Postmenopausal estrogen and progestin use and the risk of cardiovascular disease. N Engl J Med 1996;335:453-61.

2. Lindsay R, Hart DM, Aitken JM, MacDonald EB, Anderson JB, Clarke AC. Long-term prevention of postmenopausal osteoporosis by oestrogen: evidence for an increased bone mass after delayed onset of oestrogen treatment. Lancet 1976;i: 1038-41.

3. Weiss NS, Ure CL, Ballard JH, Williams AR, Daling JR. Decreased risk of fractures of the hip and lower forearm with postmenopausal use of estrogen. N Engl J Med 1980; 303:1195-8.

4. Christiansen C, Christensen MS, Transbol I. Bone mass in postmenopausal women after withdrawal of oestrogen/gestagen replacement therapy. Lancet 1981;i:459-61.

5. Tang M-X, Jacobs D, Stern Y, Marder K, Schofield P, Gurland B, Andrews H, Mayeux R. Effect of oestrogen during menopause on risk and age at onset of Alzheimer's disease. Lancet 1996;348:42932.

6. Kawas C, Resnick S, Morrison A, Brookmeyer R, Corrada M, Zonderman A, Bacal C, Lingle DD, Metter E. A prospective study of estrogen replacement therapy and the risk of developing Alzheimer's disease: the Baltimore longitudinal study of aging. Neurology 1997;48:1517-21.

7. Judd HL, Lucas WE, Yen SSC. Effect of oophorectomy on circulating testosterone and androstenedione levels in patients with endometrial cancer. Am J Obstet Gynecol 1974;118:793-8.

8. Vermeulen A. The hormonal activity of the postmenopausal ovary. J Clin Endocrinol Metab 1976;42:247-53.

9. Mattingly RF, Huang WY. Steroidogenesis of the menopausal and postmenopausal ovary. Am J Obstet Gynecol 1969;103:679-93.

10. Baird DT, Fraser IS. Blood production and ovarian secretion rates of estradiol-17B and estrone in women throughout the menstrual cycle. J Clin Endocrinol Metab 1974;38:1009-17

11. Kwekkeboom DJ, de Jong FH, van Hemert AM, Vandenbroucke JP, Valkenburg HA, Lamberts SWJ. Serum gonadotropins and $\alpha$-subunit decline in aging normal postmenopausal women. J Clin Endocrinol Metab 1990;70:944-50.

12. Hertig AT. The aging ovary: a preliminary note. J Clin Endocrinol 1944;4:581-2.

13. Woll E, Hertig AT, Smith GVS, Johnson LC. The ovary in endometrial carcinoma: with notes on the morphological history of the aging ovary. Am J Obstet Gynecol 1948;56: 617-33.

14. Novak ER, Mohler DI. Ovarian stromal changes in endometrial cancer. Am J Obstet Gynecol 1953;65:1099-110.

15. Marcus CC. Ovarian cortical stromal hyperplasia and carcinoma of the endometrium. Obstet Gynecol $1963 ; 21: 175-86$. 
16. Hammond CB, Jelovsek FR, Lee KL, Creasman WT, Parker RT. Effects of long-term estrogen replacement therapy: neoplasia. Am J Obstet Gynecol 1979;133:537-47.

17. Judd HL, Davidson BJ, Frumar AM, Shamonki IM, Lagasse LD, Ballon SC. Serum androgens and estrogens in postmenopausal women with and without endometrial cancer. Am J Obstet Gynecol 1980;136:859-71.

18. Ingraham CB, Black WC, Rutledge EK. The relationship of granulosa-cell tumors of the ovary to endometrial carcinoma. Am J Obstet Gynecol 1944;48:760-73.

19. MacDonald PC, Edman CD, Hemsell DL, Porter JC, Siiteri PK. Effect of obesity on conversion of plasma androstenedione to estrone in postmenopausal women with and without endometrial cancer. Am J Obstet Gynecol 1978;130:448-55.

20. Nagamani M, Hannigan EV, Dillard EA, van Dinh T. Ovarian steroid secretion in postmenopausal women with and without endometrial cancer. J Clin Endocrinol Metab 1986;62:508-12.

21. Lucisano A, Russo N, Acampora MG, Fabiano A, Fattibene M, Parlati E, Maniccia E, Dell'Acqua S. Ovarian and peripheral androgen and oestrogen levels in postmenopausal women: correlations with ovarian histology. Maturitas 1986; 8:57-65.

22. Heineman MJ, Sluijmer AV, Kampschöer PHNM, de Jong FH, Evers JLH. Utero-ovarian vein blood sampling in postmenopausal women with and without endometrial cancer. Fertil Steril 1995;Suppl:S92(Abstract O-187).

23. Horie K, Takakura K, Imai K, Liao S, Mori T. Immunohistochemical localization of androgen receptor in the human endometrium, decidua, placenta and pathological conditions of the endometrium. Hum Reprod 1992;7:1461-6.

24. Mertens HJMM, Heineman MJ, Koudstaal J, Theunissen P, Evers JLH. Androgen receptor content in human endometrium. Eur J Obstet Gynecol Reprod Biol 1996;70:11-3.

25. Tseng L, Mazella J, Mann WJ, Chumas J. Estrogen synthesis in normal and malignant human endometrium. J Clin Endocrinol Metab 1982;55:1029-31.

26. Tseng L, Mazella J, Funt MI, Mann WJ, Stone ML. Preliminary studies of aromatase in human neoplastic endometrium. Obstet Gynecol 1984;63:150-4.

27. Tseng L, Mazella J, Tseng L. Kinetic studies of human endometrial hydroxysteroid dehydrogenase. J Steroid Biochem 1981;14:437-42.

28. Poliak A, Jones GES, Goldberg B, Solomon D, Woodruff JD. Effect of human chorionic gonadotropin on postmenopausal women: ovarian histochemistry and urinary hormone excretion. Am J Obstet Gynecol 1968;101:731-9.

29. Happ J, Scholz P, Weber T, Cordes U, Schramm P, Neubauer M, Beyer J. Gonadotropin secretion in eugonadotropic human males and postmenopausal females under long-term application of a potent analog of gonadotropin-releasing hormone. Fertil Steril 1978;30:674-8.

30. Bergquist C, Nillius SJ, Wide L. Reduced gonadotropin secretion in postmenopausal women during reatment with a stimulatory LRH analogue. J Clin Endocrinol Metab 1979;49:472-4. 
31. Plowman PN, Nicholson RI, Walker KJ. Remission of postmenopausal breast cancer during treatment with the luteinising hormone releasing hormone agonist ICI 118630. Br J Cancer 1986;54:903-9.

32. Waxman JH, Harland SJ, Coombes RC, Wrigley PFM, Malpas JS, Powles T, Lister TA. The treatment of postmenopausal women with advanced breast cancer with buserelin. Cancer Chemother Pharmacol 1985;15:171-3.

33. Dennefors BL, Janson PO, Knutson F, Hamberger L. Steroid production and responsiveness to gonadotropin in isolated stromal tissue of human postmenopausal ovaries. Am J Obstet Gynecol 1980;136:997-1002.

34. Vihko KK, Kujansuu E, Mörsky P, Huhtaniemi I, Punnonen R. Gonadotropins and gonadotropin receptors during the perimenopause. Eur J Endocrinol 1996;134:357-61. 


\section{SUMMARY}


In this study the function of the postmenopausal ovary was investigated. To this end, peripheral vein blood samples were taken from postmenopausal women who, for various reasons, had to undergo surgery. The samples were taken two weeks before, during and after surgery. During surgery, also ovarian vein blood samples were collected. To attain pituitary down-regulation, a single dose of a $\mathrm{GnRH}$ agonist ( $3.75 \mathrm{mg}$ triptoreline IM as a depot-dose) was administered to a number of randomly selected patients.

In chapter 2, section I a description is given of how ovarian vein blood was sampled during surgery. To determine the selectivity of the procedure, the peripheral and ovarian vein levels of androstenedione in 32 patients were compared. The results confirm the validity of the test. In virtually all cases, the method to obtain utero-ovarian blood samples was successful and without complications.

The clinical relevance of the sampling method, described in chapter 2, section II was accidentally established in the case of a patient with a small granulosa cell carcinoma in the right ovary. After comparing the peripheral and ovarian vein levels of inhibin, the former appeared to be in the premenopausal range. In contrast with the left ovarian vein, the inhibin levels in the right ovarian vein were increased substantially. This finding made us conclude that inhibin is a potential early marker for granulosa-cell tumours. The more so since, although the peripheral serum inhibin levels in this patient had obviously changed, this was accompanied by an increase in oestradiol. We were able to locate the specific site of inhibin production, i.e. the granulosa-cell tumour.

There is practically no literature on the effects of $\mathrm{GnRHa}$ (gonadotropin releasing hormone agonist) administration to postmenopausal women. Chapter 3 details the results of an investigation among seventeen patients into the effects of $\mathrm{GnRHa}$ administration to postmenopausal women. Two weeks after administration, the serum gonadotrophin levels were suppressed to premenopausal levels. Despite their upward trend, eight weeks after administering a single depot-dose of the GnRHa, the LH and FSH serum levels were still substantially lower than before.

Chapter 4, section I explores the endocrine activity of the postmenopausal ovary and the effect of down-regulation of gonadotrophin secretion. These were studied in a group of 35 postmenopausal women, to fifteen of whom a single depot-dose of GnRHa was administered two weeks before surgery. The remaining twenty women served as controls. The investigation revealed that the postmenopausal ovary produces considerable amounts of androstenedione (A) and testosterone (T), although oophorectomy was observed to have a major effect on peripheral serum levels of $\mathrm{T}$ only. The high levels of circulating gonadotrophins are to some degree accountable for the stimulation of $\mathrm{T}$ production although pituitary down-regulation does not altogether eliminate androgenic activity.

Chapter 4, section II considers the effects of chronological age and time after menopause on ovarian vein androgen levels. These were examined in (a small group of) 20 postmenopausal patients. On the basis of the results, however, it is not possible to relate pelvic androstenedione and testosterone levels to either chronological age or time after menopause. 
In 18 postmenopausal women a possible correlation was studied between the concentrations of oestrogens and androgens in the ovarian vein, and the ovarian degree of stromal hyperplasia. In chapter $\mathbf{5}$ details of the study are given revealing a connection between the amount of stromal hyperplasia in postmenopausal ovaries and the production of androstenedione and testosterone. A higher degree of stromal hyperplasia is accompanied by an increase in androstenedione and testosterone concentrations in the ovarian veins. No relation was found between the concentration of oestrone/oestradiol and the amount of stromal hyperplasia. It is suggested that morphological characteristics of the menopausal ovary determine the local endocrine status and may play a role in the etiology of carcinoma of the endometrium.

The presence of $\mathrm{LH}, \mathrm{FSH}$, and $\mathrm{GnRH}$ receptors was studied in postmenopausal ovaries (chapter 6). In ten postmenopausal ovaries no LH or FSH receptors were found by autoradiographic detection using ${ }^{125} \mathrm{I}$-labeled hormones. In seven other postmenopausal ovaries using the RNase protection method, expression of full length FSH and GnRH receptor mRNA was found. Only expression of splice variants of LH receptor mRNA were present. It was postulated that $\mathrm{GnRH}$ and $\mathrm{GnRHa}$ not only have an indirect effect on postmenopausal ovarian function (via $\mathrm{LH}$ and $\mathrm{FSH}$ ) but also may have a direct effect on postmenopausal ovarian hormone production. 
SAMENVATTING 
Bij dit onderzoek stond de functie van het postmenopauzaal ovarium centraal. Om deze te meten werden bij postmenopauzale vrouwen, die om uiteenlopende redenen een operatie moesten ondergaan, perifere veneuze bloedmonsters afgenomen, namelijk twee weken voor, tijdens en na de operatie. Ook werden tijdens de operatie ovariële veneuze bloedmonsters afgenomen. Met het oog op down-regulatie van de hypofyse kreeg een aantal -at random gekozen- patiënten eenmalig een $\mathrm{GnRH}$ agonist toegediend.

Hoofdstuk 2, sectie I beschrijft de methode waarmee tijdens de operatie ovarieel bloed werd afgenomen. Om de selectiviteit van de procedure vast te stellen, werden de perifere en ovariële serum spiegels van androsteendion bij 32 patinten met elkaar vergeleken. De validiteit van de test werd bevestigd. De methode werd in nagenoeg alle gevallen met succes uitgevoerd en er traden geen complicaties op.

De klinische relevantie van deze methode van sampling wordt geillustreerd aan een patiënte met een granulosacelcarcinoom in het rechter ovarium, bij wie de perifere en ovariële metingen van inhibine met elkaar werden vergeleken (Hoofdstuk 2, sectie II). De perifere concentratie van inhibine bevond zich in de premenopauzale range. In serum uit de rechter ovariële plexus waren de waarden van inhibine echter significant hoger dan die in de linker ovariële veneuze plexus. Op grond van deze bevinding werd vastgesteld dat inhibine al mogelijk in een vroeg stadium kan duiden op de aanwezigheid van een granulosaceltumor, met name omdat het bij deze patiënte ging om een waarneembare verandering (t.o.v. de postmenopauzale normaalwaarden) van de concentratie van inhibine in perifeer bloed zonder dat dit gepaard ging met een verhoogd oestradiol. De plek waar inhibine werd aangemaakt, namelijk een kleine granulosaceltumor, werd precies gelokaliseerd.

Er is nog zeer weinig onderzoek gedaan naar de effecten van toediening van een GnRH agonist aan postmenopauzale patiënten. Hoofdstuk 3 belicht de resultaten van een onderzoek hiernaar onder 17 postmenopauzale patiënten. De patiënten kregen eenmalig een $\mathrm{GnRH}$ agonist (GnRHa) in de vorm van een depot-preparaat toegediend. Twee weken na toediening werden de effecten gemeten. Hierbij bleek dat de gonadotropinewaarde in het bloed gedaald was en zich in de premenopauzale range bevond. Acht weken na toediening van de GnRHa vertoonden de LH- en FSH-spiegels in het bloed weliswaar wederom een stijgende lijn, maar waren zij nog steeds significant lager dan de waarden vóór toediening van de agonist.

Hoofdstuk 4, sectie I beschrijft een deelonderzoek bij 35 postmenopauzale vrouwen naar de endocriene werking van het postmenopauzaal ovarium en de invloed van down-regulatie van de hypofyse. Van de deelnemers kregen vijftien vrouwen twee weken voor hun operatie een eenmalige depot-dosis GnRHa. De overige twintig vrouwen fungeerden als controlegroep. Uit dit onderzoek kwam naar voren dat het postmenopauzaal ovarium aanzienlijke hoeveelheden androsteendion (A) en testosteron (T) secreteert, ofschoon alleen $\mathrm{T}$ een significante bijdrage levert aan de $\mathrm{T}$ waarden in perifeer bloed. De productie van dergelijke hoeveelheden $\mathrm{T}$ door het postmenopauzaal ovarium wordt gestimuleerd door de hoge gonadotropinen spiegels in de circulatie hoewel downregulatie van de hypofyse de $\mathrm{T}$ productie niet volledig onderdrukt. 
Hoofdstuk 4, sectie II brengt de resultaten in kaart van een studie bij 20 postmenopauzale patiënten. Hierbij werd gekeken naar de invloed van leeftijd en tijd na de menopauze op de androgene waarden in ovarieel bloed. Er kon (in deze kleine groep) geen verband tussen deze twee grootheden en de androsteendion- en testosteronwaarden in het bekken worden aangetoond.

In hoofdstuk 5 wordt een onderzoek beschreven naar een eventueel verband tussen de concentraties van oestrogenen en androgenen in het ovariële bloed en de mate van stroma hyperplasie van het ovarium. Het onderzoek werd uitgevoerd bij achttien postmenopauzale vrouwen. Geconcludeerd werd dat de mate van stroma hyperplasie in het postmenopauzaal ovarium gelijke tred houdt met de productie van androsteendion en testosteron: hoe meer stroma hyperplasie, des te hoger de concentraties androsteendion en testosteron in het ovariële bloed. Er werd geen relatie aangetroffen tussen de oestron of oestradiol concentraties en de mate van stromale hyperplasie. Er wordt gesuggereerd dat morfologische karakteristieken van het postmenopauzaal ovarium het lokale endocriene milieu beïnvloeden en dat zij een rol spelen in de etiologie van het endometriumcarcinoom.

Een studie naar de aanwezigheid van $\mathrm{LH}, \mathrm{FSH}$ en GnRH receptoren in postmenopauzale ovaria is beschreven in hoofdstuk 6. Met het gebruiken van ${ }^{125} \mathrm{I}$ gelabelde hormonen werden geen LH en FSH receptoren aangetoond in tien postmenopauzale ovaria. In zeven andere postmenopauzale ovaria werd met behulp van de RNase protection methode expressie van 'full length' FSH receptor mRNA en van GnRH receptor mRNA aangetoond. Van het LH receptor mRNA werden alleen 'splice variants' aangetroffen. Mogelijk hebben GnRH of GnRHa niet alleen een indirect effect op de functie van het postmenopauzaal ovarium (via LH en FSH), maar hebben zij ook een direct effect op de hormoonproduktie van het postmenopauzaal ovarium via deze GnRH receptoren. 


\section{CURRICULUM VITAE}

De schrijver van dit proefschrift werd op 23 juni 1959 geboren te Apeldoorn. In 1978 behaalde hij het VWO diploma aan het Johannes Calvijn Lyceum te Kampen. In het zelfde jaar begon hij met zijn studie Geneeskunde aan de Rijksuniversiteit Groningen. Tijdens deze studie is hij student-assistent geweest op de afdelingen Fysiologische Chemie, Medische Microbiologie en Gynaecologie/Verloskunde. In augustus 1986 werd het artsexamen gehaald. Van oktober 1986 tot maart 1988 is hij arts-assistent niet in opleiding geweest op de afdelingen Gynaecologie/Verloskunde van het Ziekenhuis de Weezenlanden te Zwolle en het De Wever Ziekenhuis te Heerlen. Van maart 1988 tot januari 1992 heeft hij gewerkt als arts-assistent in opleiding tot gynaecoloog in het De Wever Ziekenhuis te Heerlen met als opleider dr. J.E.G.M. Stoot. Daarna heeft hij tot maart 1993 gewerkt als arts-assistent in opleiding tot gynaecoloog in het Academisch Ziekenhuis te Maastricht met als opleider Prof. Dr. J. de Haan. Op 1 maart 1993 werd hij ingeschreven als gynaecoloog in het specialistenregister. Hij is daarna direct opgenomen in de maatschap van gynaecologen (in associatie met A.J.A. Douglas, P.J.M. Huybregts en mw. A.W.C Wester) in het Wilhelmina Ziekenhuis te Assen waar hij nog steeds werkzaam is. Zijn interesse ligt vooral bij de infertiliteit en de endoscopische chirurgie. In 1994 won hij op het ESHRE congres te Brussel 'The Ferring GnRH Analogue award". 


\section{ADDENDUM 1}

Patiënten folder samengesteld samen met het patiënten-voorlichtingsbureau van het De Wever-Ziekenhuis te Heerlen. 


\section{ONDERZOEK NAAR DE FUNCTIE VAN \\ EIERSTOKKEN NA DE OVERGANG}

\section{INLEIDING}

Eierstokken spelen in het leven van de vrouw een belangrijke rol. Met name in de vruchtbare levensfase zijn zij onontbeerlijk. Naast het maken van eitjes, produceren zij ook hormonen.

De leeftijd waarin een vrouw in de overgang komt is afhankelijk van de hoeveelheid eitjes die zich in de eierstokken bevinden. Wanneer de eitjes in de eierstokken op zijn, raakt een vrouw in de overgang. Men heeft altijd aangenomen dat eierstokken na de overgang nauwelijks nog hormonen maken en dus net zo goed kunnen worden verwijderd. De laatste tijd verschijnen er echter studies die vermelden dat eierstokken na de overgang zeker nog hormonen maken en dus actief zijn. Welke hormonen zij maken en hoeveel is nog onduidelijk.

\section{DOEL VAN HET ONDERZOEK}

De afdeling Gynaecologie/Obstetrie van het De Wever-Ziekenhuis is 1 januari 1990 gestart met een onderzoek naar de functie van eierstokken na de overgang.

Het doel van dit onderzoek is om op een nieuwe manier de functie van de eierstokken na de overgang zo volledig mogelijk in kaart te brengen. Wij hopen hiermee een zinvolle bijdrage te leveren aan het medisch vraagstuk of eierstokken na de overgang nog een functie hebben of niet.

\section{WIE KUNNEN MEEDOEN?}

Alleen vrouwen, die na de overgang zijn en om een medische reden aan baarmoeder en eierstokken moeten worden geopereerd, kunnen aan dit onderzoek medoen.

\section{WAT HOUDT HET ONDERZOEK IN?}

Het onderzoek bestaat uit:

* Het samen met de arts invullen van een vragenlijst

* Het eenmalig via een injectie toedienen van een hormoonpreparaat waardoor de productie van hormonen door de eierstokken wordt stilgelegd. Dit hormoonpreparaat wordt vaak gebruikt bij de behandeling van vrouwen met vruchtbaarheidsproblemen; bijwerkingen komen niet of nauwelijks voor.

* Enkele malen wordt bloed afgenomen om hierin hormoonspiegels te kunnen bepalen. Deze controles worden vrijwel geheel in het routine-bloedonderzoek ingepast, waardoor er zo min mogelijk hoeft te worden geprikt.

* Na de operatie zullen de eierstokken door de patholoog-anatoom worden onderzocht om de productieplaats van de hormonen te kunnen vaststellen. 


\section{CONSEQUENTIES VOOR DE PATIËNT}

Zoals reeds vermeld, kunnen aan dit onderzoek alleen patiënten meedoen die na de overgang geopereerd worden aan baarmoeder en eierstokken. Er kan pas met onderzoek worden begonnen als de patiënt hiervoor schriftelijk haar toestemming heeft gegeven. Twee weken na de injectie vindt de operatie plaats. Bij een deel van de patiënten zal het gaan om een kwaadaardige aandoening van de baarmoeder. Bij hen zal de noodzaak tot operatie worden gesteld na een curettage. In de praktijk bedraagt de wachttijd tussen curettage en operatie minimaal twee weken. Door dit onderzoek zal deze periode niet worden verlengd. Bekend is overigens dat een kwaadaardig gezwel van de baarmoeder dermate langzaam groeit dat een tijdsduur van 2 weken tussen diagnose en therapie medisch gezien geen consequenties heeft.

\section{VOORUITGANG DANKZIJ ONDERZOEK}

Dit onderzoek heeft voor u persoonlijk geen nut, met andere woorden: $u$ wordt er niet beter van. Door deel te nemen aan dit onderzoek levert $u$ wèl een bijdrage aan het oplossen van een medisch vraagstuk.

Vooruitgang in de geneeskunde is alleen mogelijk dankzij onderzoeken waaraan patiënten deelnemen. Wij denken met dit onderzoek een nuttige bijdrage aan de geneeskunde te kunnen leveren en aan de gynaecologie in het bijzonder. Het onderzoek is bovendien zodanig opgezet dat het voor u nauwelijks belastend is.

\section{VERANTWOORDELIJK}

Het onderzoek wordt verricht onder verantwoordelijkheid van de maatschap gynaecologie van het De Wever-Ziekenhuis door dr M.J. Heineman, gynaecoloog en door A.V. Sluijmer, arts-assistent in opleiding tot gynaecoloog.

Dokter Sluijmer zal patiënten, die aan het onderzoek deelnemen, begeleiden waar het dit onderzoek betreft. Van te voren heeft hij een uitgebreid gesprek met u waarin u uw vragen kwijt kunt. Uw eigen gynaecoloog blijft verder, wat uw aandoening betreft, voor u zorgen.

Deelname aan dit onderzoek wordt enorm op prijs gesteld maar is geheel vrijblijvend. Wij nemen het u niet kwalijk wanneer u niet wenst deel te nemen. Natuurlijk zal dit geen gevolgen hebben voor uw behandeling. 


\section{INFORMED CONSENT}

Ondergetekende geeft hierbij haar schriftelijke toestenming voor deelname aan het onderzoek getiteld "Ageing Gonads", een onderzoek ıaar de functie van eierstokken na de overgang.

Zij verklaart tevens kennis te hebben genomen van dipatiëntenbrochure en mondeling voldoende te zijn ingelicht over het onderzoek.

Naam:

Adres:

Geboortedatum:

Handtekening: 
ADDENDUM 2 


\section{PROJEKT AGEING GONADS}

\section{IDENTIFICATIENUMMER}

\section{GROEPSNUMMER}

\section{Identificatie}

* identificatienummer :

* ziekenhuis

* naam

* geboortedatum

* nationaliteit

* postcode

\section{Algemene voorgeschiedenis en anamnese}

1. Voorgeschiedenis

* tr. circulatorius : medicatie :

* hypertensie medicatie :

* tr. respiratorius :

* tr. digestivus medicatie :

* tr.urogenitalis medicatie :

\section{* CZS} medicatie :

* overige

* operaties medicatie : medicatie :

2. Algemene anamnese

* datum

* tr. circulatorius medicatie

* hypertensie medicatie

* tr. respiratorius :
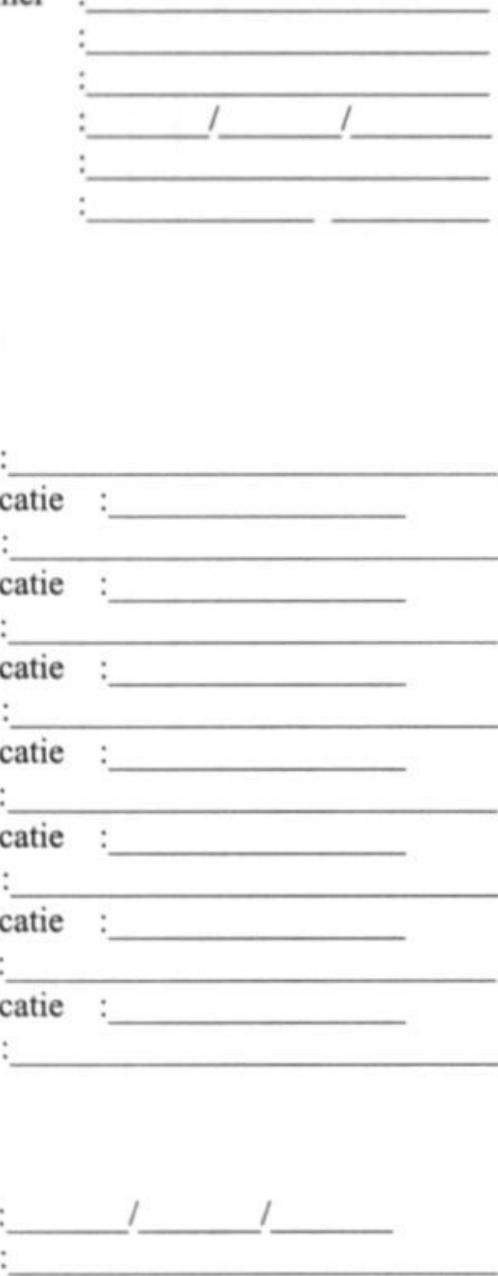
* tr. urogenitalis :

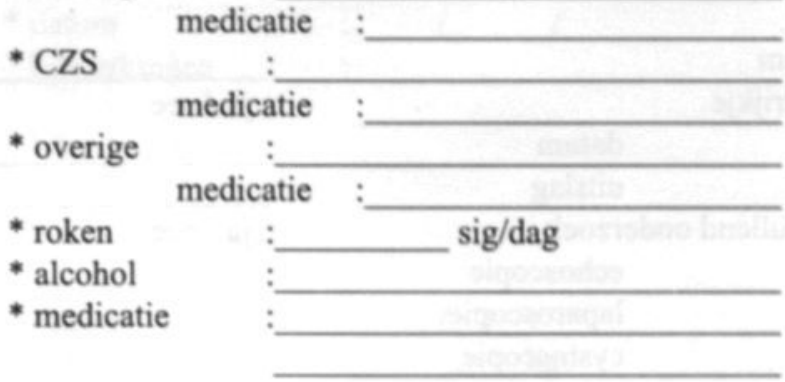

\section{Obstetrische en gynaecologische anamnese}

1. Obstetrische anamnese:
* datum
* gravida
* para
* abortus/mola

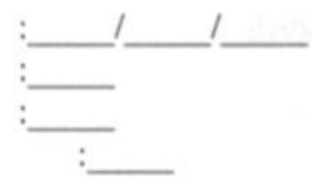

2. Gynaecologische anamnese:

* datum

* maligniteit

lokatie diagnose

* menarche therapie

* cyclus premenopauzaal

* menopauze

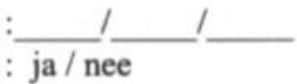

* huidige klacht

bloedverlies

fluor therapie:

pruritus

therapie:

pijn

therapie :

endocrinologie :

therapie :

* begin huidige klacht

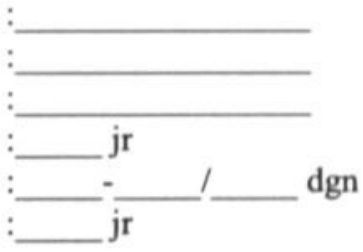

1




\section{Gynaecologisch onderzoek}

* datum

* uitstrijkje

datum
uitslag

*aanvullend onderzoek

echoscopie

laparoscopie

cystoscopie

rectosigmoidoscopie

overige

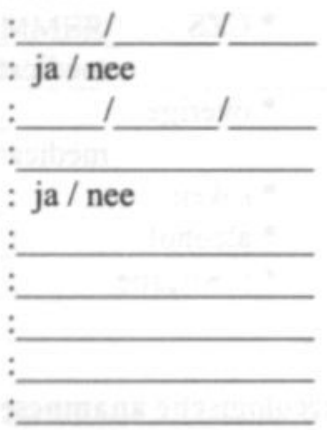

\section{Pre-operatief onderzoek}

1. Lichamelijk onderzoek:

* datum

* lengte

* gewicht

* bloeddruk

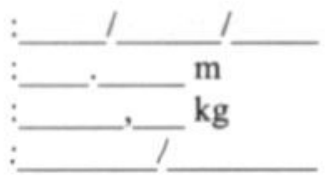

2. Bloedonderzoek:
${ }^{*} \mathrm{Hb}$
${ }^{*} \mathrm{Ht}$
* BSE
* Alat
* Kreat
* Kalium

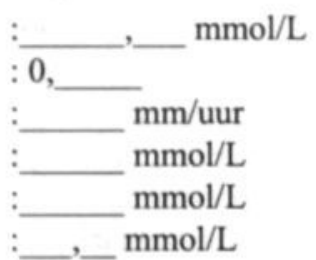

3. Urineonderzoek:

4. ECG:

5. X-thorax:

\section{Bevindingen per- en postoperatief}

1. Curettage:

$$
\begin{aligned}
& { }^{*} \text { datum } \\
& { }^{*} \text { sondelengte } \\
& { }^{*} \text { cervixcurettage } \\
& { }^{*} \text { corpuscurettage } \\
& \text { * cavum } \\
& \text { *PA }
\end{aligned}
$$

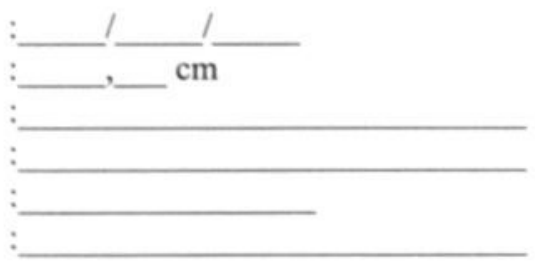


2. Decapeptyl:

* datum

* bijwerkingen

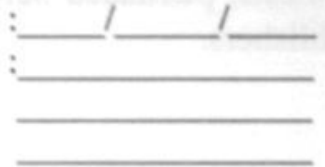

3. Operatie:

* datum

* gewicht

* soort operatie

* cytologie buikvocht

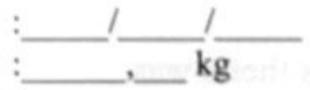

$: \mathrm{ja} / \mathrm{nee}$

* complicaties

ja / nee

bloedverlies

laesies

:

:

4. Postoperatief:

$\begin{array}{ll}\text { * complicaties } & : \mathrm{ja} / \mathrm{nee} \\ \text { infecties } & \\ \text { haematoom/nabloed. } & \\ \text { trombo-embolieën } & \\ \text { wonddehiscentie } & \\ \text { overige } & \\ \text { * gewicht na } 6 \text { weken } & \end{array}$


All chapters in this thesis, published before in a medical journal, are reprinted with permission of the publishers.

The publication of this thesis was

financially supported by:

- Abbott B.V.

- Ferring Nederland B.V.

- Janssen-Cilag B.V.

- Novo Nordisk Farma B.V.

- Organon Nederland B.V.

- Schering Nederland B.V.

- Solvay Pharma

- Zeneca Farma 

